\title{
MANEJO DA FERTIRRIGAÇÃO E CONTROLE DA SALINIDADE EM SOLO CULTIVADO COM MELÃO RENDILHADO SOB AMBIENTE PROTEGIDO
}

\author{
NILDO DA SILVA DIAS
}

Tese apresentada à Escola Superior de Agricultura "Luiz de Queiroz", Universidade de São Paulo, para obtenção do título de Doutor em Agronomia, Área de Concentração: Irrigação e Drenagem.

PIRACICABA

Estado de São Paulo - Brasil

Maio - 2004 


\title{
MANEJO DA FERTIRRIGAÇÃO E CONTROLE DA SALINIDADE EM SOLO CULTIVADO COM MELÃO RENDILHADO SOB AMBIENTE PROTEGIDO
}

\author{
NILDO DA SILVA DIAS \\ Engenheiro Agrônomo
}

Orientador: Prof. Dr. SERGIO NASCIMENTO DUARTE

Tese apresentada à Escola Superior de Agricultura "Luiz de Queiroz", Universidade de São Paulo, para obtenção do título de Doutor em Agronomia, Área de Concentração: Irrigação e Drenagem.

P I R A C I C A B A

Estado de São Paulo - Brasil

Maio - 2004 


\section{Dados Internacionais de Catalogação na Publicação (CIP) DIVISÃO DE BIBLIOTECA E DOCUMENTAÇÃO - ESALQ/USP}

Dias, Nildo da Silva

Manejo da fertirrigação e controle da salinidade em solo cultivado com melão rendilhado em ambiente protegido / Nildo da Silva Dias. - - Piracicaba, 2004.

$110 \mathrm{p}$.

Tese (doutorado) - - Escola Superior de Agricultura Luiz de Queiroz, 2004.

Bibliografia.

1. Ambiente protegido (Planta) 2. Fertirrigação 3. Melão 4. Pós-colheita 5. Química do solo 6 . Salinidade do solo I. Título

CDD 635.61 
Com gratidão aos meus pais, Neusa e Manoel Dias.

Em homenagem a todos que contribuíram com a minha formação política, intelectual e humanista,

DEDICO

Às famílias brasileiras semterra, sem-teto, sem educação, sem esperança e, sobretudo, sem futuro, 
O poder é a maior tentação do ser humano, pois ele nos dá o sentimento da onipotência divina. Ele é vigor puro. E ficando só vigor, ele é destrutivo. Só a ternura limita o poder, fazendo com que ele seja benfazejo. Ternura e vigor são as duas dimensões básicas que constroem o ser humano bem realizado. $O$ equilíbrio entre ternura e vigor fez com que os grandes fossem grandes, como Gandhi, Chico Mendes, Betinho, Francisco de Assis e, não em último lugar, o homem de Nazaré.

Leonardo Boff. 


\section{AGRADECIMENTOS}

- A Deus, pela fé e perseverança concedida em todos os momentos;

- Ao meu orientador Sergio Nascimento Duarte, pelos anos de convívio, pelas excelentes discussões e sugestões e, sobretudo, pela amizade;

- Ao professor Hans Raj Gheyi, por acreditar no meu trabalho, pela sua atenção e disponibilidade, pois sempre que o procurei buscou auxiliar-me;

- Ao Dr. Ênio Farias de França e Silva, pela motivação e atenção logo que cheguei em Piracicaba;

- Aos professores Rubens Duarte Coelho e Antonio Boaretto pelas observações e sugestões feitas no exame de qualificação;

- À CAPES que viabilizou a minha participação no curso, fornecendo uma bolsa de doutorado e à FAPESP pelo financiamento desta pesquisa;

- À Escola Superior de Agricultura "Luiz de Queiroz", pelas condições oferecidas durante a realização deste trabalho;

- Ao Doutorando Candido Athayde Sobrinho pelo parecer fitossanitário;

- Ao professor José Francismar de Medeiros pela colaboração nas análises estatística;

- Aos professores que muito tenho respeito e admiração: Nilson de Souza Sathler, Paulo Leonel Libardi, Tarlei Botrel e José Antonio Frizzone;

- Aos funcionários do Departamento de Engenharia Rural-ESALQ;

- Aos colegas Tales Miler, Luiza Duenhas, Marcos Emanuel, Cláudio Ricardo e Ralini Mélo, pela revisão final deste trabalho; 
- A todos os meus amigos do Departamento de Irrigação e Drenagem, pelas dificuldades e vitórias que vivenciamos;

- Aos estagiários Roberto Takafumi e José Teles e aos companheiros Antonio Clarette, Marconi, Juan, Boanerges, José Alves e Luis Gonzaga, pela importante contribuição nos trabalhos de campo e laboratório;

- E, finalmente, a todos que, de uma forma ou de outra, contribuíram para a realização deste trabalho, meus agradecimentos. 


\section{SUMÁRIO}

LISTA DE FIGURAS

LISTA DE TABELAS................................................................................ xii

LISTA DE APÊNDICES....................................................................... xiv

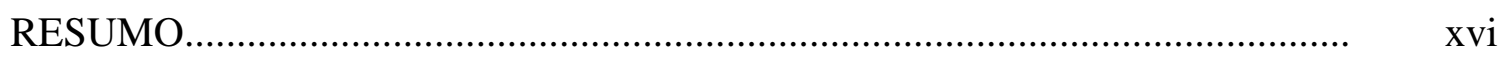

SUMMARY .................................................................................... $\quad$ Xviii

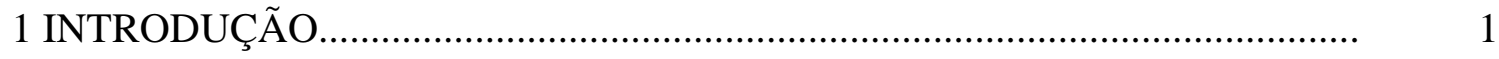

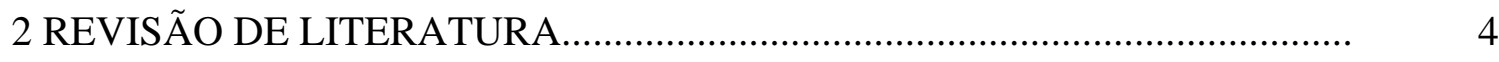

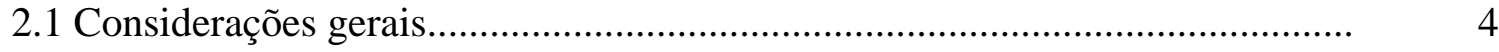

2.2 Características da cultura do melão............................................................. 6

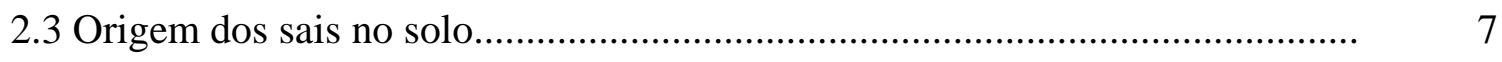

2.4 Efeito dos sais sobre as plantas............................................................. 9

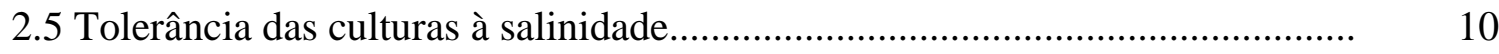

2.6 Salinidade integrada no espaço e no tempo.................................................... 12

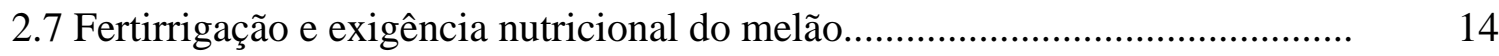

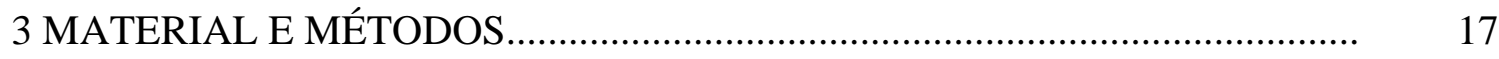

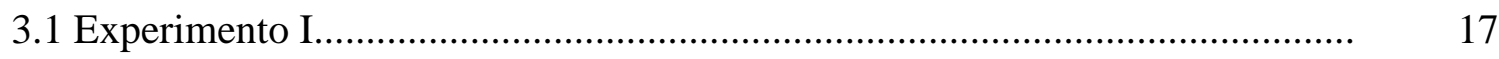

3.1.1 Construção das curvas de salinização artificial........................................... 17

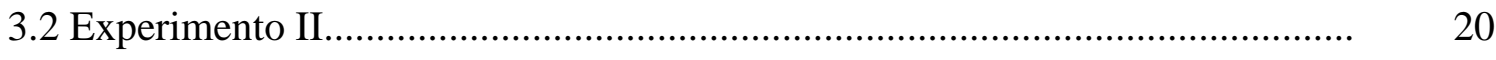

3.2.1 Localização e caracterização da área experimental...................................... 20

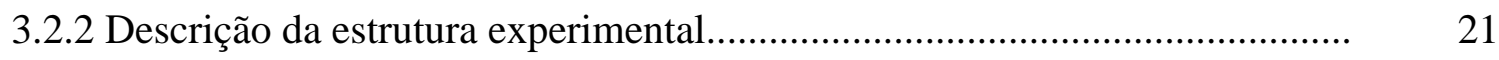

3.2.3 Tratamentos e delineamento experimental............................................. 21 
3.2.4 Condução do experimento II..................................................................... 24

3.2.5 Características avaliadas.............................................................................. 28

3.2.6 Análise estatística.......................................................................................... 32

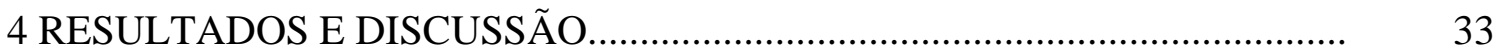

4.1 Experimento I - curvas de salinização artificial do solo....................................... 33

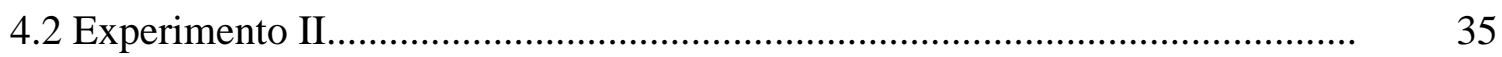

4.2.1 Salinização artificial do solo......................................................................... 35

4.2.2 Caracterização climática.............................................................................. 36

4.2.3 Monitoramento da salinidade do solo........................................................... 39

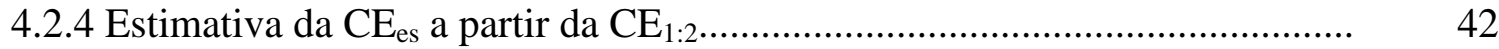

4.2.5 Análise química e correção da salinidade do solo............................................. 44

4.2.6 Evolução da salinidade do solo na zona radicular do meloeiro........................ 48

4.2.7 Potencial mátrico da água no solo.................................................................

4.2.8 Consumo de água sob estresse salino............................................................. 56

4.2.9 Crescimento de planta............................................................................. 59

4.2.10 Produção e componentes da produção............................................................. 73

4.2.11 Qualidade pós-colheita de frutos de meloeiro................................................ 78

4.2.12 Considerações finais e recomendações........................................................ 82

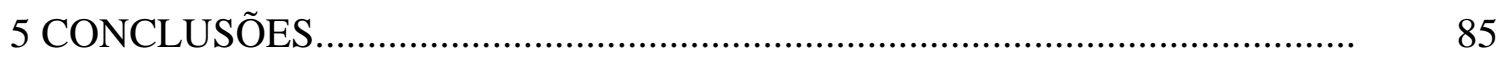

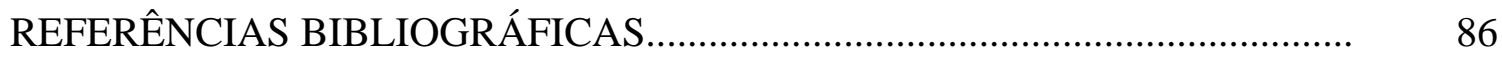

APÊNDICES ............................................................................................ 100 


\section{LISTA DE FIGURAS}

Página

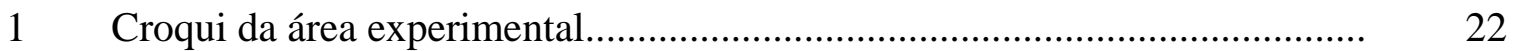

2 Disposição das parcelas experimentais: plantas de melão com 1 dia após o transplantio (DAT) (A) e 30 DAT (B).......................................................... 23

3 Construção das parcelas experimentais isoladas, utilizando-se divisões subterrâneas, com filme de polietileno (A) e detalhe da construção de uma

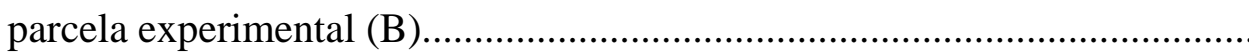

4 Detalhes das parcelas experimentais mostrando o controle da fertirrigação: manejo controlado com duas linhas de gotejadores (A) e manejo

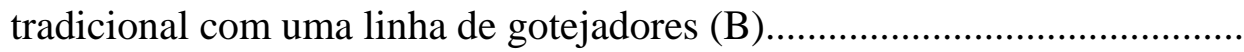

5 Eliminação do ar no interior do extrator com bomba de sucção (A) e com

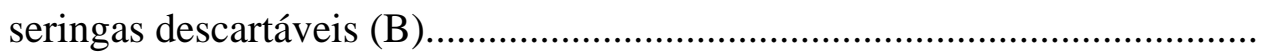

6 Tensiômetros instalados a 0,20 e 0,40 m e extrator, localizado opostamente ao tensiômetro, instalado a $0,2 \mathrm{~m}$...

7 Pontos de coleta das amostras de solo para determinar o perfil de distribuição de sais.

8 Relação entre a concentração das soluções de fertilizantes e a condutividade elétrica das soluções utilizadas (A) e relação entre a $\mathrm{CE}_{\text {es }}$ esperada e a $\mathrm{CE}_{\text {es }}$ obtida após a adição dos fertilizantes (B).

9 Curva de salinização artificial (relação entre a concentração de fertilizantes aplicada via água de irrigação e a $\mathrm{CE}_{\mathrm{es}}$ ) 
10 Valores médios de CE medidos no extrato de saturação do solo, em dS m ${ }^{-1}$, após a salinização artificial e após a correção para os diferentes

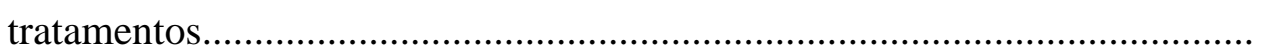

11 Variação das temperaturas do ar (máxima, mínima e média) e umidade relativa média no interior do ambiente protegido ao longo do primeiro (A) e segundo (B) ciclo da cultura do meloeiro.

12 Radiação solar global (Rsg) e líquida (Rsl) ao longo do primeiro (A) e do segundo (B) ciclo da cultura do meloeiro em condições protegidas.

13 Relação entre os valores de $\mathrm{CE}_{\mathrm{es}}$ medida e estimada a partir da $\mathrm{CE}_{\mathrm{s}}$ obtida com extratores de cápsula porosa, com correção em função da umidade......

14 Valores de condutividade elétrica do extrato de saturação do solo, estimados a partir dos valores medidos na solução obtida por extratores, ao longo dos dois ciclos do meloeiro, para os dois manejos da fertirrigação propostos: manejo tradicional-M $\mathrm{M}_{1}$ (A) e manejo controlado- $\mathrm{M}_{2}$ (B)

15 Relação entre a $\mathrm{CE}_{\mathrm{es}}$ e $\mathrm{CE}_{1: 2}(\mathrm{~A})$ e a relação entre os valores $\mathrm{CE}_{\mathrm{es}}$, medidos e estimados a partir $\mathrm{CE}_{1: 2}$, com correção em função da umidade de cada método (B), para o solo estudado.

16 Quantidade de Nitrogênio (N), Fósforo (P), Potássio (K), Cálcio (Ca) e Magnésio (Mg) aplicados nas irrigações nas diferentes fases de desenvolvimento para o manejo tradicional e para os diferentes níveis de salinidade do manejo controlado da fertirrigação ao longo do primeiro ciclo.

17 Quantidade de Nitrogênio (N), Fósforo (P), Potássio (K), Cálcio (Ca) e Magnésio (Mg) aplicados nas irrigações nas diferentes fases de desenvolvimento para o manejo tradicional e para os diferentes níveis de salinidade do manejo controlado da fertirrigação ao longo do segundo ciclo 47

18 Perfis transversais de salinidade do solo, medidos aos 60 DAT do $1^{\circ}$ ciclo para os tratamentos: $S_{1} M_{1}(A), S_{1} M_{2}(B), S_{3} M_{1}(C), S_{3} M_{2}$ (D), $S_{6} M_{1}$ (E), $\mathrm{S}_{6} \mathrm{M}_{2}(\mathrm{~F})$ 
19 Perfis transversais de salinidade do solo, medidos aos 60 DAT do $2^{\circ}$ ciclo para os tratamentos: $S_{1} M_{1}(A), S_{1} M_{2}(B), S_{3} M_{1}(C), S_{3} M_{2}$ (D), $S_{6} M_{1}$ (E), $\mathrm{S}_{6} \mathrm{M}_{2}(\mathrm{~F})$

20 Módulo do potencial mátrico, ao longo do $1^{\circ}$ ciclo, na profundidade de 20 cm para os tratamentos: $\mathrm{S}_{1} \mathrm{M}_{1}(\mathrm{~A}), \mathrm{S}_{1} \mathrm{M}_{2}(\mathrm{~B}), \mathrm{S}_{2} \mathrm{M}_{1}(\mathrm{C}), \mathrm{S}_{2} \mathrm{M}_{2}$ (D), $\mathrm{S}_{3} \mathrm{M}_{1}$ $(E), S_{3} M_{2}(F), S_{4} M_{1}(G)$ e $S_{4} M_{2}(H), S_{5} M_{1}(I), S_{5} M_{2}(J), S_{6} M_{1}(L)$ e $S_{6} M_{2}$ (M)

21 Módulo do potencial mátrico, ao longo do $2^{\circ}$ ciclo, na profundidade de 20 cm para os tratamentos: $S_{1} M_{1}(A), S_{1} M_{2}$ (B), $S_{2} M_{1}$ (C), $S_{2} M_{2}$ (D), $S_{3} M_{1}$ (E), $S_{3} M_{2}(F), S_{4} M_{1}(G)$ e $S_{4} M_{2}(H), S_{5} M_{1}(I), S_{5} M_{2}(J), S_{6} M_{1}(L)$ e $S_{6} M_{2}$ (M)

22 Lâmina de água acumulada aplicada com irrigação durante o primeiro ciclo da cultura do melão para o manejo tradicional - $\mathrm{M}_{1}$ (A) e manejo controlado - $\mathrm{M}_{2}$ (B) da fertirrigação.

23 Lâmina diária de água aplicada com irrigação durante o segundo ciclo da cultura do melão para o manejo tradicional - $\mathrm{M}_{1}(\mathrm{~A})$ e manejo controlado $\mathrm{M}_{2}$ (B) da fertirrigação.

24 Lâmina de água aplicada com irrigação em função dos níveis de salinidade para o primeiro (A) e segundo (B) ciclo......

25 Altura média de plantas ao longo do primeiro (A) e segundo (B) ciclo da cultura, para os diferentes níveis iniciais de salinidade do solo.

26 Diagrama de dispersão e equação de ajuste entre a altura de plantas e os níveis de salinidade inicial do solo para o $2^{\circ}$ ciclo do meloeiro aos 19 e 27 DAT (A), aos 34 e 42 DAT (B), aos 48 e 42 DAT (C) e aos 62 e 69 DAT (D).

27 Diagrama de dispersão e equação de ajuste entre a altura de plantas e os níveis de salinidade inicial do solo para o $1^{\circ}$ ciclo do meloeiro aos 17 e 28 DAT (A), aos 34 e 39 (B), aos 43 e 45 DAT (C) e aos 50 e 59 DAT (D) .... 63

28 Sintomas detectados em folhas de plantas cultivadas em níveis elevados de salinidade $\left(\mathrm{CE}_{\mathrm{es}}=6 \mathrm{dS} \mathrm{\textrm {m } ^ { - 1 }}\right)$ causada por excesso de fertilizantes. 
29 Diâmetro de colo ao longo do primeiro (A) e do segundo (B) ciclo da cultura para os diferentes níveis iniciais de salinidade do solo............................ 66

30 Diagrama de dispersão e equação de ajuste entre o diâmetro do colo e os níveis de salinidade inicial do solo para o primeiro ciclo do meloeiro aos 27 e 34 DAT (A), aos 42 e 48 DAT (B), aos 55 e 62 DAT (C) e aos 69 DAT (D)

31 Diagrama de dispersão e equação de ajuste entre o diâmetro do colo e os níveis de salinidade inicial do solo: para o segundo ciclo do meloeiro aos 28 e 34 DAT (A), aos 39 e 43 DAT (B), 45 e 50 DAT (C) e 59 DAT (D)........ 69

32 Variação do crescimento de área foliar nas diferentes fases de desenvolvimento para o primeiro (A) e o segundo (B) ciclo da cultura do meloeiro.

33 Diagrama de dispersão e equação de ajuste entre a área foliar e os níveis de salinidade inicial do solo para o primeiro ciclo do meloeiro aos 34 e 57 DAT (A) e aos 78 e 92 DAT (B)

34 Diagrama de dispersão e equação de ajuste entre o rendimento total (A), rendimento comercial (B), peso médio de frutos total (C) e peso médio de fruto comercial (C), para os dois ciclos em função dos níveis de salinidade inicial do solo.

35 Diagrama de dispersão e equação de ajuste entre o conteúdo de sólidos solúveis totais (A) e pH (B) para os dois ciclos, em função dos níveis de salinidade inicial do solo 


\section{LISTA DE TABELAS}

1 Caracterização química do solo.......................................................... 19

2 Características físico-hídricas do solo................................................... 19

3 Resumo da análise de variância para altura de plantas ao longo do primeiro ciclo do meloeiro, em função dos níveis de salinidade e manejo da fertirrigação........................................................................ 6

4 Resumo da análise de variância para altura de plantas ao longo do segundo ciclo do meloeiro, em função dos níveis de salinidade e manejo da fertirrigação....................................................................... 6

5 Resumo da análise de variância para o diâmetro de colo ao longo do primeiro ciclo do meloeiro, em função dos níveis de salinidade e manejo da fertirrigação

6 Resumo da análise de variância para o diâmetro de colo ao longo do segundo ciclo do meloeiro, em função dos níveis de salinidade e manejo da fertirrigação

7 Resumo da análise de variância para a área foliar ao longo dos dois ciclos consecutivos do meloeiro, em função dos níveis de salinidade e do manejo da fertirrigação

8 Resumo da análise de variância para acúmulo de fitomassa medido no final do primeiro ciclo do meloeiro, em função dos níveis de salinidade e manejo da fertirrigação 
9 Resumo da análise de variância e médias do rendimento total (RT), rendimento comercial (RC), peso médio de fruto total (PMFT) e peso médio de fruto comercial (PMFC) para os dois ciclos consecutivos do meloeiro, em função dos níveis de salinidade e dos manejos da fertirrigação............................................................... 75

10 Resumo da análise de variância e médias do teor de sólido solúvel total (SST), pH e acidez total titulável (ATT) em frutos de meloeiro, para os dois ciclos consecutivos, em função dos níveis de salinidade e manejo da fertirrigação.................................................................

11 Resumo da análise de variância e médias da firmeza de polpa, espessura da casca e espessura da polpa em frutos de meloeiro, para o segundo ciclos, em função dos níveis de salinidade e do manejo da fertirrigação................................................................................ 


\section{LISTA DE APÊNDICES}

Página

1 Tipos e quantidade de sais aplicados ao solo para obter os níveis de salinidade desejados...................................................................... 101

2 Parecer Fitossanitário.................................................................... 102

3 Quantidade de nutrientes $\left(\mathrm{g} \mathrm{planta}^{-1}\right.$ ) aplicados nas irrigações para o manejo tradicional e os diferentes níveis de salinidade do manejo controlado da fertirrigação ao longo do primeiro ciclo............................ 104

4 Quantidade de nutrientes (g planta ${ }^{-1}$ ) aplicados nas irrigações para o manejo tradicional e os diferentes níveis de salinidade do manejo controlado da fertirrigação ao longo do segundo ciclo............................. 105

5 Caracterização química do solo após a salinização artificial do solo realizada, no início do transplantio do melão......................................... 106

6 Caracterização química do solo aos 60 DAT do primeiro ciclo na camada

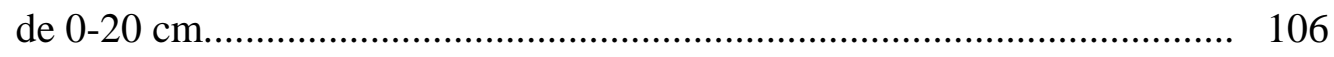

7 Caracterização química do solo aos 90 DAT do primeiro ciclo na camada

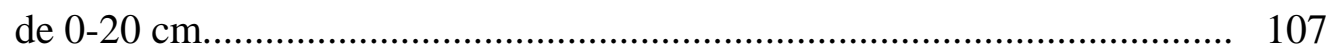

8 Caracterização química do solo aos 10 DAT do segundo ciclo na camada

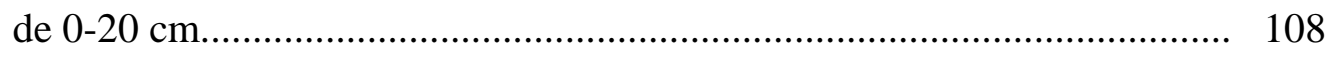


9 Caracterização química do solo aos 45 DAT do segundo ciclo na camada de $0-20 \mathrm{~cm}$............................................................................. 108

10 Caracterização química do solo aos 90 DAT do segundo ciclo na camada

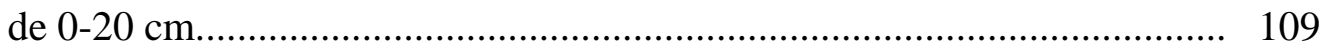

11 Lâmina média diária e acumulada de água aplicada, por época de aplicação para os diferentes níveis de salinidade e manejo da fertirrigação durante o primeiro ciclo..................................................... 110

12 Lâmina média diária e acumulada de água aplicada, por época de aplicação, para os diferentes níveis de salinidade e manejo da fertirrigação durante o segundo ciclo.................................................. 110 


\title{
MANEJO DA FERTIRRIGAÇÃO E CONTROLE DA SALINIDADE EM SOLO CULTIVADO COM MELÃO RENDILHADO SOB AMBIENTE PROTEGIDO
}

\author{
Autor: NILDO DA SILVA DIAS \\ Orientador: Prof. Dr. SERGIO NASCIMENTO DUARTE
}

\section{RESUMO}

Com o objetivo de avaliar o uso de extratores de soluções do solo no auxílio ao manejo da fertirrigação e no controle da salinidade em solo cultivado com melão rendilhado, conduziu-se um estudo em ambiente protegido na área experimental do Departamento de Engenharia Rural da ESALQ/USP, localizado no município de Piracicaba, SP. Os tratamentos foram compostos da combinação de dois fatores: 6 níveis de salinidade inicial do solo $\left(S_{1}=1,0 ; S_{2}=2,0 ; S_{3}=3,0 ; S_{4}=4,0 ; S_{5}=5,0\right.$ e $S_{6}=6,0$ dS $\mathrm{m}^{-1}$ ) e dois manejos de fertirrigação: tradicional e com controle da condutividade elétrica da solução do solo. O delineamento estatístico adotado foi o de blocos casualizados completos com 4 repetições, sendo os fatores estudados arranjados em um esquema fatorial de 6 x 2. A salinização inicial do solo se procedeu por meio da aplicação de soluções salinas preparadas a partir de fertilizantes, sendo que a quantidade de sais a ser adicionada foi determinada tomando por base uma curva de salinização artificial obtida previamente em laboratório. A condutividade elétrica da solução foi medida após o término de cada evento de irrigação, utilizando-se extratores com cápsulas porosas. 
Os resultados revelam que as produções total e comercial, além do peso médio total dos frutos foram significativamente reduzidos com o incremento dos níveis de salinidade do solo Os efeitos da salinidade do solo sobre a altura e o diâmetro das plantas foram mais severos durante o desenvolvimento vegetativo inicial do que no início da frutificação, o que sugere uma possível adaptação das plantas ao estresse salino ao longo do tempo. Embora não tenha sido possível se detectar diferenças expressivas causadas pelos dois tipos de manejo da fertirrigação no desenvolvimento ou na produção da cultura, o uso dos extratores de solução permitiu auxiliar no manejo da fertirrigação, mantendo os níveis desejados de salinidade da solução do solo ao longo do tempo. 


\title{
FERTIRRIGATION MANAGEMENT AND CONTROL OF THE SOIL SALINITY UNDER NETMELON CULTIVATION IN GREENHOUSE
}

\author{
Author: NILDO DA SILVA DIAS \\ Adviser: Prof. Dr. SERGIO NASCIMENTO DUARTE
}

\section{SUMMARY}

A study was carried out under greenhouse conditions, at the experimental area of the Department of Rural Engineering of "Escola Superior de Agricultura Luiz de Queiroz-USP”, Piracicaba, São Paulo State, Brazil, with the aim of evaluating ceramic cup samplers used to facilitate fertirrigation management and soil salinity control on a netmelon crop, was carried out The treatments comsisted of two combination factors: six level of initial soil salinity $\left(\mathrm{S}_{1}=1.0, \mathrm{~S}_{2}=2.0, \mathrm{~S}_{3}=3.0, \mathrm{~S}_{4}=4.0, \mathrm{~S}_{5}=5.0\right.$ and $\mathrm{S}_{6}=6.0 \mathrm{dS}$ $\mathrm{m}^{-1}$ ) and two fertirrigation managements: the traditional and the control of eletrical conductivity of soil solucion. The statiscal test was in randomized blocks, with four replications, arranged in $6 \times 2$ factorial design. The initial soil salinity value was obtained by appling saline solutions of fertilizer salts using an artificial soil salinization curve obtained previously in laboratory. The electrical conductivity in soil solucion was measured after each irrigation using ceramic cup samplers. Results showed that both total and marketable fruit yield and total weight per fruit were significantly reduced by increase in soil salinity level. The soil salinity effects on plants height and stem diameter 
were more severe during early vegetative growth than in the beginning of fruit set. This suggests a possible plant adaptation to saline stress along the time. Although no differences were observed in case fertirrigation management treatments on plants development or yield, however the use of solution extractors helped in fertirrigation management because them permitted to keep soil solution salinity at desired level. 


\section{INTRODUÇÃO}

Na última década, tem-se observando um aumento mundial no cultivo de melão em ambiente protegido. No Brasil, pode-se verificar tal ocorrência no Estado de São Paulo. Entretanto, o manejo inadequado da irrigação, a adição de fertilizantes em altas doses e a inexistência de chuvas promotoras de lixiviação do excesso de sais aplicados via água de irrigação podem trazer como conseqüência a salinização dos solos em ambientes protegidos, prejudicando o rendimento de culturas sensíveis, como por exemplo a cultura do melão.

Observa-se também, embora em pequena intensidade, que a salinização pode provir da utilização de águas salinas oriundas de poços. Na região de Piracicaba, por exemplo, segundo Oliveira \& Salati (1981), é comum a ocorrência de poços tubulares profundos com águas ricas em cloretos e sulfatos de sódio, com teores que podem propiciar uma condutividade elétrica (CE) às vezes superior a 3,0 dS m $\mathrm{m}^{-1}$ e com uma razão de adsorção de sódio capaz de causar toxidez devida à absorção excessiva deste cátion.

$\mathrm{Na}$ maioria dos casos, entretanto, o aumento da salinidade em ambientes protegidos no Estado de São Paulo se dá em função do excesso de fertilizantes aplicados via água de irrigação. Assim, a utilização de uma estratégia de controle da salinidade por intermédio da aplicação de lâminas de lixiviação, recomendada por vários autores, como Hoorn \& Alphen (1981), por exemplo, não seria a prática de manejo mais adequada, visto que os sais acumulados no solo, que seriam lixiviados, foram adquiridos por investimento de capital (Silva et al., 1999). 
Tradicionalmente, o manejo da fertirrigação é realizado ministrando-se quantidades pré-estabelecidas de fertilizantes, parceladas de acordo com a marcha de absorção da cultura, não existindo, normalmente, nem monitoramento da concentração de íons na solução do solo, nem do estado nutricional da planta (Papadopoulos, 1999). Neste aspecto, seria mais viável racionalizar o manejo da fertirrigação por meio da determinação da condutividade elétrica e/ou da concentração parcial de íons na solução do solo. Caso a condutividade elétrica da solução do solo apresente valores inferiores ao máximo tolerado pela cultura, sem decréscimo no rendimento relativo, e superiores ao mínimo necessário para sua nutrição, a salinização estaria controlada (Burgueño, 1996).

A identificação dos solos afetados por sais se baseia em uma série de observações e estudos da área, incluindo observação de características visuais de campo e realização de diversas análises, tanto por métodos de laboratório como por métodos de campo. No laboratório, a salinidade do solo pode ser estimada a partir de medidas de condutividade elétrica do extrato de saturação $\left(\mathrm{CE}_{\mathrm{es}}\right)$ ou da condutividade elétrica (CE) em diferentes relações solo : água destilada (Richards, 1954). Em campo, vários métodos são disponíveis para determinar a CE e avaliar a salinidade do solo, tais como técnica de indução eletromagnética, "four-electrodes probe”, "time domain reflectometry-TDR” (Rhoades, 1994) e ainda, mediante o uso de extratores de solução. Cada um desses métodos apresenta vantagens e desvantagens, sendo que o uso de extratores por cápsula porosa é atualmente um dos mais recomendados, em função da boa relação entre o custo e a precisão do método (Silva, 2002), e também devido ao fato de que a CE obtida por esse método reflete as condições reais em que a planta se desenvolve.

Estudos visando a definição da salinidade crítica no solo para as culturas exploradas, associados ao manejo da fertirrigação ao longo do ciclo cultural, são fundamentais para melhorar a produção, uma vez que se dispõe de poucas informações relacionadas ao efeito da salinidade do solo quando ocasionada por excesso de fertilizantes sobre o desenvolvimento e rendimento de olerícolas cultivadas em ambiente protegido. 
Desse modo, o presente trabalho teve como objetivo estudar os efeitos de diferentes níveis de salinização inicial do solo sobre o desenvolvimento vegetativo e no rendimento do melão rendilhado, bem como avaliar o uso de extratores de solução no auxílio ao manejo da fertirrigação e no monitoramento e controle da evolução da salinidade em solo sob condição protegida. Ao mesmo tempo, pretendeu-se comprovar as seguintes hipóteses correlatas:

a) A quantidade de fertilizantes aplicados é o fator direto responsável pela elevação da salinidade do solo em ambientes protegidos.

b) É possível determinar a condutividade elétrica da solução do solo de forma representativa com auxílio dos extratores de solução, permitindo melhor controle dos íons na solução do solo durante o ciclo da cultura, evitando a evolução da salinização secundária do solo.

c) $\mathrm{O}$ rendimento das culturas diminui à medida que cresce a salinidade na zona radicular acima da concentração limite tolerada pela planta. 


\section{REVISÃO DE LITERATURA}

\subsection{Considerações gerais}

O meloeiro é uma cultura exigente em temperaturas noturnas e diurnas elevadas durante todo o seu ciclo de cultivo. Altas temperaturas e baixa umidade do ar elevam consideravelmente o teor de açúcares nos melões, tornando-os mais saborosos e aromáticos, consistentes e com maior vida útil pós-colheita. Tais características justificam o sucesso da cultura em regiões de climas quentes, como a região Nordeste, especificamente no Estado do Rio Grande do Norte (Pedrosa, 1997).

Na região Noroeste do Estado de São Paulo, esta cultura vem sendo explorada sob condições protegidas, principalmente o meloeiro rendilhado (Cucumis melo L. var. reticulatus Naud.). Estas variedades competem de forma vantajosa por apresentar melhor paladar (12 ${ }^{\circ}$ Brix) em relação às demais variedades de melão amarelo cultivadas nos Estados do Nordeste, que chegam ao mercado paulista com preços inferiores em até 5 vezes aos dos frutos das variedades reticulatus produzidos em ambientes protegidos. Entretanto, o melão rendilhado apresenta baixa vida útil pós-colheita e menor resistência ao transporte (Sousa et al., 1998), se comparada ao melão amarelo. Apesar disso, seu valor agregado superior ao melão amarelo e a possibilidade de cultivos em pequenas áreas justifica seu cultivo próximo aos centros consumidores paulistas.

De acordo com Coelho et al. (2003), na região Nordeste, o melão rendilhado é comercializado a granel, em mercados próximos, devido à vida pós-colheita curta, de aproximadamente, sete dias. É possível produzir este tipo de melão na região Sudeste, também nas proximidades do mercado consumidor, em estádio de maturação ideal, ofertando, desta maneira, frutos de melhor qualidade. 
A partir da década de 90, com a consolidação do cultivo de hortaliças em ambiente protegido, o cultivo de melão rendilhado despontou, como opção rentável ao produtor na realização de rotação de culturas de ciclo curto, não tendo concorrentes no mercado e conseguindo boa cotação de preço (Maruyama, 1999).

O cultivo em ambiente protegido constitui um dos importantes instrumentos de desenvolvimento regional, pois gera empregos e renda, novas alternativas de exploração agrícola, aumento de produtividade e viabilização da agricultura como opção de investimento. De acordo com Stanghellini (1993), o cultivo em ambientes protegidos constitui uma das alternativas para garantir o aumento da produtividade das olerícolas, pois promove proteção contra chuvas, granizos e geadas, além de reduzir o ataque de pragas e o consumo de água aplicada na irrigação por produção unitária, chegando a uma economia de até $50 \%$.

O uso de fertilizantes em excesso via água de irrigação em cultivos de olerícolas sob condições protegidas tem elevado os níveis de salinidade do solo, chegando a ultrapassar os limites de tolerância das culturas, causando diminuição do rendimento. Desta forma, a prática da fertirrigação, embora contribua de maneira significativa para o aumento da produtividade, em determinadas situações, sobretudo em ambientes protegidos, pode resultar em acúmulo de sais no solo. O excesso de sais no solo reduz a disponibilidade de água para as plantas, além de trazer problemas como o efeito de íons tóxicos específicos sobre a fisiologia vegetal, a tal ponto de afetar seus rendimentos e a qualidade de sua produção.

Embora os solos salinizados apresentem diversos problemas para as plantas, estes podem ser aproveitados para várias finalidades, desde que se adote um manejo adequado do sistema solo-água-planta na área afetada (Rhoades et al.,1992). Segundo Silva (2002), em condições protegidas, o monitoramento da concentração de íons na solução do solo, em níveis nos quais a salinidade apresenta valores inferiores ao máximo tolerado pela cultura e superiores ao mínimo necessário para sua nutrição, torna-se uma opção ideal por ser mais econômica e menos agressiva ao meio ambiente, sendo capaz de controlar a salinização. 


\subsection{Características da cultura do melão}

O meloeiro (Cucumis melo L.) é uma olerícola originária da região central da Ásia e também da África, de onde teria sido levado para a Europa. Sua introdução no Brasil foi feita pelos imigrantes europeus e seu cultivo teve início em meados da década de 60 no Rio Grande do Sul. Até esse período, todo melão comercializado e consumido no Brasil era proveniente da Espanha. A partir da década de 60, a exploração da cultura tomou grande impulso, inicialmente no Estado de São Paulo, estendendo-se posteriormente para as regiões Norte e Nordeste, atingindo seu apogeu em termos de área plantada e de produção a partir de meados da década de 80 a meados da década de 90.

O melão tem se constituído em ótimo negócio para o Nordeste brasileiro. Após o avanço das explorações nos vales do São Francisco e Açu, e em Mossoró, o Brasil passou a se destacar no cenário internacional (Costa \& Pinto, 1977).

Uma grande diversidade de melões é cultivada por todo o mundo, mas, de acordo com Pedrosa (1997), apenas três variedades têm maior importância econômica. A primeira variedade é o melão do tipo Valenciano Amarelo (Cucumis melo var. inodorus) cujos frutos são esféricos, amarelos, com polpa esbranquiçada, apresentando ótima conservação pós-colheita. A segunda variedade é o melão tipo Caipira (Cucumis melo var. cantalupensis), cujos frutos geralmente apresentam gomos, com poupa de coloração laranja ou salmão, havendo entretanto problemas de conservação pós-colheita. A terceira variedade é o melão tipo rendilhado (Cucumis melo var. reticulatus), que apresenta como características marcantes um forte aroma, coloração da polpa variando entre o verde e o salmão, casca rendilhada e baixa conservação pós-colheita.

Conhecido na região Nordeste como melão japonês ou cantaloupe, o melão rendilhado caracteriza-se por apresentar plantas de porte rasteiro, caule herbáceo muito ramificado e que produz frutos de, aproximadamente, $900 \mathrm{~g}$, com casca rendilhada e superfície rugosa. Os frutos quando maduros, em diversas cultivares, desprendem-se facilmente das plantas (Coelho et al, 2003). 
Com relação aos tipos de melão cultivados, aproximadamente 70 \% do melão produzido no Brasil são, ainda, do grupo “Amarelo” (inodorus), em que fazem parte diversas cultivares e híbridos. Os outros 30 \% pertencem aos melões das variedades cantalupensis e reticulatus, que apesar de possuírem alto valor comercial, principalmente no mercado externo, apresentam cultivo ainda restrito, devido à limitada resistência dos frutos ao transporte e à má conservação pós-colheita.

A cultura é exigente em temperaturas altas, tanto no solo como no ar, sendo a cucurbitácea mais exigente com relação ao calor (Filgueira, 1982). O meloeiro é uma planta de crescimento rápido e seu desenvolvimento é afetado por vários fatores interligados como temperatura, umidade relativa, aeração do solo e número de horas de insolação; estes fatores podem limitar a produtividade do meloeiro.

\subsection{Origem dos sais no solo}

A origem dos problemas de salinidade se confunde com a própria formação do solo, que é um produto da intemperização das rochas, envolvendo processos físicos, químicos e biológicos, mediante a ação de fatores como clima, relevo, organismos vivos e o tempo. Durante a intemperização, os diversos constituintes das rochas são liberados na forma de compostos simples (Richards, 1954)

Os sais liberados durante o processo de intemperização das rochas, dependendo da geomorfologia da região, podem ser carreados para horizontes inferiores mediante percolação ou levados a lugares distantes por escoamento superficial, conforme as condições de relevo, fluxo de água, etc. No primeiro caso, os sais são depositados nas águas sub-superficiais podendo, por capilaridade, acumular-se na superfície do solo a medida em que a água for evaporada ou consumida pela planta; o segundo fenômeno é responsável pela deposição e acumulação de sais em rios, mares, açudes e lagoas. Em regiões úmidas, por se tratar de zonas com precipitações elevadas, os sais são lixiviados até a zona freática ou eliminados através das águas superficiais, com maior freqüência. Já em regiões de clima árido e semi-árido, por apresentarem déficit hídrico na maior parte do ano e, na maioria das vezes, os solos serem rasos ou apresentarem camadas impermeáveis, a água que contém sais fica sujeita aos processos de evaporação ou 
evapotranspiração, podendo atingir, com o tempo, níveis comprometedores para o crescimento e desenvolvimento das plantas (Pizarro, 1978; Richards, 1970).

Embora a fonte principal e direta de todos os sais presentes no solo seja a intemperização das rochas, são raros os exemplos em que esta fonte de sais tenha provocado diretamente problemas relacionados com a salinidade do solo. A salinização do solo por este fenômeno é denominada salinização primária (Richards, 1954).

Os problemas de salinidade têm sido também associados à água utilizada na irrigação, à drenagem deficiente e à presença de águas sub-superficiais ricas em sais solúveis a pouca profundidade. Nesses casos, ou seja, quando a salinização resultante é devida à ação antrópica, a mesma é conhecida como salinização secundária. Além disso, a salinização pode ser causada pela aplicação de fertilizantes, de forma excessiva e pouco parcelada ao longo do ciclo cultural, induzindo o sistema radicular ao estresse osmótico.

De acordo com Oliveira (1997), em alguns casos a salinização secundária é responsável por perdas irreparáveis na capacidade produtiva dos solos, tornando estéreis grandes extensões de terras cultivadas. Assim, águas de qualidade duvidosa (com elevados riscos de salinidade e sodicidade), adubos com elevado índice salino (cloreto de potássio, nitrato de sódio e nitrato de amônio), drenagem ineficiente, dentre outros fatores, podem acelerar o processo de salinização secundária.

Silva (2002) atribui à fertirrigação com elevados índices salinos, aplicada em excesso para a nutrição das plantas, uma das principais causas da salinização em ambientes protegidos. Dias (2001), estudando a evolução da salinidade de um Luvissolo Crômico cultivado com melão fertirrigado, observou, no período de maior exigência nutricional da cultura, incrementos de até $1,60 \mathrm{dS} \mathrm{m}^{-1}$ na salinidade da água de irrigação provenientes da adição de adubos; tal fato foi responsável, em parte, pela salinidade máxima do solo, observada aos 45 dias após a semeadura. Desse modo, pode-se inferir que mesmo quando se utilizada água com uma composição salina original média, a salinidade induzida pelo uso de fertilizantes pode se estabelecer.

Outro fator importante que também deve ser levado em consideração, segundo Villas Bôas et al. (1994), é que em cultivo fertirrigado o processo de salinização pode 
ser acelerado quando se utilizam fertilizantes com maior poder de salinização, medidos pelo seu índice salino global e parcial. O índice global representa de forma relativa o poder de salinização dos fertilizantes, em que se atribui índice 100 ao nitrato de sódio e para os demais fertilizantes se atribui índice relativo a este; já o índice parcial considera o índice salino por unidade de nutrientes, e este é obtido pela razão entre o índice global e a porcentagem de nutriente fornecido pelo adubo.

\subsection{Efeito dos sais sobre as plantas}

As culturas sensíveis à salinidade sofrem redução progressiva do crescimento e da produção à medida que a concentração salina aumenta. De acordo com Lima (1997), os efeitos da acumulação excessiva dos sais solúveis sobre as plantas podem ser causados pelas dificuldades de absorção de água, toxicidade de íons específicos e pela interferência dos sais nos processos fisiológicos (efeitos indiretos), reduzindo o crescimento das plantas.

Conforme Medeiros (1992), o excesso de sais solúveis na solução do solo prejudica o desenvolvimento das plantas devido à diminuição do potencial osmótico, que juntamente com o potencial mátrico, representam as resistências que as raízes das plantas têm que vencer para absorver água do solo. Para estes autores, o aumento da pressão osmótica pode atingir um valor em que as plantas não terão forças de sucção suficiente para superar esse potencial e, conseqüentemente, não conseguirão absorver água, mesmo em um solo aparentemente úmido, fenômeno conhecido por seca fisiológica.

Os efeitos de íons tóxicos acontecem quando as plantas absorvem os sais do solo, juntamente com a água, permitindo que haja toxidez na planta por excesso de íons absorvidos. Este excesso promove desbalanceamento e danos ao citoplasma, resultando em danos inicialmente na bordadura e no ápice das folhas, a partir de onde a planta perde, por transpiração, quase que tão somente água, havendo nestas regiões acúmulo do sal translocado do solo para a planta e, obviamente, intensa toxidez dos sais (Lima, 1997). 
Os danos devido à toxicidade podem reduzir significativamente o rendimento das culturas, estando sua magnitude dependente do tempo, da concentração de íons, da tolerância das plantas e do uso da água pelas culturas. Os problemas de toxicidade, freqüentemente, acompanham ou potencializam os de salinidade ou de permeabilidade, podendo surgir mesmo quando a salinidade for baixa. Os sintomas de toxicidade podem aparecer em qualquer cultura, desde que as concentrações de sais no interior da planta sejam suficientemente altas ou acima de seus níveis de tolerância (Ayers \& Westcot, 1991).

A toxicidade, normalmente, é provocada pelos íons cloreto, sódio e boro, entretanto, muitos outros oligoelementos são tóxicos para as plantas, mesmo em pequenas concentrações (Ayers \& Westcot, 1991). Santos (2000) relata que o mamoeiro é bastante sensível à presença de cloreto de sódio no solo, sendo a germinação de suas sementes e seu desenvolvimento inicial significativamente afetados com o aumento da concentração desse sal.

Os efeitos indiretos da salinidade usualmente ocorrem devido a concentração elevada de sódio ou outros cátions na solução, que interferem nas condições físicas do solo ou na disponibilidade de outros elementos, afetando o crescimento e o desenvolvimento das plantas indiretamente. Em muitos casos a concentração de sais não atinge níveis osmóticos capazes de prejudicar a absorção de água pelas plantas, no entanto, a concentração de íons diversos pode provocar interferências indiretas e ser um obstáculo à boa absorção de elementos essenciais e, conseqüentemente, ao desenvolvimento de um processo metabólico normal (Medeiros \& Gheyi, 1997).

\subsection{Tolerância das culturas à salinidade}

Várias práticas de manejo têm sido utilizadas para se produzir, economicamente, em condições de salinidade, dentre elas, destaca-se o uso de plantas tolerantes, sendo portanto importante os estudos que visem avaliar a sensibilidade das espécies ao estresse salino.

De acordo com Ayers \& Westcot (1991), nem todas as culturas respondem igualmente à salinidade; algumas produzem rendimentos economicamente aceitáveis sob 
níveis altos de salinidade, enquanto outras são sensíveis à níveis relativamente baixos. Tal fato se deve à melhor capacidade de adaptação osmótica de algumas plantas, capacidade esta que permite absorver, mesmo em meio salino, quantidade suficiente de água. Para esses autores, é muito útil essa variabilidade genética entre as espécies, permitindo a seleção das culturas mais tolerantes e capazes de produzir rendimentos economicamente aceitáveis, quando não se pode manter a salinidade do solo abaixo do nível de tolerância das plantas tradicionalmente cultivadas. A amplitude desta tolerância relativa permite maior uso das águas de qualidade inferior e aumento da faixa aceitável da salinidade do solo.

Segundo Medeiros (1998), a informação básica requerida para as decisões de manejo em solos afetados por sais inclui saber como as culturas respondem à salinidade, aos íons tóxicos, além de conhecer o efeito dos sais na infiltração da água no solo.

Os valores de tolerância das culturas encontrados na literatura se referem aos níveis de salinidade ocasionados pelo uso de água. Deve-se ressaltar que a curva típica, que relaciona o rendimento relativo com níveis crescentes de salinidade no solo ocasionados por excesso de fertilizantes, não apresenta o mesmo comportamento daquelas determinadas para a de salinização do solo com sais provindos de água de irrigação. Esta observação se deve ao fato de que um pequeno incremento de fertilizantes no solo pode acarretar em um consumo de luxo de nutrientes pela cultura e conseqüente aumento de produtividade. Entretanto, a partir de certo nível, o potencial osmótico e os desequilíbrios nutricionais poderiam vir a reduzir os rendimentos.

O meloeiro apresenta uma grande variação no nível de tolerância à salinidade entre os cultivares. Em Israel, Nerson \& Paris (1984) verificaram que os cultivares Honey Dew e Rochet foram mais tolerantes do que Eshkolit Ha'Amaqim e Noy Amid. Para as cultivares americanas PMR 45, Hale’s Best e Top Mark, Shannon \& François (1978) encontraram salinidade limiar (SL) de 2,3 dS m${ }^{-1}$ e perda de rendimento relativo por aumento unitário de $\mathrm{CE}_{\mathrm{es}}$ (b) de 5,9 \% por dS m $\mathrm{m}^{-1}$. Conforme Meiri et al. (1981), para o híbrido Israeli da cultivar tipo Gália, em Israel, encontrou-se $\mathrm{SL}=6,8 \mathrm{dS} \mathrm{m} \mathrm{m}^{-1}$ e b $=10 \%$ por $\mathrm{dS} \mathrm{m}^{-1}$. Para as cultivares Gália e Top Mark, nos Estados Unidos foram obtidos SL = 2,0 dS m $\mathrm{m}^{-1}$ e $\mathrm{b}=14,3 \%$ por dS $\mathrm{m}^{-1}$ (Meiri et al., 1982). Ayers \& Westcot 
(1991) citam que o melão tem um valor de salinidade limiar expresso em termos de condutividade elétrica do extrato de saturação $\left(\mathrm{CE}_{\mathrm{es}}\right)$ de 2,2 dS mº rendimento decresce para $50 \%$ quando a salinidade no extrato é de 9,1 dS m $\mathrm{m}^{-1}$, sendo classificado como uma cultura moderadamente tolerante $\left(b=7,2 \%\right.$ por $\mathrm{dS} \mathrm{m}^{-1}$ ).

Estes limites de tolerância estão baseados no acúmulo de sais provenientes de irrigações com águas de qualidade inferior, sendo necessário, portanto, conhecer a salinidade limiar tolerada pela cultura quando a salinização é dada por excesso de fertilizantes, tal como a que ocorre quando se cultiva em ambientes protegidos.

O comportamento das plantas com relação à salinidade pode variar de acordo com o seu estádio de desenvolvimento, embora não esteja claro se isto é devido à susceptibilidade à salinidade em um determinado estádio de crescimento ou ao longo do período em que a planta ficou exposta ao substrato salino, ou ainda, à combinação destes fatores.

Maas \& Hoffman (1977) afirmam que, de maneira geral, a salinidade afeta negativamente as plantas em todos os estádios, sendo que em algumas culturas mais sensíveis isto pode variar dos primeiros estádios para os últimos. Entretanto, de acordo com Amor et al. (1999), a qualidade do fruto de melão em termos de conteúdo de sólidos solúveis totais foi melhorada com o incremento da salinidade da água de irrigação.

\subsection{Salinidade integrada no espaço e no tempo}

O acúmulo de sais nos solos sob irrigação em regiões áridas, semi-áridas e em condições protegidas é inevitável, uma vez que os sais não participam do processo de evaporação, ou seja, a água retorna à atmosfera e os sais permanecem no solo (Santos, 1997). Deste modo, os problemas de salinidade podem evoluir com o tempo, quando não se utilizam técnicas apropriadas de manejo da água de irrigação (Rhoades et al., 1992)

De acordo com Hoffman et al. (1992), a distribuição dos sais no solo não é uniforme no espaço e nem ao longo do tempo. A aplicação de resultados de pesquisas sobre a tolerância das culturas à salinidade requer conhecimentos à respeito da resposta das plantas à salinidade, variando com o tempo e a profundidade. Vários experimentos 
em campo têm sido conduzidos considerando que as plantas respondem à salinidade média na zona radicular durante a fase de crescimento.

Rhoades (1972) introduziu o conceito de salinidade média integrada da solução do solo, ao longo do ciclo da cultura, para considerar as variações da salinidade entre as irrigações. Ingvalson et al. (1976), estudando a correlação do rendimento de alfafa, obtida sob condições de salinidade na zona radicular não uniforme, para vários índices de salinidade, verificaram que o rendimento de alfafa foi melhor correlacionado com a salinidade média integrada no tempo e no espaço (profundidade).

Segundo Medeiros \& Gheyi (1997), na maioria dos trabalhos de campo, a avaliação da salinidade do solo é tipicamente medida no início e no final do ciclo da cultura, e seus valores são utilizados para determinar a salinidade média do solo. Em experimentos, a salinidade do solo é normalmente monitorada com maior freqüência; porém, torna-se difícil relacionar a resposta das culturas à salinidade do solo integrada no tempo, pois em algumas culturas, a sensibilidade varia com os diferentes estádios de desenvolvimento.

Bernstein \& Pearson (1954), ao compararem a influência de um nível constante de salinidade com níveis crescente e decrescente, em vários ciclos, porém mantendo o valor médio do potencial osmótico idêntico ao produzido pelo nível constante, concluíram que o pimentão respondeu à salinidade média do período, independente do fato de se variar ou não a salinidade durante o desenvolvimento da cultura, enquanto que o tomate foi mais afetado por períodos de alta salinidade. Neste caso, segundo Hoffman et al. (1992), a resposta à salinidade média do período é provavelmente uma estimativa razoável, a não ser que a salinidade durante o ciclo inclua valores menores e maiores do que a salinidade limiar da cultura, ou que existam valores de salinidade acima da faixa de resposta linear na curva de tolerância à salinidade.

Santos (1997), estudando os efeitos de níveis de salinidade de água e de lâminas de irrigação na evolução da salinidade do solo, concluiu que houve acúmulos de sais no solo, nas três profundidades estudadas, sendo diretamente proporcionais aos níveis de água de irrigação. Medeiros (1998), Blanco (1999), Silveira (1999) e Dias (2001), 
demonstraram que o que o acúmulo de sais é maior na camada superficial do solo, quando são feitas irrigações localizadas durante períodos curtos.

Segundo Ayers \& Westcot (1991), com fração de lixiviação entre 0,15 a 0,20 e padrão normal de extração (60, 30, 7 e 3 \% da água consumida pela cultura, extraída respectivamente da quarta parte superior à inferior da zona radicular), a salinidade média da água do solo na zona radicular após se atingir um equilíbrio é aproximadamente 2,8 vezes mais elevada que a salinidade da água de irrigação $\left(\mathrm{CE}_{\mathrm{a}}\right)$. A salinidade média da água contida na zona radicular $\left(\mathrm{CE}_{\mathrm{zr}}\right)$ é aquela que deve ser tolerada pelas plantas, porém é bastante difícil de ser medida diretamente. No entanto, uma das medidas de salinidade do solo é a condutividade elétrica do seu extrato de saturação $\left(\mathrm{CE}_{\mathrm{es}}\right)$, sendo para um solo de textura média, sua concentração aproximadamente igual a metade do valor da concentração da solução do solo, quando este se encontra na capacidade de campo. Deste modo, ao se atingir o equilíbrio, a salinidade do extrato de saturação do solo é aproximadamente igual a 1,4 vezes a salinidade da água de irrigação.

Assim como outras propriedades químicas e físicas do solo, a salinidade é uma propriedade bastante variável no espaço e no tempo, devido à natureza dinâmica do processo e as interações causadas pelos diversos fatores edáficos (permeabilidade do solo, nível do lençol freático, etc), climáticos (quantidade e distribuição de chuvas, umidade relativa, temperatura, etc) e ação do homem (irrigação, práticas culturais, etc). Desta forma, na definição de estratégias de manejo e no estabelecimento de planos de recuperação dos solos afetados por sais, o monitoramento espacial (e temporal) dos parâmetros que definem a salinidade constitui um aspecto de fundamental importância (Queiroz et al., 1997).

\subsection{Fertirrigação e exigência nutricional do melão}

A fertirrigação é uma técnica que consiste na aplicação simultânea de água e fertilizantes por meio de um sistema de irrigação (Frizzone et al., 1985). Seu uso é generalizado nos países onde a agricultura é desenvolvida, sendo considerada uma das principais práticas responsáveis pela obtenção de altas produtividades. 
De acordo com Goto et al. (2001), a fertirrigação por gotejamento é a forma de aplicação que mais se aproxima do ritmo de absorção de água e nutrientes pela planta. Esta técnica, quando utilizada adequadamente, contribui para o aumento da produtividade das culturas, melhora a eficiência do uso de fertilizantes, reduz as perdas de nutriente por lixiviação e controla a concentração de nutriente do solo. Além disso, torna-se uma técnica mais econômica em termos de fertilizantes, mão-de-obra e energia.

O meloeiro responde bem à fertirrigação, sendo esta prática é muito comum entre os produtores da região Nordeste brasileira. A aplicação de fertilizantes via água de irrigação em sistemas por gotejamento tem proporcionado produtividade média em torno de $30 \mathrm{Mg} \mathrm{ha}^{-1}$, enquanto que em sistemas convencionais esta é de apenas $15 \mathrm{Mg} \mathrm{ha}^{-1}$ (Pinto et al., 1996). Estudos realizados por Sousa et al. (1998) mostraram que a fertirrigação em meloeiro propiciou um bom desenvolvimento da cultura, obtendo-se produtividade comercial acima de 44,34 Mg ha-1 , com a aplicação de $160 \mathrm{~kg} \mathrm{ha}^{-1}$ de N e $190 \mathrm{~kg} \mathrm{ha}^{-1}$ de $\mathrm{K}_{2} \mathrm{O}$. O aumento da produtividade do meloeiro pode ser obtido com doses crescentes de nutrientes aplicados através da água de irrigação, contudo, precisa-se ajustar doses adequadas para a cultura em cada situação.

Embora o emprego da fertirrigação no Brasil já esteja consolidado em diversas regiões e em um grande número de espécies, seu principal problema está associado ao manejo incorreto desta técnica, devido à falta de informações adequadas e/ou utilização de forma empírica. A adoção rápida desta técnica em muitas regiões fez com que a prática se adiantasse à investigação e com isso apareceram os problemas. Infelizmente, este fato tem implicado em redução de produtividade e desestímulo ao uso da fertirrigação por parte de alguns produtores (Villas Bôas et al., 2001).

Os produtores que utilizam esta técnica fazem uso de fórmulas e procedimentos desenvolvidos por consultores e firmas de fertilizantes ou produtos agrícolas. Outro fator importante que também deve ser levado em consideração segundo Villas Bôas et al. (2001) é que o manejo inadequado da fertirrigação, além de reduzir a produtividade e a qualidade do produto por efeito de desequilíbrio nutricional, pode aumentar o custo de produção, ampliar a perda de água e de fertilizantes, causar a salinização dos solos 
devido à aplicação excessiva, e ainda, por meio de lixiviação, contaminar mananciais de águas, causando danos irreversíveis ao ambiente.

Montag \& Shnek (1998), alegando valores de produtividade normalmente maiores quando se utiliza a prática da fertirrigação, recomendam acréscimos nas doses dos adubos nitrogenados e potássicos em relação às doses recomendadas para adubação convencional. Também é muito comum, mediante os laudos laboratoriais, se recomendar as mesmas doses dos adubos, tanto para uso na adubação convencional quanto na fertirrigação. Provavelmente, essa recomendação não deve ser generalizada, pois, sendo os adubos aplicados em menor quantidades e maior freqüência, tem-se maior eficiência na fertirrigação.

Considerando inevitável a ocorrência de desequilíbrios nutricionais, em virtude da dificuldade de se quantificar com precisão os nutrientes absorvidos pela planta, e devido também a interferência inerente ao complexo de troca catiônica do sistema solo, estudos realizados por vários autores, como Silva (2002) por exemplo, propõem o monitoramento periódico da salinidade e de alguns nutrientes na solução do solo com auxílio dos extratores de solução e de testes rápidos.

O uso destes extratores auxilia no manejo da fertirrigação, permitindo identificar e contornar problemas causados por desequilíbrios nutricionais e processos de salinização. Segundo Burgueño ${ }^{1}$, citado por Silva (2002), ao se estabelecer o monitoramento periódico, a aplicação de fertilizantes pode ser controlada de forma a manter a concentração da solução do solo variando numa faixa de CE considerada adequada para a cultura, não sendo, portanto, necessário se aplicar lâminas de lavagem de manutenção, evitando, assim, desperdícios com água, energia e fertilizantes.

\footnotetext{
${ }^{1}$ BURGUEÑO, H. La fertirrigación en cultivos hortícolas com acolchado plástico. Culiacán: BURSAR, 1996. v.1, 45p.
} 


\section{MATERIAL E MÉTODOS}

O trabalho foi desenvolvido em duas etapas, sendo a primeira, denominada de Experimento I, realizada no Laboratório de Física do Solo do Departamento de Engenharia Rural, e a segunda, denominada Experimento II, conduzida em duas estufas plásticas.

O experimento I consistiu de testes preliminares que possibilitaram a construção de curvas de salinização artificiais, visando direcionar o processo de salinização artificial do solo necessário à realização do segundo experimento. O experimento II visou estudar os efeitos de diferentes níveis de salinidade inicial do solo, implementados por meio da aplicação de fertilizantes $\left(S_{1}=1,0 ; S_{2}=2,0 ; S_{3}=3,0 ; S_{4}=4,0 ; S_{5}=5,0\right.$ e $S_{6}$

$\left.=6,0 \mathrm{dS} \mathrm{m}{ }^{-1}\right)$ e dois manejos de fertirrigação $\left(\mathrm{M}_{1}=\right.$ tradicional e $\mathrm{M}_{2}=$ com controle da concentração iônica da solução do solo), no crescimento, desenvolvimento e rendimento do meloeiro.

\subsection{Experimento I}

\subsubsection{Construção das curvas de salinização artificial}

A primeira etapa do Experimento I foi conduzida no Laboratório de Física do Solo do Departamento de Engenharia Rural da Escola Superior de Agricultura "Luiz de Queiroz”, USP, no município de Piracicaba, SP. Esta etapa constou de ensaios que visaram obter curvas de condutividade elétrica em função da concentração de fertilizantes. As proporções, bem como os tipos de sais aplicados na água, seguiram aquelas correspondentes à extração total de nutrientes para a cultura do melão rendilhado, conforme informação relatada por Kano (2002). 
Para encontrar a relação entre a condutividade elétrica da solução $\left(\mathrm{CE}_{\mathrm{s}}\right)$ e os totais de sais dissolvidos, nas proporções desejadas de fertilizantes, utilizou-se inicialmente como referência a equação proposta por Richards (1954), apresentada na equação (1):

$$
\mathrm{C}=640 \mathrm{CE} \mathrm{S}_{\mathrm{S}}
$$

em que:

C = concentração de sais fertilizantes, $\mathrm{mg} \mathrm{L}^{-1}$;

$\mathrm{CE}_{\mathrm{s}}=$ condutividade elétrica da solução, $\mathrm{dS} \mathrm{m}^{-1}$.

Utilizaram-se diferentes soluções de concentrações conhecidas e preparadas a partir da diluição com água de abastecimento, em balões de $100 \mathrm{~mL}$, de um padrão de $6400 \mathrm{mg} \mathrm{L}^{-1}$, totalizando 21 soluções. A concentração dessas soluções variaram de 0,2 até $6400 \mathrm{mg} \mathrm{L}^{-1}$, com intervalos de $320 \mathrm{mg} \mathrm{L}^{-1}$, o que correspondeu, respectivamente, a salinidades teóricas variando de 0,2 até $10 \mathrm{dS} \mathrm{m} \mathrm{m}^{-1}$, com intervalos de $0,5 \mathrm{dS} \mathrm{m}^{-1}$, com base na equação (1). A amostra em branco $\left(0,2 \mathrm{mg} \mathrm{L}^{-1}\right)$ correspondeu à condutividade elétrica inicial da água de abastecimento sem a adição dos fertilizantes. A partir dessa preparação, determinou-se a condutividade elétrica real das soluções, utilizando-se um condutivímetro digital com leituras autocompensadas para a temperatura. A curva que relaciona a concentração dos fertilizantes e a condutividade elétrica das soluções foi estabelecida por meio de um diagrama de dispersão, onde foram plotados os valores da concentração de sais fertilizantes versus os da condutividade elétrica encontrada.

Na segunda etapa do Experimento I, foram coletadas amostras de $10 \mathrm{~kg}$ de solo, as quais foram peneiradas, secas ao ar e acondicionadas em vasos de $17 \mathrm{~L}$, tendo em sua base perfurada uma camada de $2 \mathrm{~cm}$ de brita, recoberta com manta geotextil (BIDIM OP-30), resultando em uma camada de solo de $20 \mathrm{~cm}$. O material de solo utilizado foi originado de um perfil classificado como Latossolo Vermelho fase arenosa, proveniente do campus da ESALQ e denominado Série "Sertãozinho”, do qual retiraram-se amostras 
da camada de 0-20 cm para as análises química (Tabela 1) e físico-hídricas (Tabela 2), realizada no Departamento de Solos e Nutrição de Plantas da ESALQ/USP.

Tabela 1. Caracterização química do solo

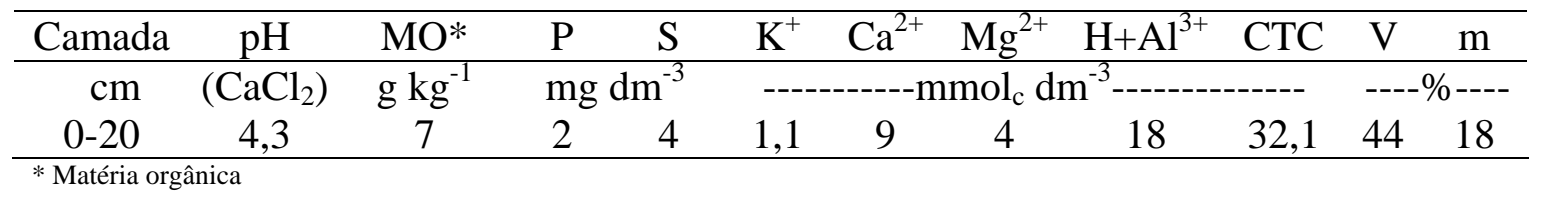

Tabela 2. Características físico-hídricas do solo

\begin{tabular}{|c|c|c|c|c|c|c|c|c|}
\hline \multirow{2}{*}{ Camada } & \multirow{2}{*}{ CC } & \multirow{2}{*}{ PMP } & \multirow{2}{*}{ Dg } & \multicolumn{3}{|c|}{ Frações granulométricas } & \multirow{2}{*}{ Floculação } & \multirow{2}{*}{ Textura } \\
\hline & & & & Argila & Silte & Areia & & \\
\hline $\mathrm{cm}$ & $\mathrm{cm}^{3} \mathrm{cr}$ & & $\mathrm{kg} \mathrm{dm}^{-3}$ & ------- & $\mathrm{g}^{-1}-$ & -- & $\%$ & \\
\hline $0-20$ & 0,213 & 0,137 & 1,4 & 280 & 80 & 640 & 100 & $\begin{array}{l}\text { Franco- } \\
\text { arenosa }\end{array}$ \\
\hline
\end{tabular}

A umidade do solo foi elevada até a máxima capacidade de retenção e concomitantemente foram adicionados os sais diluídos na água com o objetivo de obter 9 níveis de condutividade elétrica do extrato de saturação ( $\mathrm{CE}_{\mathrm{es}}: 1,0 ; 2,0 ; 3,0 ; 4,0 ; 5,0$; 6,0; 7,0; 8,0 e 9,0 dS m$~ m^{-1}$ ) com 3 repetições. O valor da concentração final de fertilizantes na água $\left(\mathrm{C}_{\mathrm{f}}\right)$ aplicada ao solo, necessário para se obter os níveis de $\mathrm{CE}_{\text {es }}$ desejados, foi estimado com base nos níveis e proporções utilizados na curva de salinização construída na etapa anterior e corrigidos pela umidade de saturação. O volume de água aplicado correspondeu ao necessário para elevar a umidade do solo nos vasos à máxima capacidade de retenção e as quantidades de sais adicionadas foram aquelas suficientes para se atingir os valores de $\mathrm{CE}_{\mathrm{es}}$ preconizados quando o solo estivesse saturado. Estimou-se a concentração final de fertilizantes utilizando a relação apresentada na equação (2):

$$
\mathrm{C}_{\mathrm{f}}=\frac{\mathrm{U}_{\mathrm{S}}}{\mathrm{U}_{\mathrm{CC}}} \mathrm{C}_{\mathrm{i}}
$$

em que: 
$\mathrm{C}_{\mathrm{f}}=$ concentração final de fertilizantes na solução salinizante, $\mathrm{mg} \mathrm{L}^{-1}$;

$\mathrm{C}_{\mathrm{i}}=$ concentração de fertilizantes com base na curva de salinização construída na etapa anterior, $\mathrm{mg} \mathrm{L}^{-1}$;

$\mathrm{U}_{\mathrm{s}}=$ Umidade da pasta saturada, $\mathrm{g} \mathrm{g}^{-1}$; e

$\mathrm{U}_{\mathrm{cc}}=$ Umidade do solo à capacidade de campo, $\mathrm{g} \mathrm{g}^{-1}$.

Dois dias após a adição das diferentes soluções salinas, foram retiradas amostras de solo dos vasos na camada de 0 a $20 \mathrm{~cm}$, após uma raspagem na qual se eliminou $2 \mathrm{~cm}$ da superfície do solo. A partir dessa amostragem determinou-se a condutividade elétrica do extrato de saturação real, ou seja, aquela que correspondeu aos valores encontrados no solo. A curva de salinização foi então construída, por meio de um diagrama de dispersão, onde foram plotados os valores de $\mathrm{CE}_{\text {es }}$ encontrados versus as quantidades de sais aplicadas.

O preparo da pasta de saturação consistiu na agitação de $300 \mathrm{~g}$ da amostra de solo com espátula, em recipiente plástico de $600 \mathrm{~mL}$, com adição gradual de água destilada, até que a mesma apresentasse as características desejadas, como superfície brilhosa, movimento lento em posição inclinada e fácil deslizamento sobre a espátula. Após o preparo da pasta, as amostras foram colocadas em repouso por 10 horas e em seguida retirado o extrato por sucção, determinando-se a $\mathrm{CE}_{\text {es }}$ por meio de condutivímetro, conforme a metodologia proposta por Richards (1954).

\subsection{Experimento II}

\subsubsection{Localização e caracterização da área experimental}

Este experimento foi conduzida em duas estufas plásticas do Departamento de Engenharia Rural da Escola Superior de Agricultura "Luiz de Queiroz"-USP, no município de Piracicaba-SP, situado nas coordenadas geográficas de $22^{\circ} 42^{\prime}$ de latitude sul e $47^{\circ} 38$ ' de longitude oeste, a uma altitude de $540 \mathrm{~m}$.

Segundo a classificação de Koppen, o clima da região é do tipo Cwa, isto é, tropical úmido, com 3 meses mais secos (junho, julho e agosto), ocorrendo chuvas de 
verão e secas de inverno, apresentando temperatura média do mês mais quente superior a $22{ }^{\circ} \mathrm{C}$ e do mês mais frio inferior a $18^{\circ} \mathrm{C}$ (Sentelhas, 1998).

\subsubsection{Descrição da estrutura experimental}

As duas estufas plásticas possuíam cobertura em arco, ambas com 6,40 m de largura e 22,5 m de comprimento, paredes laterais e frontais confeccionadas com telas antiafídeas e rodapé de 0,20 m em concreto armado, possuíam ainda cortinas laterais, as quais permitiam reduzir a variação de temperatura em seu interior e proteger contra chuvas e vento. A cobertura era constituída de manta de polietileno de baixa densidade, transparente, com 0,10 mm de espessura, tratada contra a ação de raios ultravioletas. Esta estrutura experimental era provida de energia elétrica e água potável oriunda do Sistema de Abastecimento de Água e Esgoto de Piracicaba (SEMAE), apresentando condutividade elétrica média de $0,3 \mathrm{dS} \mathrm{m}^{-1}$.

\subsubsection{Tratamentos e delineamento experimental}

Foram realizados avaliações com melão rendilhado (Cucumis melo L.), cultivar Bônus II, em dois ciclos, analisando-se os efeitos de diferentes níveis de salinidade inicial do solo no desenvolvimento vegetativo desta cultura. Além disso, procurou-se verificar a viabilidade do uso de extratores de solução no auxílio ao manejo da fertirrigação. Os tratamentos foram compostos da combinação de dois fatores: salinidade inicial do solo com, 6 níveis $\left(\mathrm{S}_{1}=1,0 \mathrm{dS} \mathrm{m}{ }^{-1} ; \mathrm{S}_{2}=2,0 \mathrm{dS} \mathrm{m}{ }^{-1} ; \mathrm{S}_{3}=3,0 \mathrm{dS} \mathrm{m}^{-1} ; \mathrm{S}_{4}=4,0\right.$

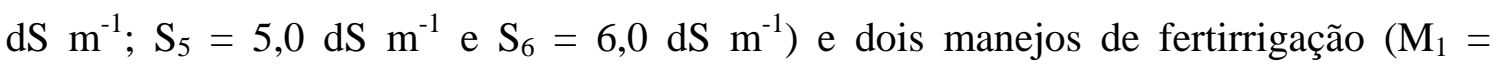
tradicional e $\mathrm{M}_{2}=$ com controle da concentração iônica da solução do solo). $\mathrm{O}$ delineamento estatístico adotado foi o de blocos casualizados completos com quatro repetições e os fatores estudados arranjados em esquema fatorial 6 x 2 .

Os tratamentos foram dispostos em 48 parcelas de 2,0 $\mathrm{m}^{2}(1,00 \times 2,00 \mathrm{~m})$, havendo 12 tratamentos com 4 repetições, dispostos conforme a Figura 1. Cada parcela era composta por uma fileira de plantas espaçada de 2,00 m, com 0,30 m entre plantas, totalizando 7 plantas por fileira, das quais, apenas as 5 plantas centrais foram consideradas úteis, sendo as demais plantas da parcela consideradas como bordadura 
(Figura 2). Os tratamentos foram isolados entre si, utilizando-se divisões subterrâneas, com 0,50 m de profundidade, constituídas de filme de polietileno, para evitar possíveis contaminações entre os tratamentos (Figura 3).

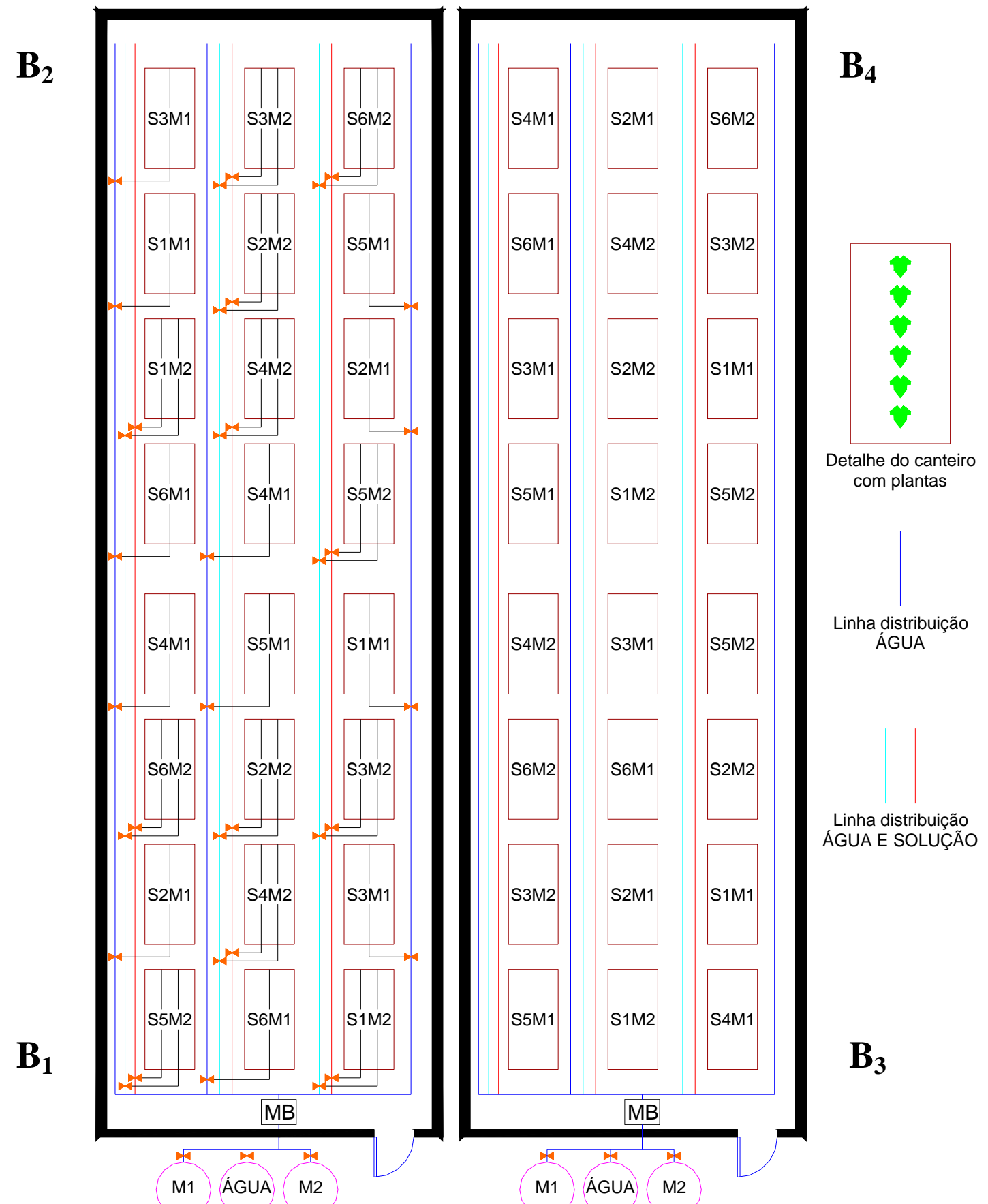

Figura 1 - Croqui da área experimental 

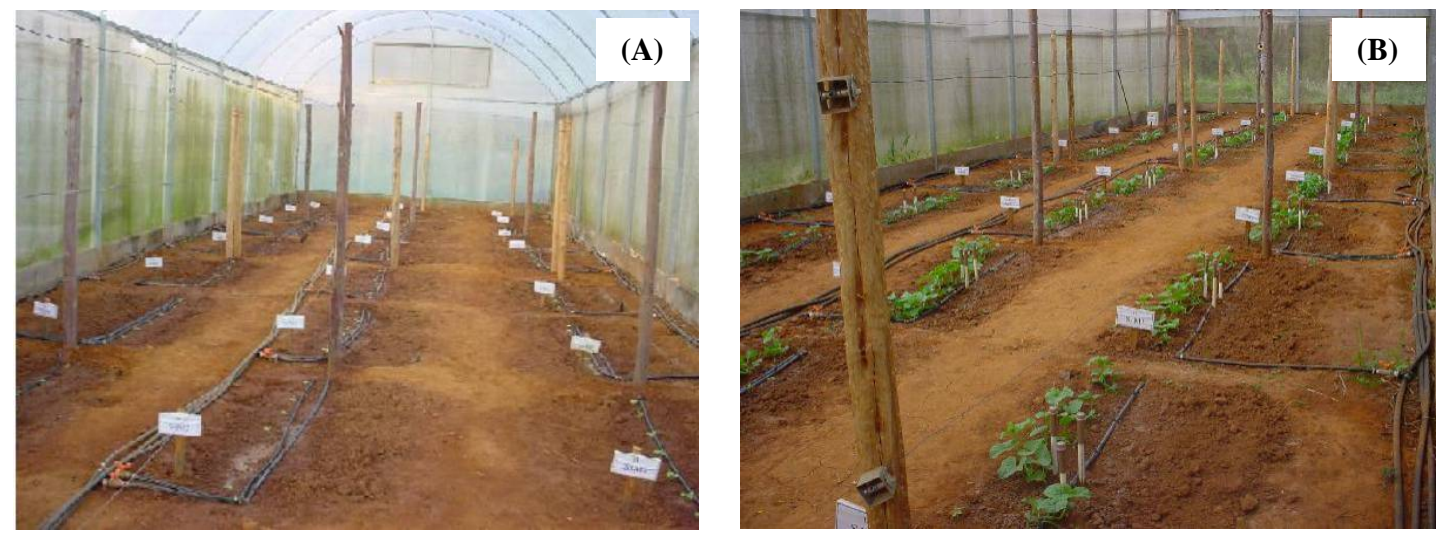

Figura 2 - Disposição das parcelas experimentais: plantas de melão com 1 dia após o transplantio (DAT) (A) e 30 DAT (B)
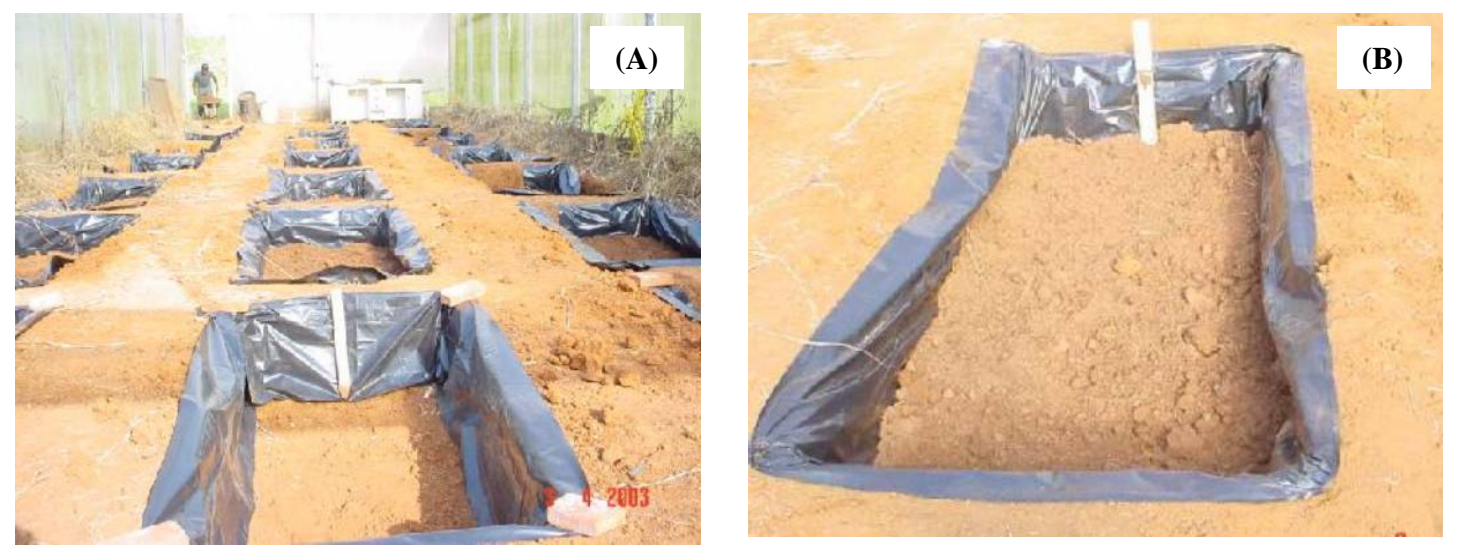

Figura 3 - Construção das parcelas experimentais isoladas, utilizando-se divisões subterrâneas, com filme de polietileno (A) e detalhe da construção de uma parcela experimental (B)

Os diferentes níveis de salinidade inicial do solo visam simular diversos estágios de salinização do solo em ambientes protegidos, possivelmente encontrados quando detectado o problema por parte dos agricultores. Estes níveis possibilitaram verificar os efeitos da salinidade na redução do crescimento, desenvolvimento, produção, qualidade e vida útil pós-colheita do meloeiro, além de permitir avaliar a eficiência do extrator de solução, associado ao segundo tipo de manejo de fertirrigação, $\mathrm{M}_{2}$, sobre o controle da salinização do solo em várias concentrações iônicas da solução. 
Os manejos de fertirrigação estudados, quais sejam, o tradicional, préestabelecido com base na marcha de absorção de nutrientes pela cultura $\left(M_{1}\right)$ e o corretivo, com base na concentração de íons na solução do solo $\left(\mathrm{M}_{2}\right)$, teve por objetivo avaliar o comportamento da disponibilidade e de concentrações tóxicas de nutrientes, bem como do processo de salinização do solo, possibilitando comparar os resultados obtidos pela metodologia proposta $\left(\mathrm{M}_{2}\right)$ com os obtidos na metodologia tradicional $\left(\mathrm{M}_{1}\right)$.

\subsubsection{Condução do experimento II}

\section{Salinização do solo}

A salinização do solo foi realizada por meio da aplicação de soluções salinas, sendo que, a quantidade de sais a ser adicionada foi determinada pela curva de salinização artificial obtida dos resultados do experimento I e a quantidade de água foi a necessária para elevar a umidade do solo à capacidade de campo (Apêndice 1). Após a adição da solução, foram retiradas amostras de solo para aferir a condutividade elétrica do extrato de saturação. Em seguida, foi adicionada uma nova solução salina de ajuste da condutividade elétrica da solução do solo, diferente da predeterminada, com base nos valores de $\mathrm{CE}_{\text {es }}$ obtidos, em que se aplicou uma correção no solo utilizado nas parcelas experimentais para obter-se o nível de salinidade média desejada. A referida correção foi calculada por meio de uma fórmula de mistura de soluções, a qual é apresentada na forma da equação (3):

$$
\mathrm{V}_{\mathrm{CC}} \mathrm{CE}_{\mathrm{esd}}=\mathrm{V}_{\mathrm{a}} \mathrm{CE}_{\mathrm{a}}+\mathrm{V}_{\mathrm{r}} \mathrm{CE}_{\mathrm{c}}
$$

em que:

$\mathrm{V}_{\mathrm{cc}}=$ Volume de água armazenado no solo à capacidade de campo, L;

$\mathrm{CE}_{\text {esd }}=$ Condutividade elétrica do extrato de saturação do solo desejada, $\mathrm{dS} \mathrm{m}^{-1}$;

$\mathrm{V}_{\mathrm{a}}=$ Volume atual de água armazenado no solo, $\mathrm{L}$;

$\mathrm{CE}_{\mathrm{a}}=$ Condutividade elétrica atual do solo, $\mathrm{dS} \mathrm{m}^{-1}$;

$\mathrm{V}_{\mathrm{r}}=$ Volume de água no solo necessário para se atingir a capacidade de campo, L;

$\mathrm{CE}_{\mathrm{C}}=$ Condutividade elétrica da solução de correção para se atingir a $\mathrm{CE}_{\mathrm{esd}}, \mathrm{dS} \mathrm{m}^{-1}$; 


\section{Plantio, condução das plantas e monitoramento climático}

Neste experimento foram realizados dois plantios consecutivos no mesmo par de estufas, sendo o primeiro transplantado no dia 05 de julho e o segundo em 03 de dezembro de 2003, com as colheitas perfazendo um ciclo de 117 e 94 dias, respectivamente. Vale salientar que entre o final do primeiro ciclo e o início do segundo foram transcorridos 35 dias. A cultura foi o melão (Cucumis melo L.) do tipo rendilhado, cultivar Bônus II. As mudas foram preparadas em bandejas de poliestireno de 128 células com substrato comercial organo-mineral, colocando-se uma semente por célula, sendo as mesmas transplantadas quando a segunda folha definitiva foi emitida, o que se deu aos 25 e 18 dias após a semeadura para o primeiro e o segundo ciclo, respectivamente.

O transplantio das mudas foi realizado em fileira única, no centro de cada parcela, utilizando-se espaçamento de 0,30 m entre plantas, correspondendo ao espaçamento do gotejador, a uma profundidade de aproximadamente $5 \mathrm{~cm}$.

A condução da cultura foi feita com espaldeiras verticais de $2 \mathrm{~m}$ de altura e fita de ráfia, eliminando-se os excessos de brotações laterais até o $9^{\circ}$ ramo, (entre 0,6 m a 0,7 m do colo da planta) por meios de podas, deixando os demais brotos com cinco folhas. Na poda, utilizou-se tesoura apropriada para cortes em hastes tenras, com posterior tratamento fitossanitário, evitando a entrada de patógenos pelos ferimentos. Após o raleio foram deixados 2 frutos por planta. Os frutos foram acondicionados em cestas plásticas (enredados), presos à linha de arame, para ajudar a sustentação nas plantas e conferir melhor qualidade de casca, permitindo bom desenvolvimento dos frutos selecionados (raleio) ao longo do ciclo da cultura.

O controle fitossanitário preventivo foi feito de 5 em 5 dias, utilizando produtos e doses adequadas às eventualidades. A polinização das plantas foi realizada colocando-se uma colméia de abelha no interior de cada estufa.

Para o monitoramento climático, instalou-se em uma das estufas, um sistema automático de aquisição de dados tipo CR $10 \mathrm{X}$ para registrar o sinal emitido pelos sensores dos elementos microclimáticos a cada 15 segundos e armazenar as médias a cada 30 minutos. Os sensores instalados foram: um piranômetro (radiação solar global) e 
um psicrômetro, com termopares de bulbo úmido e de bulbo seco (temperatura e umidade relativa). A radiação líquida foi estimada com base nos dados diários da radiação do ambiente externo, conforme regressão sugerida por Vásquez (2003).

\section{Manejo da irrigação}

Foi adotado um sistema de irrigação por gotejamento, utilizando emissores do tipo autocompensante, com vazão nominal de $4,0 \mathrm{~L} \mathrm{~h}^{-1}$, previamente avaliados em campo sob condições normais de operação, apresentando um coeficiente de variação de vazão de 6,33 \%, uniformidade de distribuição de 94,89 \% e vazão média real de 3,95 L $\mathrm{h}^{-1}$. Os gotejadores estavam acoplados às linhas de tubos de polietileno, no início das quais foram instalados registros, o que possibilitou aplicar o volume diferenciado de água. As parcelas com tratamentos $\mathrm{M}_{2}$ possuíam duas linhas de gotejadores, sendo uma para aplicar solução de fertirrigação e outra para aplicar só água quando a aplicação de fertilizantes não se fazia necessária, evitando possível contaminação (Figura 4).
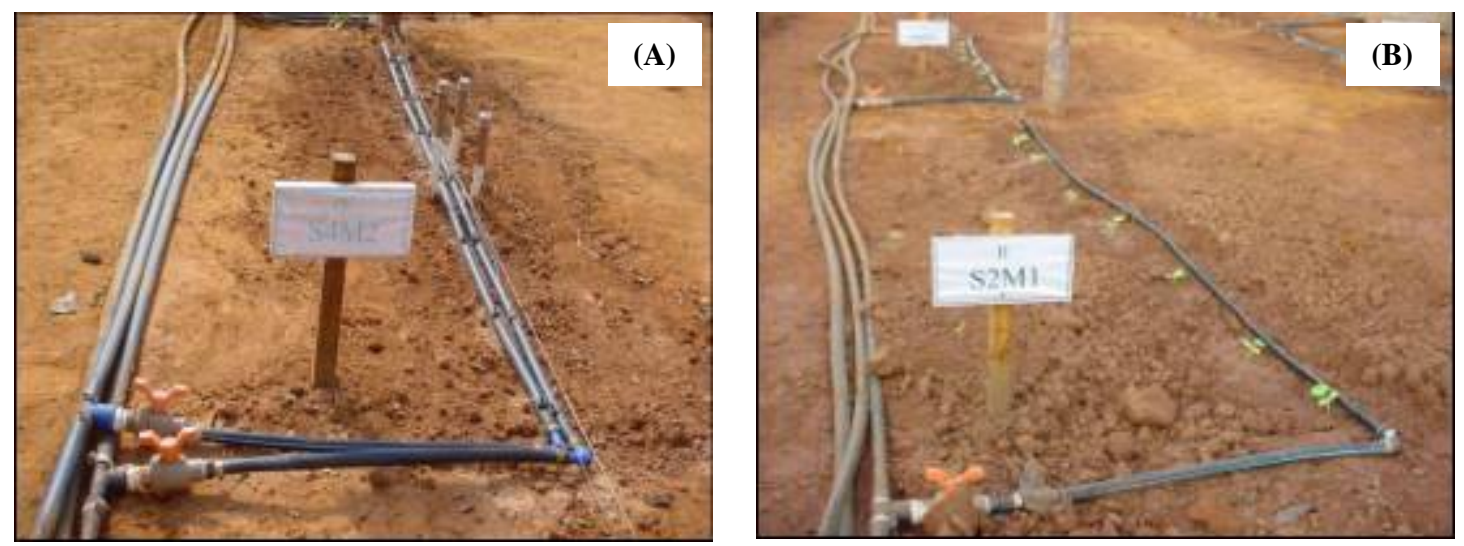

Figura 4 - Detalhes das parcelas experimentais mostrando o controle da fertirrigação: manejo controlado com duas linhas de gotejadores (A) e manejo tradicional com uma linha de gotejadores (B)

O manejo de irrigação foi feito com base em dados de umidade do solo, obtidos pela utilização de tensiômetros instalados a 0,20 e 0,40 m de profundidade e de uma curva característica de retenção de água no solo, construídas durante o experimento I. Foi estabelecido um turno de rega fixo de 2 dias e utilizado-se a tensão média no 
tensiômetro a $20 \mathrm{~cm}$ para se definir a quantidade de água a ser aplicada, suficiente para elevar o conteúdo de água do volume de solo úmido à capacidade de campo.

O volume de água aplicado foi calculado a partir da curva característica de retenção da água no solo e das médias das leituras tensiométricas para cada nível de salinidade. Paralelamente, caracterizou-se a demanda hídrica atmosférica no interior da estufa, para fins comparativos, a partir de estimativas da evapotranspiração, tomando como base leituras de temperatura e umidade relativa, obtidos com um termohigrômetro.

\section{Adubação}

A aplicação dos fertilizantes foi realizada via água de irrigação, sendo o manejo diferenciado para os tratamentos $\mathrm{M}_{1}$ e $\mathrm{M}_{2}$. Para o tratamento $\mathrm{M}_{1}$ foram utilizadas as recomendações propostas por Kano (2002), sendo observada a marcha de absorção da cultura. A freqüência da fertirrigação para este tratamento seguiu a mesma freqüência da irrigação.

Para o tratamento referente ao manejo $\mathrm{M}_{2}$, inicialmente, foi utilizada a mesma recomendação do manejo $\mathrm{M}_{1}$. Entretanto, a partir de 8 DAT, não foi pré-estabelecida a freqüência nem a proporção dos fertilizantes aplicados neste manejo. A fertirrigação só foi realizada quando a condutividade elétrica na solução do solo estava em média 20 \% abaixo dos níveis iniciais de salinização do solo para cada tratamento e esta foi cessada quando a condutividade atingia, em média, 20 \% acima dos mesmos níveis iniciais. Desta forma a concentração iônica total na solução do solo foi que controlou o manejo da fertirrigação. Quando não foi necessário aplicar fertilizantes o evento de irrigação era realizado só com água.

Utilizaram-se como fontes de fertilizantes os seguintes produtos: nitrato de amônio, cloreto de potássio, sulfato de magnésio, acido fosfórico e nitrato de cálcio. Para injetar os adubos no sistema de irrigação, a solução de fertilizante era preparada 20 minutos antes da irrigação em um tanque de $500 \mathrm{~L}$, sendo a concentração (mg L ${ }^{-1}$ ) suficiente para se aplicar as quantidades de adubos, em mg planta ${ }^{-1}$ dia $^{-1}$, durante 5 
minutos ou em tempo igual àquele correspondente ao tratamento de menor tempo de irrigação, sendo que no tempo de irrigação restante se aplicava apenas água.

\subsubsection{Características avaliadas}

\section{Rendimento e qualidade dos frutos}

Para as análises da qualidade dos frutos foram selecionados dois frutos representativos de cada parcela e, para a produção e os componentes de produção, foram utilizados todos os frutos da área útil da parcela. As características avaliadas relacionadas ao rendimento e qualidade dos frutos foram:

- Rendimento total de frutos por planta $\left(\mathrm{g}_{\text {planta }}{ }^{-1}\right)$ : obtido dividindo o peso total de frutos da parcela pelo número de plantas úteis (5 plantas).

- Rendimento comercial por planta (g planta ${ }^{-1}$ ): obtido dividindo o peso comercial de frutos da parcela pelo número de plantas úteis. O rendimento comercial foi obtido pela diferença entre rendimento total e a dos frutos não comercial. Os frutos não comerciais foram aqueles que apresentavam danos mecânicos, manchas, deformações e peso inferior a 0,550 kg (Filgueira et al., 2000).

- Peso médio de frutos comerciais e totais $\left(\mathrm{g}_{\text {fruto }}{ }^{-1}\right.$ ): obtido pelo somatório do peso total e comercial de cada parcela dividida pelo número de frutos da parcela.

- Sólidos solúveis totais ( ${ }^{\circ}$ Brix): determinados com refratômetro digital, com compensação de temperatura automática. As amostras foram obtidas pela retirada de uma fatia do fruto, cortado longitudinalmente, seguida da homogeneização da polpa em um liquidificador industrial e também por meio da retirada de algumas gotas diretamente da região equatorial do fruto, em uma fatia longitudinal.

- Firmeza da polpa do fruto (textura): o fruto foi dividido longitudinalmente em quatro partes, sendo que em cada uma delas se procedeu uma leitura da resistência exercida por um penetrômetro com pluger de ponta cônica de $8 \mathrm{~mm}$ de diâmetro (em regiões diferentes). Os resultados médios foram expressos em newton (N). 


\section{Elementos morfológicos}

Para a avaliação morfológica das plantas foram escolhidas aleatoriamente duas plantas de cada parcela, sendo avaliadas as seguintes variáveis:

- Altura das plantas: medindo-se do colo da planta até o ápice da folha mais alta, realizada semanalmente, até o final do ciclo.

- Diâmetro do colo: do início ao final do ciclo da cultura, foram realizadas medições a cada semana do diâmetro do colo das plantas, a $1 \mathrm{~cm}$ de altura em relação à superfície do solo, com o auxílio de um paquímetro digital.

- Área foliar: estimada multiplicando-se o comprimento e a largura de todas as folhas das planta, medidas com uma régua, sendo o produto corrigido por um fator, obtido por meio de regressão linear, em que se comparou a área foliar avaliada pela régua e por um medidor eletrônico modelo LI-3100 (Cardoso, 2002).

- Acúmulo de fitomassa: no final do ciclo produtivo foram coletadas a parte aérea (caule e folha) de duas plantas de cada parcela e postas para secagem em estufa de circulação forçada de ar, à temperatura de $60{ }^{\circ} \mathrm{C}\left( \pm 1^{\circ} \mathrm{C}\right)$ até peso constante, sendo o material pesado em balança de precisão de 0,01 g, obtendo-se a fitomassa seca da parte aérea.

\section{Parâmetros físico-químicos do solo}

\section{Monitoramento da salinidade e da concentração iônica da solução do solo}

A condutividade elétrica da solução do solo foi medida após o término de cada evento de irrigação, utilizando-se para extração, cápsulas porosas sob vácuo. A concentração dos níveis de $\mathrm{NO}_{3}^{-}$e $\mathrm{K}^{+}$na solução do solo foram determinadas quinzenalmente por utilização de testes rápidos.

Para obtenção do extrato, retirava-se o ar de dentro dos extratores, introduzindose uma agulha na borracha especial de vedação, acoplada a uma seringa de $60 \mathrm{~mL}$, ou por meio de uma bomba de vácuo, criando uma sucção interna de aproximadamente 80 kPa (Figura 5). A aplicação do vácuo aos extratores se deu 12 horas após a irrigação, momento em que era verificada a umidade do solo, por meio de tensiometria. As cápsulas dos extratores e dos tensiômetros foram instaladas no centro de cada parcela, 
localizadas opostamente uma da outra, a uma profundidade de 0,20 m da superfície do solo e a uma distância de $0,10 \mathrm{~m}$ da planta.

Os valores de condutividade elétrica e concentração de íons macronutrientes medidos na solução, retirada a partir dos extratores de cápsula porosa a diferentes umidades do solo, foram comparados com os valores obtidos pelo método padrão, ou seja, pela medição da condutividade elétrica e concentração de íons macronutrientes no extrato da pasta saturada, sendo corrigidos os valores de leitura de condutividade elétrica da solução em função da umidade de saturação a partir da equação (4):

$$
\mathrm{CE}_{\mathrm{es}}=\mathrm{Ce} \frac{\mathrm{Ua}}{\mathrm{Us}}
$$

em que:

$\mathrm{CE}_{\mathrm{es}}=$ condutividade elétrica ou concentração de íons no extrato de saturação estimada, $\mathrm{dS} \mathrm{m}{ }^{-1}$ ou $\mathrm{mmol}_{\mathrm{C}} \mathrm{L}^{-1}$;

$\mathrm{C}_{\mathrm{e}}=$ condutividade elétrica ou concentração de íons na solução do solo obtida com extrator de solução, dS m${ }^{-1}$ ou mmol $_{\mathrm{C}} \mathrm{L}^{-1}$;

$\mathrm{U}_{\mathrm{a}}=$ umidade atual do solo durante o tempo de coleta da solução, $\mathrm{g} \mathrm{g}^{-1}$;

$\mathrm{U}_{\mathrm{s}}=$ umidade do solo na pasta saturada, $\mathrm{g} \mathrm{g}^{-1}$.
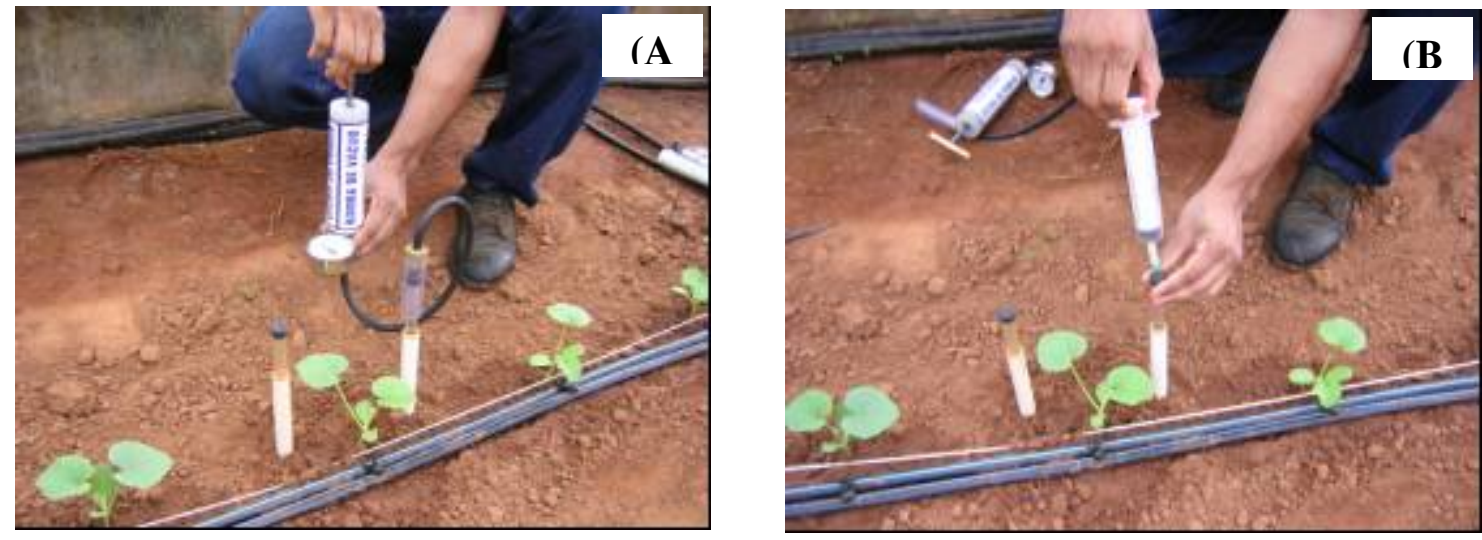

Figura 5 - Eliminação do ar no interior do extrator com bomba de sucção (A) e com seringas descartáveis (B) 


\section{Potencial mátrico do solo}

Avaliou-se o potencial mátrico médio durante o ciclo da cultura, monitorado diariamente por tensiômetros instalados a 0,20 e 0,40 m da superfície do solo, conforme a Figura 6.

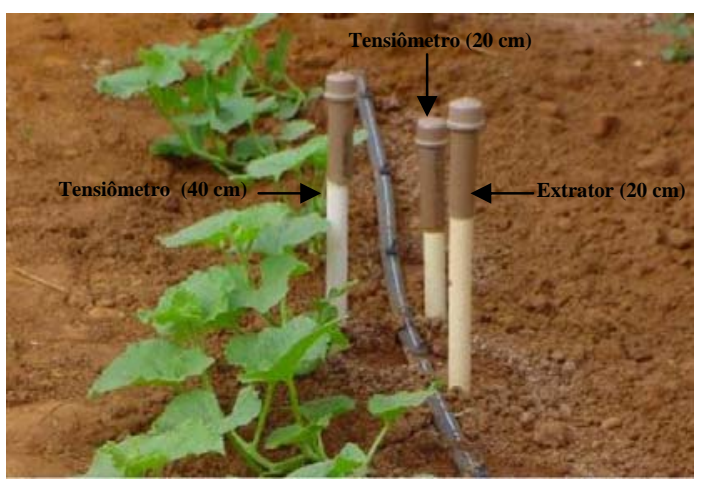

Figura 6 - Tensiômetros instalados a 0,20 e 0,40 m e extrator, localizado simetricamente ao tensiômetro instalado a $0,2 \mathrm{~m}$

\section{Evolução da salinidade a partir de amostras de solo}

Foram realizadas avaliações freqüentes da evolução da salinidade do solo ao longo do ciclo da cultura a partir de amostragem do solo. A determinação da salinidade do solo foi feita para as camadas 0-15, 15-30 e 30-45 cm, aos 30, 60 e 90 DAT. As amostras de solo, em cada parcela experimental, constituíram-se de amostras compostas de 3 pontos a 0,10 $\mathrm{m}$ do gotejador, em forma triangular. As amostras foram coletadas com um trado de solo tipo holandês, de $30 \mathrm{~mm}$ de diâmetro; estas foram secas ao ar, destorroadas e passadas em peneira de malha $2 \mathrm{~mm}$. Posteriormente, foram determinados as CE no extrato de saturação, conforme metodologia explicada no item 3.1.1. Realizou-se também análise química completa para as amostras compostas de cada tratamento.

Para se determinar o perfil transversal de salinidade do solo, ao longo do ciclo da cultura, foram retiradas amostras ao longo do ciclo do melão, à esquerda e à direita do gotejador, ou seja, coletadas a cada $0,15,30$, e $45 \mathrm{~cm}$ para ambos os lados nas camadas 
de 0-15, 15-30 e 30-45 cm (Figura 7), aos 45 e 90 DAT. A condutividade elétrica do extrato de saturação $\left(\mathrm{CE}_{\mathrm{es}}\right)$ destas amostras foi estimada com base em um estudo de regressão a partir da $\mathrm{CE}_{1: 2}$, medida no sobrenadante da mistura de uma parte de solo para duas de água destilada. A partir dos dados de $\mathrm{CE}_{\mathrm{es}}$ foram traçadas as curvas de evolução da salinidade ao longo do ciclo do meloeiro e os perfis de salinidade.

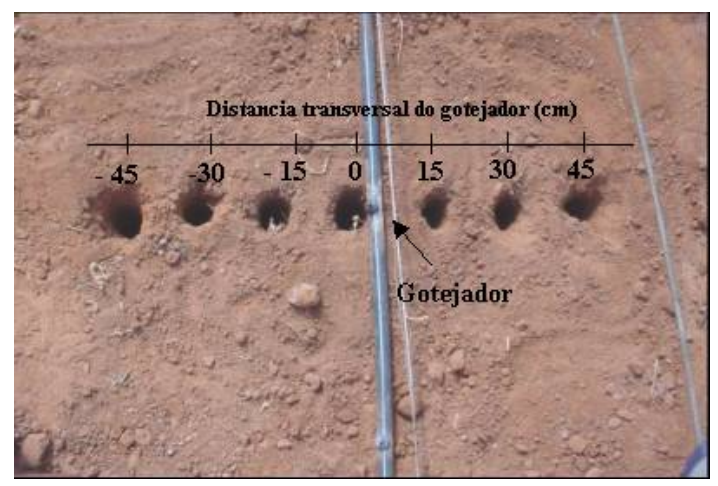

Figura 7 - Pontos de coleta das amostras de solo para determinar o perfil de distribuição de sais

\subsubsection{Análise estatística}

Os resultados de ambos os ciclos do meloeiro foram interpretados individualmente por meios da análise de variância. O fator quantitativo relativo aos níveis de salinidade iniciais do solo foi analisado estatisticamente por meio de regressão polinomial (linear e quadrática), enquanto que o fator manejo da fertirrigação foi analisado por teste de média, com base no teste de Tukey a 5 \% de probabilidade. 


\section{RESULTADOS E DISCUSSÃO}

\subsection{Experimento I - curvas de salinização artificial do solo}

A relação entre a concentração das soluções de fertilizantes utilizadas para salinizar o solo e a condutividade elétrica destas soluções pode ser observada na Figura 8A. Este gráfico de dispersão possibilita estimar as quantidades de fertilizantes a serem adicionadas com a finalidade de obter-se uma condutividade elétrica desejada na solução. A equação encontrada foi $\mathrm{CE}_{\mathrm{a}}=0,0009 \mathrm{C}+0,3096$ com valor de $\mathrm{R}^{2}$ igual a 0,9912, divergindo da equação proposta por Richards (1954) $\left(\mathrm{CE}_{\mathrm{a}}=0,00156 \mathrm{C}\right)$, devido possivelmente ao fato da condutividade elétrica ser afetada pela valência e concentração relativa dos íons contidos na solução (Rhoades, 1994). O fator 0,3096 da equação representa a CE inicial da água utilizada. Segundo Ferreira e Martinez (1997), a condutividade elétrica, além da temperatura, depende de outros fatores como: número de espécies iônicas presentes na solução, cargas das espécies iônicas, mobilidade de cada íons, área efetiva dos eletrodos e distância entre os eletrodos. Desta forma, a equação das curvas de salinização artificial depende dos tipos e das proporções de sais presentes na água de irrigação.

Quanto à salinização do solo, observa-se na Figura 8B que não há diferença sensível entre $\mathrm{CE}_{\mathrm{es}}$ esperada e a $\mathrm{CE}_{\mathrm{es}}$ obtida após a adição dos fertilizantes. Isto sugere que a metodologia adotada têm alta precisão para estimar as quantidades de sais fertilizantes aplicadas ao solo, necessária para se atingir uma $\mathrm{CE}_{\mathrm{es}}$ desejada. $\mathrm{O}$ modelo de curva de salinidade artificial é específico para cada tipo de solo e cultura, pois depende das características do solo e da recomendação da fertirrigação. 
De acordo com Richards (1954), o teor e o tipo de argila predominante no solo podem agir como interferentes na concentração de íons na solução e, conseqüentemente, no valor da $\mathrm{CE}_{\mathrm{es}}$. A fração argila age como um acumulador de íons por meio da sistemática de adsorção e posterior dessorção iônica, sendo influenciada principalmente pela temperatura e concentração iônica na solução do solo. Assim, quanto maior a concentração de um íon específico maior a adsorção deste no complexo coloidal. Entretanto, não foi verificado o efeito da adsorção dos sais fertilizantes para o solo estudado, possivelmente por tratar-se de um solo com alta porcentagem de areia (64 \%) de forma que a $\mathrm{CE}_{\mathrm{es}}$ esperada aproximou-se bastante da $\mathrm{CE}_{\mathrm{es}}$ obtida.

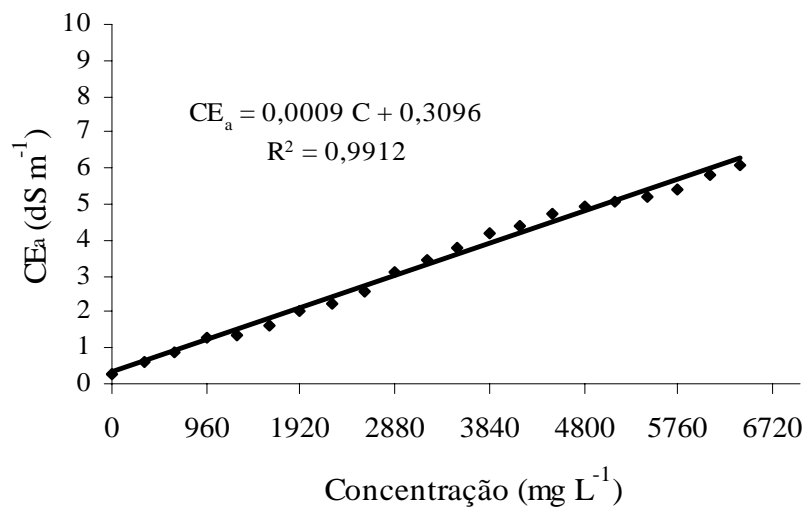

(A)

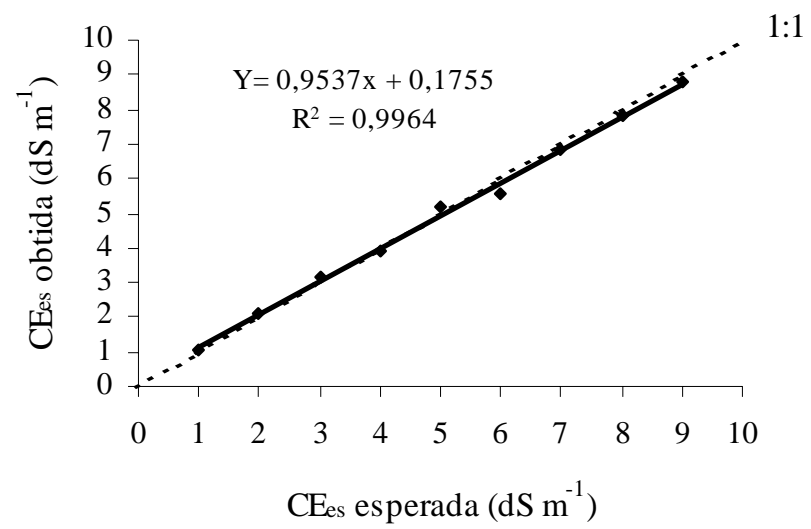

(B)

Figura 8 - Relações entre a concentração das soluções de fertilizantes e a condutividade elétrica das soluções utilizadas (A) e entre a $\mathrm{CE}_{\mathrm{es}}$ esperada e a $\mathrm{CE}_{\mathrm{es}}$ obtida após a adição dos fertilizantes (B).

A Figura 9 ilustra a curva de salinização artificial em função das concentrações dos fertilizantes aplicados via água para camada de 0-10 cm de solo no vaso. Pode-se observar boa correlação $\left(\mathrm{R}^{2}=0,9964\right)$ entre a concentração de sais na água e a $\mathrm{CE}_{\mathrm{es}}$ do solo estudado, o que permite estimar a quantidade de sais a serem aplicados ao solo com a finalidade de obter-se uma condutividade elétrica no extrato de saturação requerida.

Deve-se ressaltar que o volume de água aplicado ao solo durante o processo de salinização artificial correspondeu ao necessário para se elevar a umidade do solo à máxima capacidade de retenção, evitando que o excesso de água no solo promovesse a lixiviação dos sais. 


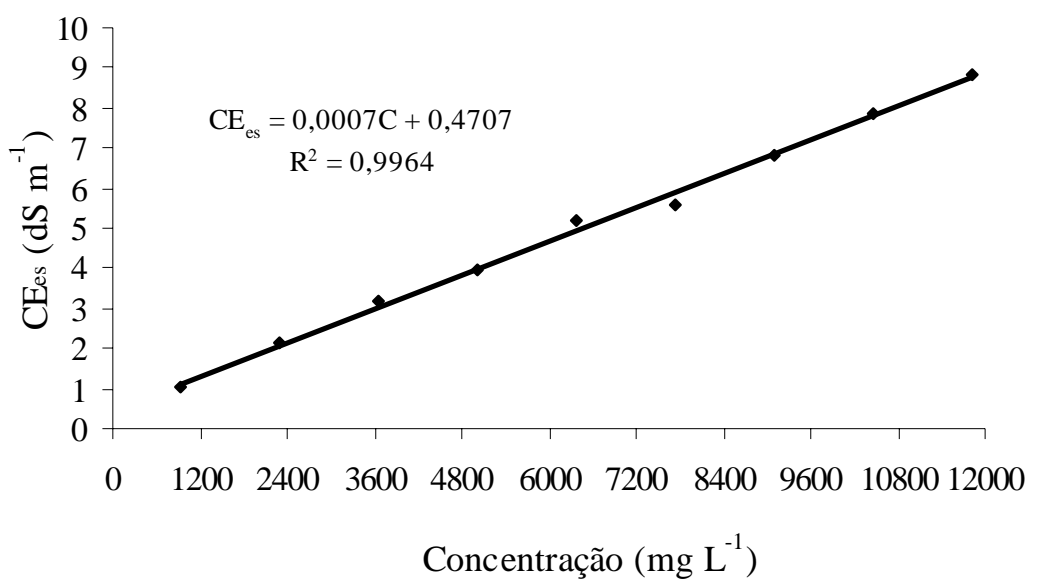

Figura 9 - Curva de salinização artificial (relação entre a concentração de fertilizantes aplicada via água de irrigação e a $\mathrm{CE}_{\mathrm{es}}$ )

\subsection{Experimento II}

\subsubsection{Salinização artificial do solo}

Procedeu-se a salinização artificial do solo em cada parcela experimental, das duas estufas, aplicando-se uma lâmina de água com fertilizantes, tendo como base os resultados obtidos no experimento I. Dois dias após a aplicação dos fertilizantes retirouse amostras de solo de cada parcela para verificação da $\mathrm{CE}_{\mathrm{es}}$, conforme metodologia proposta por Richards (1954), os quais são apresentados na Figura 10. Os valores de salinidade obtidos foram inferiores aos valores desejados, exceto para o menor nível $\left(\mathrm{S}_{1}\right.$

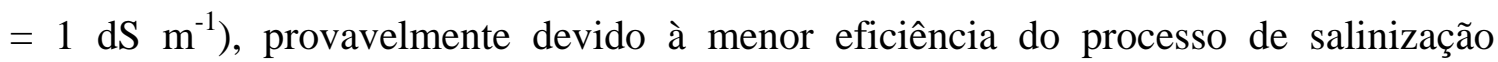
artificial nas parcelas do experimento II quando comparada com a dos vasos. Com base nos valores de $\mathrm{CE}_{\text {es }}$ obtidos, aplicou-se uma solução de correção no solo utilizado nas parcelas experimentais para se obter o nível de salinidade média desejada (Figura 10). Nota-se que a equação utilizada na correção da $\mathrm{CE}_{\text {es }}$ (equação 3) teve um desempenho relativamente bom. 
๑ Salinização ๑ Salinização + correção

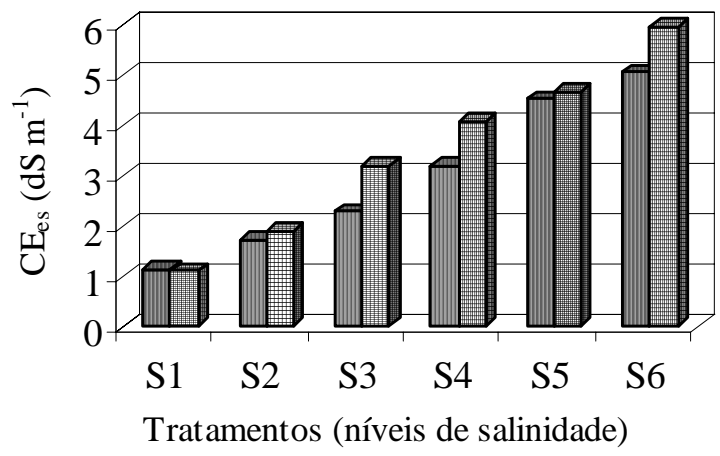

Figura 10 - Valores médios de CE medidos no extrato de saturação do solo, em dS m${ }^{-1}$, após a salinização artificial e após a correção para os diferentes tratamentos

\subsubsection{Caracterização climática}

\section{Temperatura e umidade relativa}

O meloeiro é uma planta exigente em temperatura e requer clima quente e seco. A faixa térmica ideal deve situar-se entre 25 e $35{ }^{\circ} \mathrm{C}$; temperaturas inferiores a $13{ }^{\circ} \mathrm{C}$ paralisam o crescimento vegetativo e reduzem a atividade dos polinizadores; já em condição de temperatura elevada, acima de $35^{\circ} \mathrm{C}$, há a queda de flores e frutos novos; quando acompanhada de ventos quentes causa rachaduras nos frutos e, ainda, provoca o aborto de flores (Nicolas et al., 1989; Brandão Filho \& Collegari, 1999; Filgueira, 2000).

A variação diária da temperatura (média, mínima e máxima) e da umidade relativa do ar, medidas durante os dois ciclos consecutivos do meloeiro, estão dispostas na Figura 11. Observa-se que a temperatura media diária no $1^{\circ}$ ciclo variou de 13,4 a $27,0^{\circ} \mathrm{C}$, faixa considerada inadequada para o desenvolvimento da cultura, enquanto para o $2^{\circ}$ ciclo esta variação foi de 19,97 a $29,01{ }^{\circ} \mathrm{C}$, faixa considerada suficiente para o desenvolvimento das plantas. 
(A)

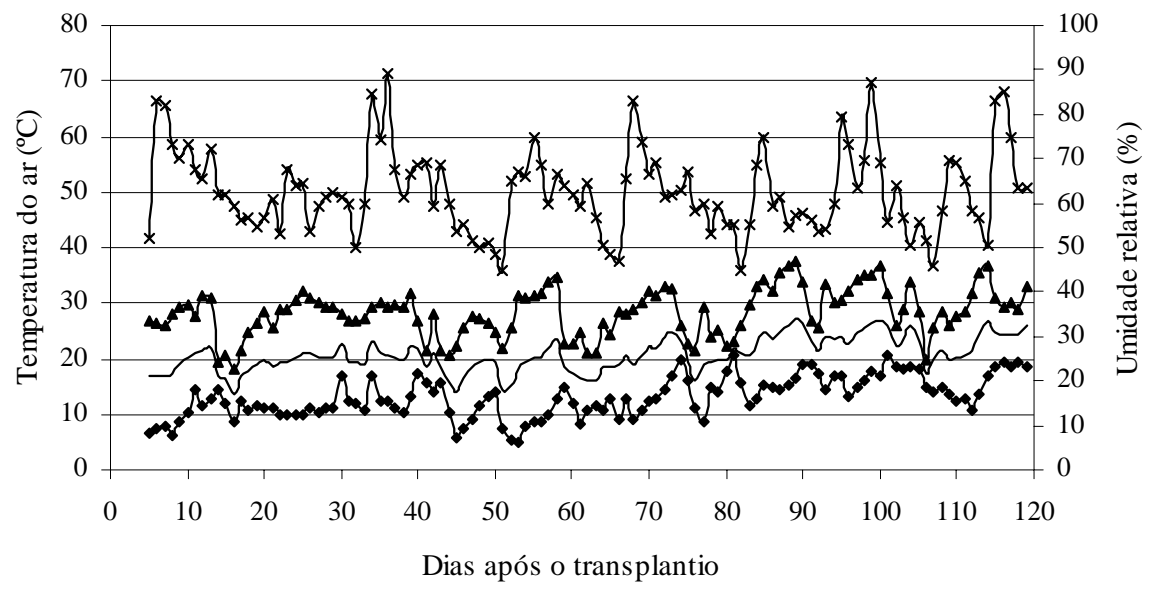

(B)

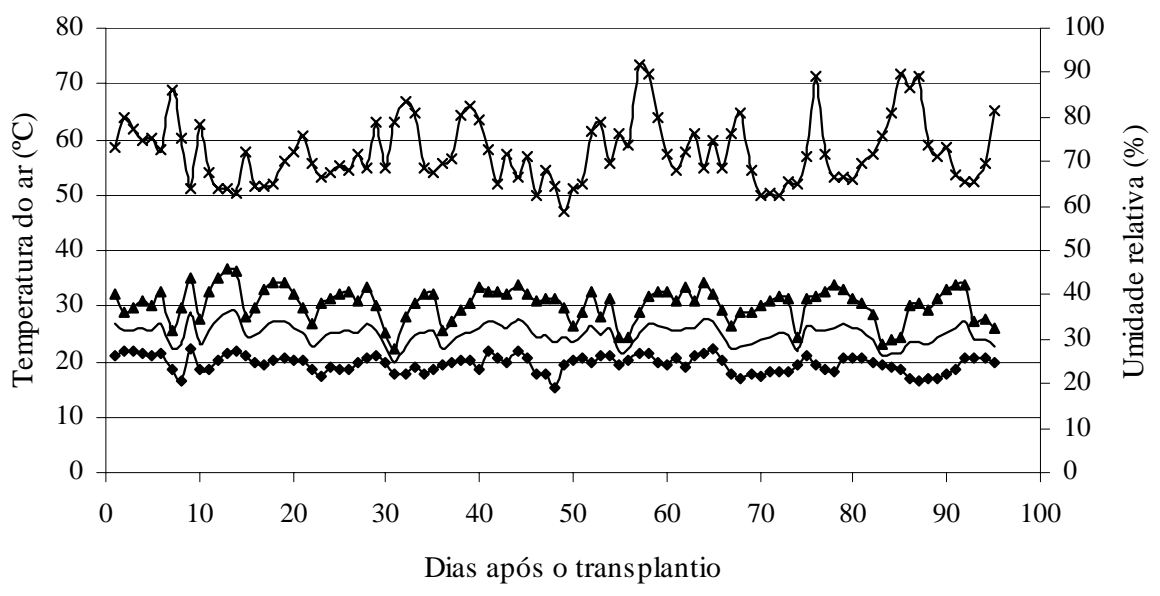

— Média $\multimap-$ Mínima $\multimap$ Máxima $\multimap$ UR

Figura 11 - Variação das temperaturas do ar (máxima, mínima e média) e umidade relativa média no interior do ambiente protegido ao longo do primeiro (A) e do segundo (B) ciclo da cultura do meloeiro

Ainda em relação aos dados apresentados na Figura 11, os valores de umidade relativa (UR) oscilaram entre 44,7 e 89,2 \% com média diária de 62,6 \% e entre 57,0 e 89,2 \% com média diária de 70,1 \%, durante o $1^{\circ}$ e $2^{\circ}$ ciclo, respectivamente. De acordo com Zapata et al. (1989) as faixas de UR mais favoráveis à cultura do melão são de 55 a 75 \%, no desenvolvimento inicial, de 60 a 70 \% na floração e 55 a 65 \% na frutificação. 
De modo geral, pode-se inferir que durante os dois ciclos da cultura a UR apresentou média diária adequada, o que provavelmente não interferiu negativamente no desenvolvimento das plantas.

O meloeiro requer calor e umidade não excessiva para a produção, do contrário seu desenvolvimento é comprometido, os frutos não amadurecem bem e perdem qualidade, principalmente em regiões úmidas e com pouca insolação (Cardoso, 2002).

\section{Radiação solar}

As variações da radiação solar global (Rsg) e líquida (Rsl), medidas no interior do ambiente protegido ao longo dos dois ciclos consecutivos do meloeiro são apresentadas na Figura 12.

Nota-se que durante o primeiro ciclo, os valores integrados das energias para radiação solar global totalizou 1.616,79 $\mathrm{MJ} \mathrm{m}^{-2}$ com média de $14,06 \mathrm{MJ} \mathrm{m}^{-2} \mathrm{dia}^{-1}$ e a radiação líquida totalizou $841,98 \mathrm{MJ} \mathrm{m}^{-2}$ com média de 7,32 $\mathrm{MJ} \mathrm{m}^{-2}$ dia $^{-1}$. No que concerne ao segundo ciclo, constata-se que os valores integrados das energias para radiação solar global e líquida totalizaram 1.726,13 $\mathrm{MJ} \mathrm{m}^{-2}$ com média de 15,01 $\mathrm{MJ} \mathrm{m}^{-2}$ dia ${ }^{-1}$ e 924,12 $\mathrm{MJ} \mathrm{m}^{-2}$ com média de 9,73 $\mathrm{MJ} \mathrm{m}^{-2}$ dia $^{-1}$, respectivamente.

Segundo Andriolo (1999), no caso das hortaliças de verão como o melão, considerase o nível de radiação líquida adequado aproximadamente igual a $8,4 \mathrm{MJ} \mathrm{m}^{-2}$ dia $^{-1}$ como limite trófico (produção mínima de assimilados necessária para a manutenção da cultura). A radiação líquida média registrada durante o primeiro ciclo do presente trabalho foi inferior ao limite citado e, somente aos 70 DAT começaram a ser verificados valores de radiação líquida capazes de atender a demanda mínima do meloeiro.

Os valores de Rsg tendem ao mínimo em condições de baixa energia (dias nublados). Cardoso (2002), no período de 4 de setembro a 15 de dezembro de 2001, cultivando em estufas o mesmo híbrido de melão em Piracicaba, encontrou Rsg média de 29,39 $\mathrm{MJ} \mathrm{m}^{-2} \mathrm{dia}^{-1}, 52,1$ e 48,9 \% a mais do que o registrado, respectivamente, no $1^{\circ} \mathrm{e}$ $2^{\circ}$ ciclo no presente trabalho, devido possivelmente às características de dimensões do ambiente protegido e à época de cultivo. 
(A)

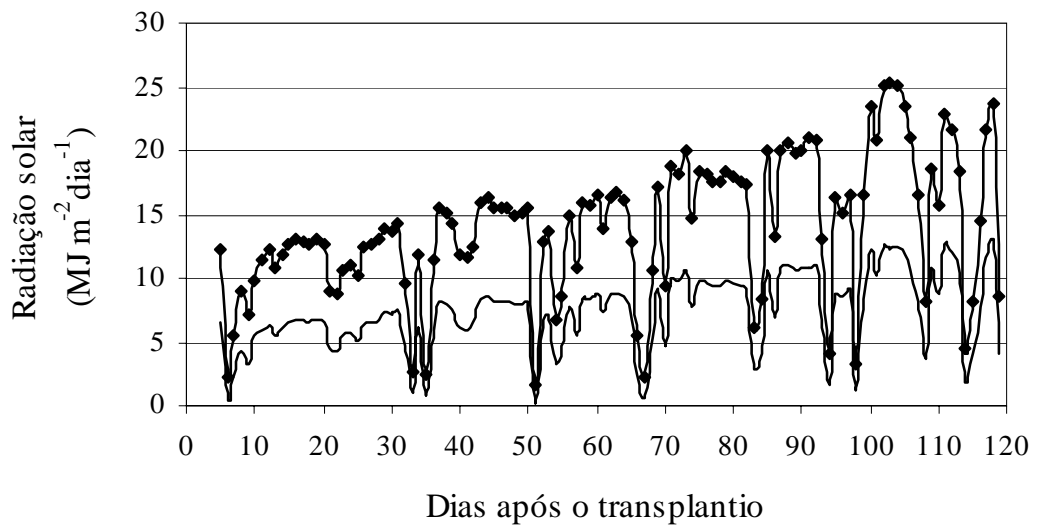

(B)

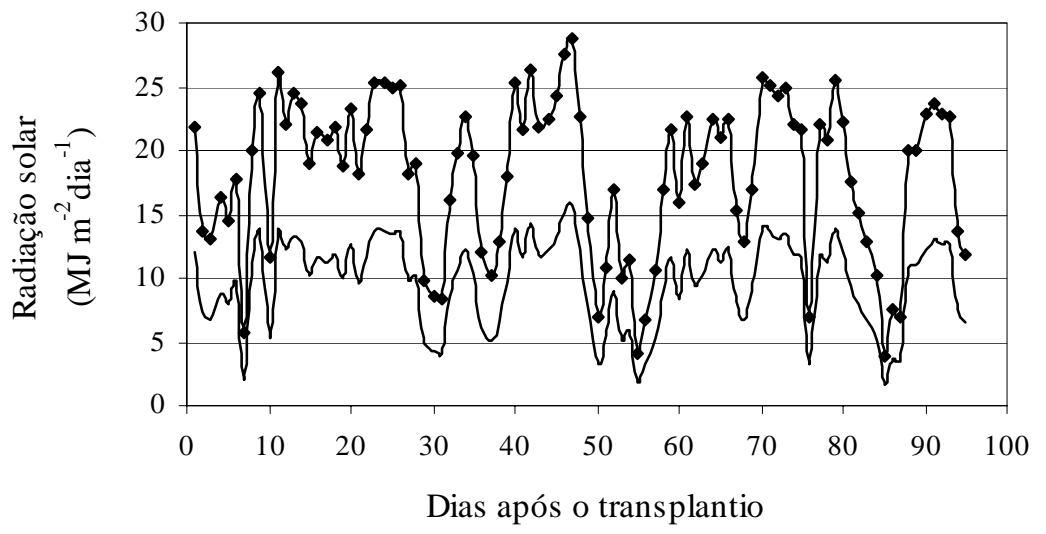

$\longrightarrow$ Rsg — Rsl

Figura 12 - Radiação solar global (Rsg) e líquida (Rsl) ao longo do primeiro (A) e do segundo ciclo (B) da cultura do meloeiro em condições protegidas

\subsubsection{Monitoramento da salinidade do solo}

Observa-se, na Figura 13, um ajuste razoável $\left(R^{2}=0,62\right)$ entre os valores de condutividade elétrica medidos no extrato de saturação e estimados a partir da condutividade elétrica da solução $\left(\mathrm{CE}_{\mathrm{s}}\right)$ obtida com extratores de cápsula porosa, com correção em função da umidade. Pode-se notar que o valor de $\mathrm{CE}_{\text {es }}$ estimado pelas 
leituras de $\mathrm{CE}_{\mathrm{s}}$, com umidade corrigida, superou a condutividade elétrica do extrato de saturação medida em média 5,55 \% ( $<<0,01)$.

A utilização do método de medição da condutividade elétrica da solução obtida com extrator de cápsula porosa é bastante eficiente, devido a sua facilidade, versatilidade e praticidade, quando se compara com o da solução diluída 1:2, desde que sejam conhecidas a umidade da pasta saturada e a umidade no momento da extração. Silva et al. (1999) verificaram que a CE obtida por extratores corrigidas para umidade de saturação se equivale relativamente bem à CE do extrato de saturação medida pelo método padrão (Richards, 1954).

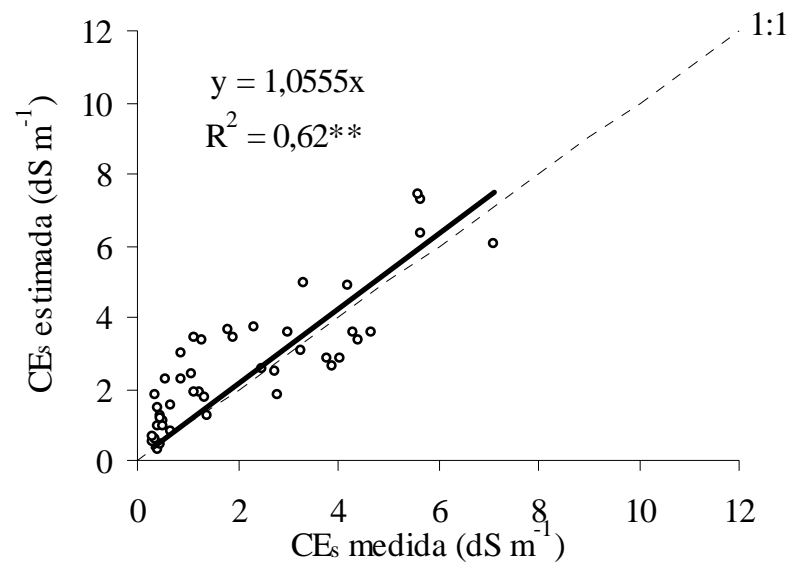

Figura 13 - Relação entre os valores de $\mathrm{CE}_{\mathrm{es}}$ medida e estimada a partir da $\mathrm{CE}_{\mathrm{s}}$ obtida com extratores de cápsula porosa, com correção em função da umidade

Na Figura 14 estão apresentados os valores de condutividade elétrica do extrato de saturação do solo, estimadas por meio da correção dos valores de CE da solução extraída nas cápsulas porosas instaladas a $20 \mathrm{~cm}$ de profundidade, para os dois manejos da fertirrigação, ao longo dos dois ciclos consecutivos do meloeiro.

No primeiro ciclo, verifica-se que no manejo da fertirrigação tradicional ocorre um aumento da salinidade do solo para os tratamentos de níveis mais baixos $\left(\mathrm{S}_{1}, \mathrm{~S}_{2}\right.$ e $\left.\mathrm{S}_{3}\right)$ e um decréscimo da salinidade para os níveis mais elevados $\left(S_{4}, S_{5}\right.$ e $\left.S_{6}\right)$, com uma tendência de equilíbrio no final do primeiro ciclo e durante o segundo ciclo. Esta tendência de equilíbrio dos sais se dá em razão do fato de que apenas parte dos sais fertilizantes incorporados via água de irrigação ficam no solo, pois uma parte é 
absorvida pelas plantas para atender às suas necessidades, ou ainda, torna-se insolúvel mediante a precipitação, quer por reações químicas ou por atingir limites de solubilidade na solução do solo. Além disso, outra parte, embora em quantidade pequena, pode ser eliminada por percolação, por meio da aplicação não intencional de eventuais lâminas de irrigação excessivas.

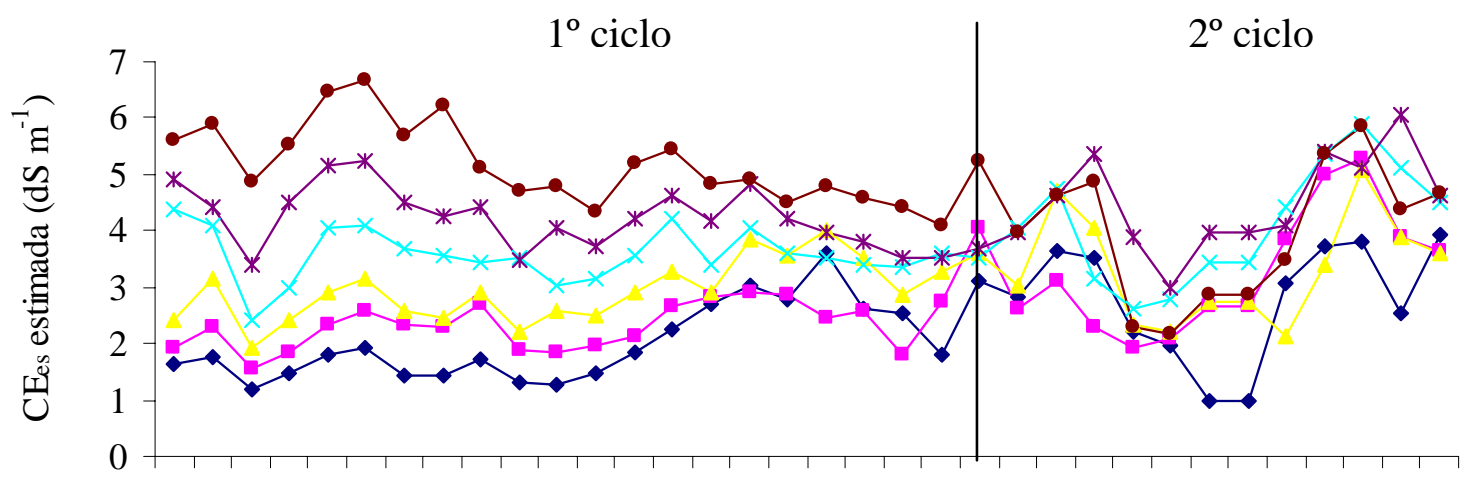

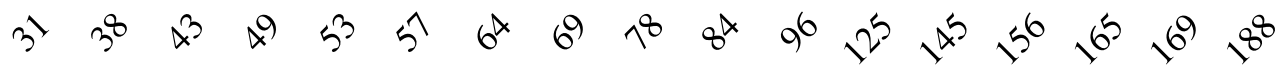

(A)

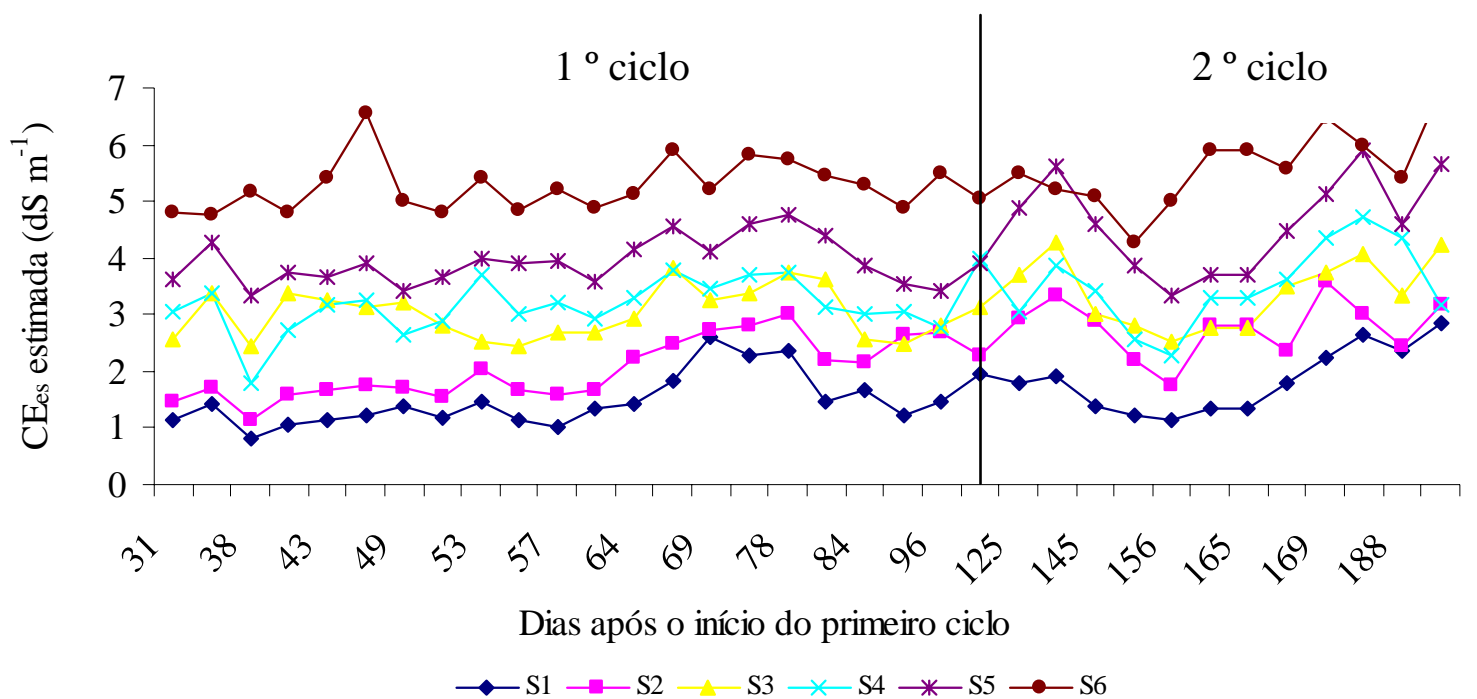

(B)

Figura 14 - Valores de condutividade elétrica do extrato de saturação do solo, estimados a partir dos valores medidos na solução obtida por extratores, ao longo dos dois ciclos do meloeiro, para os dois manejos da fertirrigação propostos: manejo tradicional- $\mathrm{M}_{1}$ (A) e manejo controlado- $\mathrm{M}_{2}$ (B) 
Por outro lado, no manejo controlado, verifica-se uma orientação com menor número de cruzamentos de curvas dos níveis de salinidade, que se mantêm aproximadamente constantes ao longo dos dois ciclos. A manutenção dos níveis iniciais de salinidade ao longo dos dois ciclos do meloeiro ocorreu devido ao bem sucedido monitoramento e correção da condutividade elétrica da solução do solo.

De acordo com Padilla (1998), se os problemas de salinidade criados pelo manejo inadequado dos fertilizantes forem a causa da redução do rendimento da cultura, deve-se corrigi-los antes de se empregar algum outro esforço físico ou econômico; neste caso, a evolução da salinidade do solo pode ser impedida com base no monitoramento da condutividade elétrica e com a correção das quantidades aplicadas de fertilizantes. Assim, fica evidenciado que o monitoramento da condutividade elétrica da solução do solo extraída por cápsulas porosas permite evitar possíveis processos de salinização e ou deficiência nutricional (Silva, 2002).

Deve-se ressaltar que ao se utilizar extratores para se obter a solução do solo, é importante corrigir-se os valores da condutividade elétrica em função da umidade do solo no momento de coleta, tomando como base as leituras dos tensiômetros, que permitem conhecer com que grau de tensão a água está retida no solo.

\subsubsection{Estimativa da $\mathrm{CE}_{\mathrm{es}}$ a partir da $\mathrm{CE}_{1: 2}$}

A estimativa da $\mathrm{CE}$ em diferentes relações solo : água destilada $\left(\mathrm{CE}_{1: 2}\right)$ tem a vantagem de ser rápida, ter custos relativamente baratos e não precisar de equipamentos para retirar o extrato do solo; porém, apresenta o inconveniente de necessitar do préestabelecimento da relação entre a $\mathrm{CE}_{\mathrm{es}}$ e a CE da solução aquosa do solo estudado. De acordo com Rhoades \& Miyamoto (1990) a troca catiônica, a composição e a concentração total dos sais, a hidrólise, a dissolução mineral e as características de retenção de umidade do solo podem afetar essas relações, o que representa um problema na utilização dos extratos diluídos. 
A Figura 15 A mostra a relação entre a $\mathrm{CE}_{\mathrm{es}}$ e $\mathrm{CE}_{1: 2}$, seu coeficiente de determinação e sua equação, encontradas para as amostras do solo estudado. A equação que relaciona a $\mathrm{CE}_{\mathrm{es}}$ estimada por meio de soluções mais diluídas encontrada foi $\mathrm{CE}_{\mathrm{es}}=$ 4,4519CE $E_{1: 2}+0,0242\left(\mathrm{R}^{2}=0,9129\right)$, podendo a $\mathrm{CE}_{1: 2}$ ser utilizada com boa precisão para estimar a $\mathrm{CE}_{\mathrm{es}}$, pois existe alta correlação. Segundo Medeiros et al. (1996) é comum encontrar coeficiente de determinação acima de 0,90 para a relação entre $\mathrm{CE}_{1: 2}$ e $\mathrm{CE}_{\mathrm{es}}$. Filgueira \& Souto (1995) também verificaram a possibilidade de se utilizar extratos obtidos em relações 1:1 e 1:5, em substituição ao extrato de saturação, em solos salinosódicos e sódicos degradados da região de Patos, estado da Paraíba.

A Figura 15 B mostra a relação entre a condutividade elétrica do extrato de saturação medida e a estimada a partir $\mathrm{CE}_{1: 2}$ com correção em função dos diferentes valores de umidade obtidos em cada método. Verifica-se que a $\mathrm{CE}_{\mathrm{es}}$ estimada a partir da solução diluída ( $\left.\mathrm{CE}_{1: 2}\right)$, com umidade corrigida, superou a condutividade elétrica do extrato de saturação medida, principalmente para os valores mais elevados de CE.

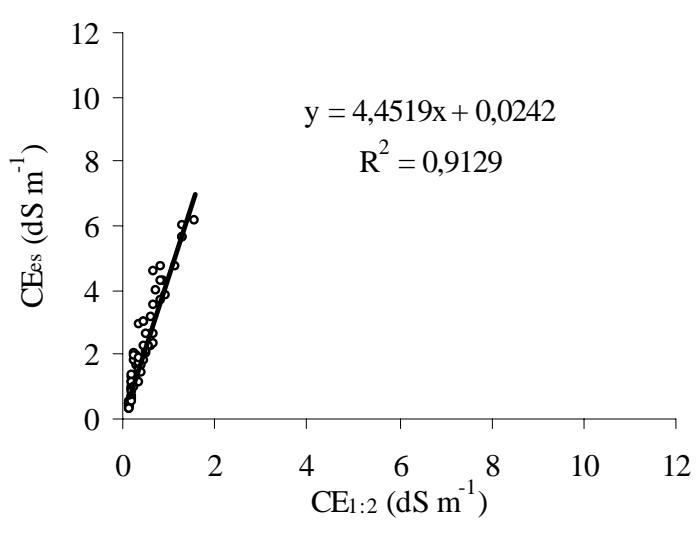

(A)

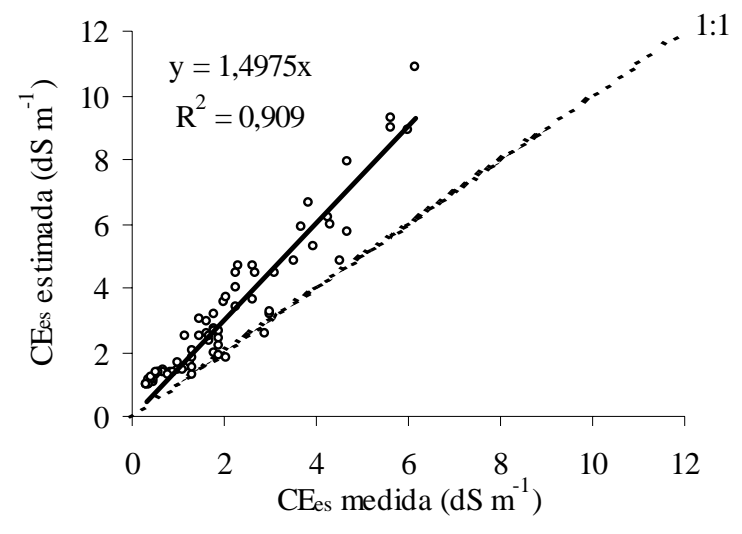

(B)

Figura 15 - Relação entre a $\mathrm{CE}_{\mathrm{es}}$ e $\mathrm{CE}_{1: 2}(\mathrm{~A})$ e a relação entre os valores $\mathrm{CE}_{\mathrm{es}}$, medidos e estimados a partir $\mathrm{CE}_{1: 2}$, com correção em função da umidade de cada método (B), para o solo estudado 
Conforme Hoorn \& Alphen (1994) o coeficiente linear da reta apresentado na Figura 15 B sensivelmente maior que $1(\mathrm{a}=1,4975)$ representa o incremento de CE da suspensão devido à solubilidade de sais precipitados ao adicionar maior volume de água nas soluções diluídas, o que constitui uma desvantagem do método. De acordo com Richards (1954), a segurança nas determinações de soluções mais diluídas depende das características do solo e dos tipos de sais presentes pois, sais de baixa solubilidade precipitados no solo podem ser dissolvidos em proporções maiores que no extrato de saturação, devido à adição de água destilada e resultar em superestimativa dos riscos de salinidade.

\subsubsection{Análise química e correção da salinidade do solo}

As quantidades de nutrientes aplicadas (N, K, P, Ca e Mg) durante o primeiro ciclo do meloeiro são apresentadas na Figura 16 e no Apêndice 3. As quantidades de nutrientes mais elevadas nos níveis mais altos de salinidade do manejo controlado da fertirrigação $\left(\mathrm{M}_{2}\right)$ nas diferentes épocas de aplicação, em relação ao manejo tradicional $\left(\mathrm{M}_{1}\right)$, indica que foi necessário se aplicar adubos em maior dosagem para se corrigir a $\mathrm{CE}_{\mathrm{es}}$ e manter o nível de salinidade desejada ao longo do ciclo. De modo contrário, ou seja, a menor quantidade de nutrientes aplicados nos níveis mais baixos de salinidade do $\mathrm{M}_{2}$ em relação a $\mathrm{M}_{1}$ indica que a fertirrigação foi cessada para reduzir a $\mathrm{CE}_{\mathrm{es}}$, no manejo controlado, pois a $\mathrm{CE}_{\mathrm{es}}$ já ultrapassava, em média, 20 \% dos níveis iniciais.

Analisando-se a quantidade de nutrientes aplicados via água de irrigação nos diferentes níveis de salinidade, pode-se verificar a necessidade constante de correção da CE nos tratamentos com maiores nível de salinidade $\left(\mathrm{S}_{4}, \mathrm{~S}_{5}\right.$ e $\left.\mathrm{S}_{6}\right)$ do manejo controlado, principalmente na época 45-59 DAT, resultando em aplicação excessiva dos nutrientes no final do ciclo. Já nos tratamentos com menores níveis de salinidade $\left(S_{1}, S_{2}\right.$ e $\left.S_{3}\right)$ do manejo controlado, observa-se menores quantidades de nutrientes aplicados devido a necessidade de se cessar a fertirrigação para corrigir os níveis de salinidade, principalmente no nível de salinidade $S_{1}$, no qual a correção foi iniciada a partir de 30 DAT. Entretanto, conforme já discutido, houve uma tendência de aumento da salinidade 
nos níveis menores de salinidade de $\mathrm{M}_{1}$ e decréscimo para os níveis mais salinos deste manejo com o tempo, atingindo um equilíbrio (fato ilustrado na Figura 14A).

Deve-se ressaltar que na fertirrigação de correção não se levou em consideração a quantidade de íons específicos na solução do solo, sendo que a concentração iônica total na solução do solo foi que controlou o manejo da fertirrigação.

Para o manejo tradicional, as quantidades totais utilizadas até o final do ciclo foram: nitrogênio $=6,306 \mathrm{~g}_{\text {planta }}{ }^{-1}$, fósforo $=1,617 \mathrm{~g}$ planta $^{-1}$, potássio $=5,942 \mathrm{~g}$ planta $^{-1}$, cálcio $=4,528$ g planta $^{-1}$ e magnésio $=1,962$ g planta $^{-1}$, nas formas de nitrato de amônio, acido fosfórico, cloreto de potássio, nitrato de cálcio e sulfato de magnésio.

Sousa \& Sousa (1999), testando doses de nitrogênio e potássio por fertirrigação na produtividade do meloeiro, concluíram que doses de N e K superiores a 8,5 e 9,5 g planta $^{-1}$, respectivamente, proporcionaram queda na produtividade de frutos comerciais. Com base nesta afirmação, pode-se verificar que as dosagens de $\mathrm{N}$ e K aplicados nos tratamento $S_{4}, S_{5}$ e $S_{6}$, durante o primeiro ciclo (Apêndice 3), foram superiores aos limites estabelecido na literatura, o que pode acarretar em perdas na produtividade pelo efeito osmótico e, ainda, pelo desequilíbrio nutricional.

No que se refere ao segundo ciclo, constata-se que praticamente não houve correção da salinidade por meio da aplicação de adubos. De modo geral, o controle da salinidade se resumiu à aplicação de água nos tratamentos de níveis salinos menores $\left(\mathrm{S}_{1}\right.$, $\mathrm{S}_{2}$ e $\mathrm{S}_{3}$ ) e, eventualmente, correções com adubos ns níveis de salinidade $\mathrm{S}_{4}, \mathrm{~S}_{5}$ e $\mathrm{S}_{6}$. (Figura 17 e Apêndice 4). 


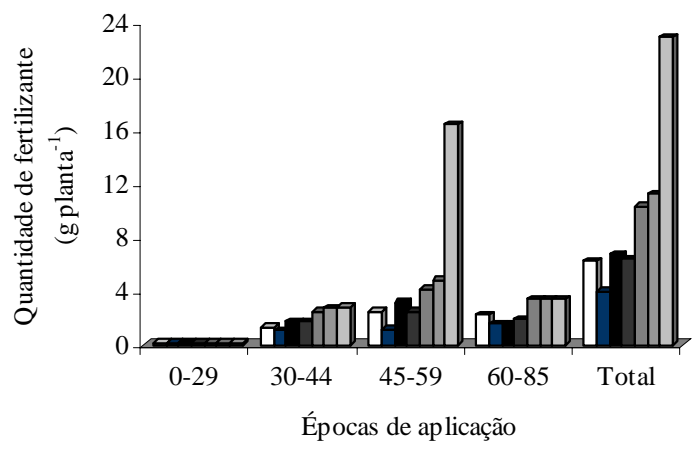

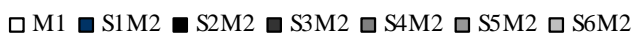

$(\mathrm{N})$

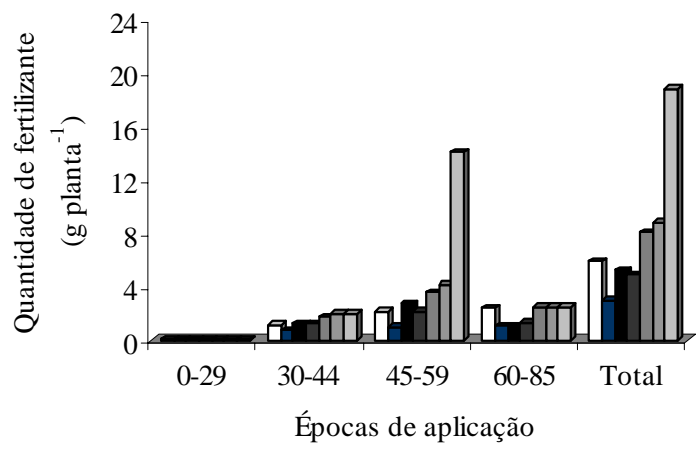

$\square \mathrm{M} 1 \square \mathrm{S} 1 \mathrm{M} 2 \square \mathrm{S} 2 \mathrm{M} 2 \square \mathrm{S} 3 \mathrm{M} 2 \square \mathrm{S} 4 \mathrm{M} 2 \square \mathrm{S} 5 \mathrm{M} 2 \square \mathrm{S} 6 \mathrm{M} 2$

$(\mathrm{K})$

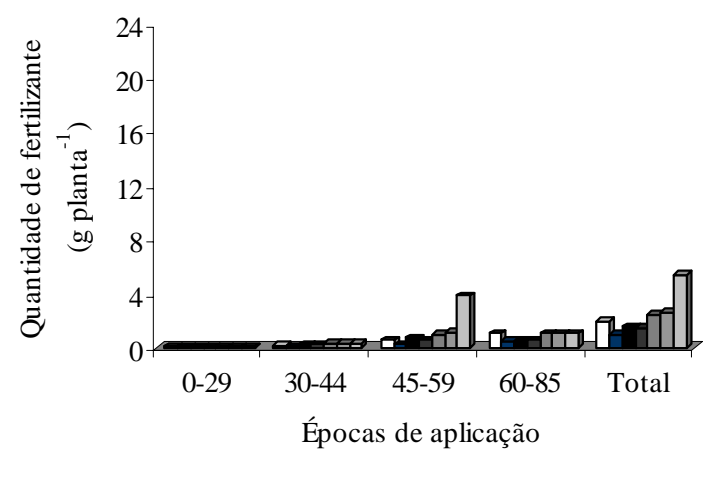

$\square \mathrm{M} 1 \square \mathrm{S} 1 \mathrm{M} 2 \square \mathrm{S} 2 \mathrm{M} 2 \square \mathrm{S} 3 \mathrm{M} 2 \square \mathrm{S} 4 \mathrm{M} 2 \square \mathrm{S} 5 \mathrm{M} 2 \square \mathrm{S} 6 \mathrm{M} 2$

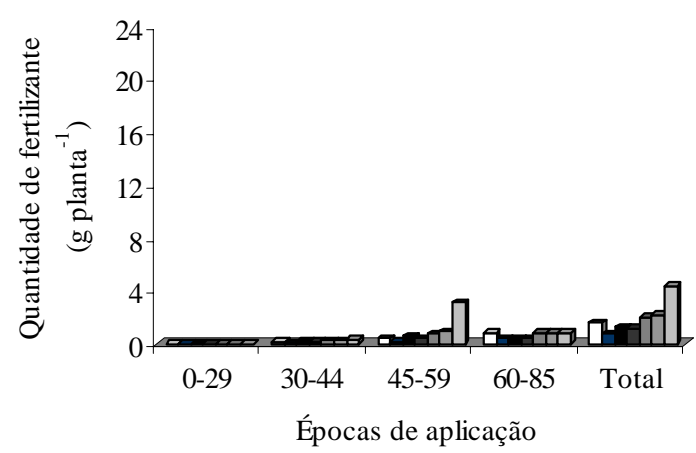

$\square \mathrm{M} 1 \square \mathrm{S} 1 \mathrm{M} 2 \square \mathrm{S} 2 \mathrm{M} 2 \square \mathrm{S} 3 \mathrm{M} 2 \square \mathrm{S} 4 \mathrm{M} 2 \square \mathrm{S} 5 \mathrm{M} 2 \square \mathrm{S} 6 \mathrm{M} 2$

(P)

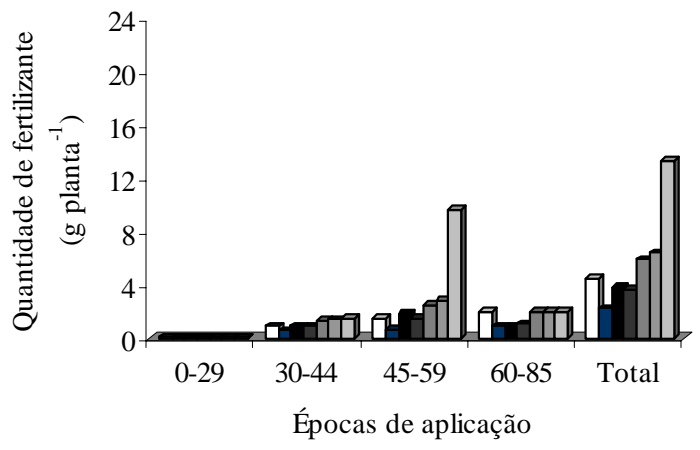

$\square \mathrm{M} 1 \square \mathrm{S} 1 \mathrm{M} 2 \square \mathrm{S} 2 \mathrm{M} 2 \square \mathrm{S} 3 \mathrm{M} 2 \square \mathrm{S} 4 \mathrm{M} 2 \square \mathrm{S} 5 \mathrm{M} 2 \mathrm{~S} 6 \mathrm{M} 2$

(Ca)

(Mg)

Figura 16 - Quantidade de nitrogênio $(\mathrm{N})$, fósforo $(\mathrm{P})$, potássio $(\mathrm{K})$, cálcio $(\mathrm{Ca})$ e magnésio (Mg) aplicados nas irrigações nas diferentes fases de desenvolvimento para o manejo tradicional e para os diferentes níveis de salinidade do manejo controlado da fertirrigação ao longo do primeiro ciclo 


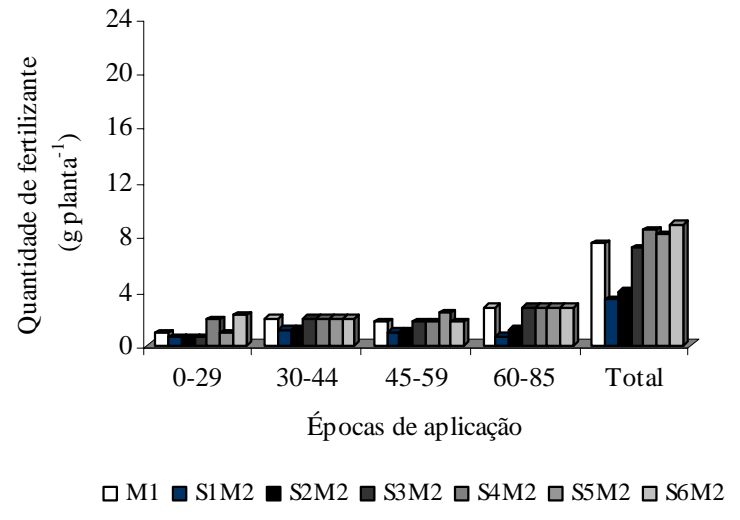

$(\mathrm{N})$

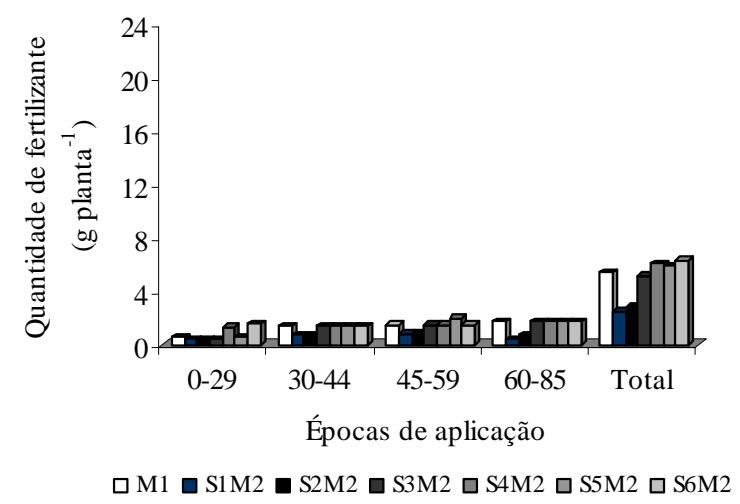

$(\mathrm{K})$

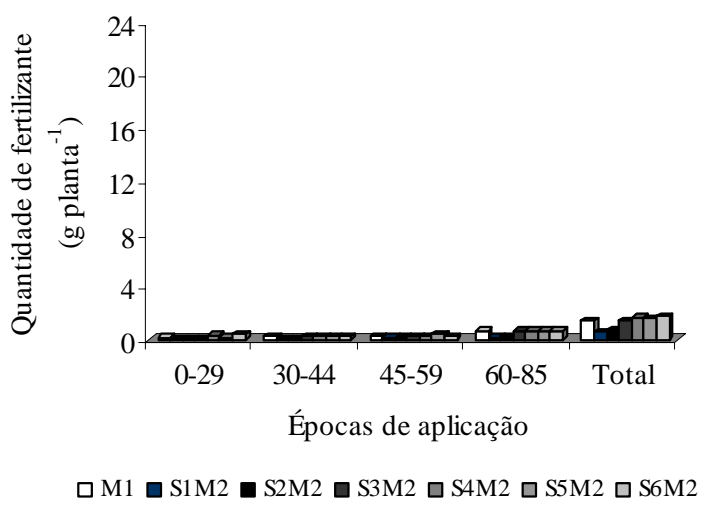

(P)

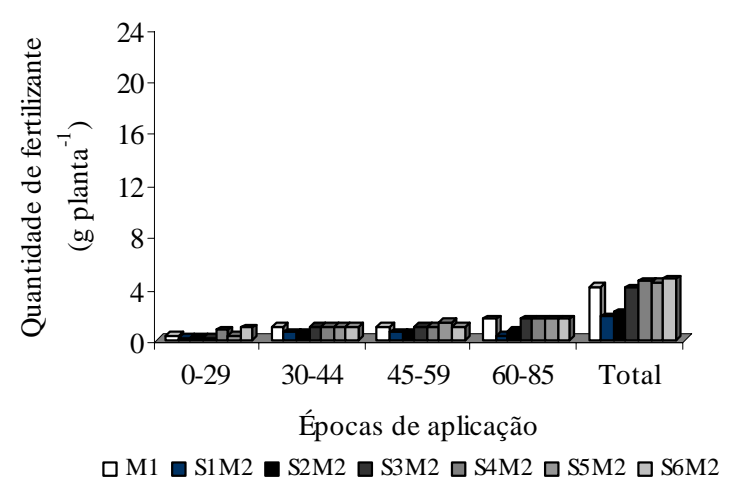

(Ca)

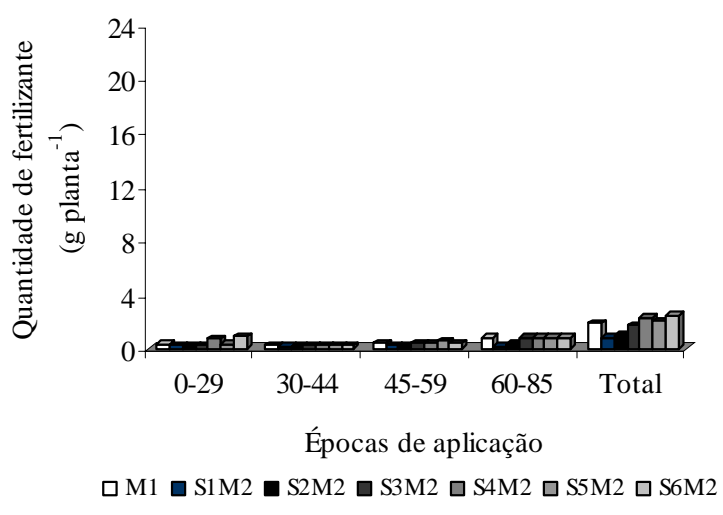

$(\mathrm{Mg})$

Figura 17 - Quantidade de nitrogênio $(\mathrm{N})$, fósforo $(\mathrm{P})$, potássio $(\mathrm{K})$, cálcio $(\mathrm{Ca})$ e magnésio (Mg) aplicados nas irrigações nas diferentes fases de desenvolvimento para o manejo tradicional e para os diferentes níveis de salinidade do manejo controlado da fertirrigação ao longo do segundo ciclo 
De acordo com os resultados da análise do solo realizada após a salinização artificial (Apêndice 5), observa-se que a soma total de base (SB) aumentou à medida que aumentaram os níveis desejados de salinidade. Entretanto, os valores de $\mathrm{CE}_{\mathrm{es}}$ obtidos foram diretamente proporcionais à soma total de cátions.

Conforme os resultados das análises do solo realizadas aos 60 e aos 90 DAT do primeiro ciclo (Apêndice 6 e 7), verifica-se que em todos os níveis de salinidade, os valores da SB para o manejo controlado foram sempre maiores do que os valores relativos ao manejo tradicional, exceto para os níveis $S_{1}$ e $S_{6}$, e $S_{1}$ e $S_{2}$, aos 60 e 90 DAT, respectivamente. Os menores valores de $S B$ nos níveis de salinidade $S_{1}$ e $S_{2}$ do manejo controlado estão relacionados com as menores quantidades de nutrientes aplicados devido à necessidade de diminuir estes níveis de salinidade, conforme relatado anteriormente. Já os valores de SB nas análises de solos realizadas aos 10, 45 e 90 DAT do segundo ciclo tiveram resultados variados e pouco conclusivos (Apêndices 8, 9 e 10).

Segundo Lauchli \& Epstein (1990), os problemas de salinidade se manifestam quando valores da $\mathrm{CE}_{\mathrm{es}}$ ultrapassam níveis acima dos tolerados pelas plantas ou quando há altas concentrações de certos íons em relação aos outros, podendo causar fitotoxicidade e deficiência induzida de alguns nutrientes presentes em baixas concentrações. Della Vecchia (1994) cita que a desordem nutricional pode ser causada pela absorção deficiente de cálcio devido ao manejo incorreto da irrigação ou ao desequilíbrio da adubação com potássio, magnésio e nitrogênio, que pode dificultar a absorção de cálcio.

\subsubsection{Evolução da salinidade do solo na zona radicular do meloeiro}

O acúmulo de sais no solo depende da qualidade da água de irrigação, das propriedades do solo e, principalmente, das condições de drenagem e do balanço de água e de sais no subsolo. Segundo Daker (1984), ligeiras diferenças na textura do solo podem provocar um movimento desigual na distribuição de água nas camadas do solo, acarretando sua desuniformidade na acumulação de sais ao longo do perfil. 
Nas Figuras 18 e 19 pode-se observar a distribuição das concentrações de sais ( $\mathrm{CE}_{\mathrm{es}}$ estimada a partir da $\mathrm{CE}_{1: 2}$ ) no perfil do solo aos 60 e 90 DAT do primeiro ciclo do meloeiro, em parcelas com níveis de salinidade $S_{1}, S_{3}$ e $S_{6}$, para os dois manejos da fertirrigação $\left(\mathrm{M}_{1}\right.$ e $\left.\mathrm{M}_{2}\right)$. Verifica-se nos níveis de salinidade $\mathrm{S}_{1}$ e $\mathrm{S}_{3}$, que as maiores concentrações de sais ocorreram na região próxima à superfície do solo e sob o gotejador, diminuindo com profundidade, havendo formação de isolinhas salinas bem definidas. Tal fato pode ser atribuído à alta freqüência de fertirrigação, bem como à maior evaporação e extração de água pelas plantas na camada superficial e próxima ao gotejador, como citam Hoffman et al. (1992). De acordo com Khan et al. (1996), a distribuição de solutos no solo aplicados via fertirrigação por gotejamento não acompanha exatamente a frente de avanço vertical da água, sendo que esta se movimenta um pouco à frente dos solutos, o que pode resultar no acúmulo de sais na zona radicular.

Para os perfis referentes ao tratamento de maior nível de salinidade $\left(\mathrm{S}_{6}\right)$, verificou-se um acúmulo de sais nas camadas mais profundas, provavelmente devido à deposição de sais precipitados nesta camada, ocorrida durante o processo de salinização artificial, e conseqüente solubilização destes no preparo da solução diluída para se determinar a $\mathrm{CE}_{1: 2}$.

A evolução dos perfis mostrou que houve um alargamento do bulbo com o tempo, com a salinidade aumentando para a periferia, sobretudo para o lado onde esteve localizado a planta, conforme verificado aos 90 DAT do primeiro ciclo (Figura 19). Isto acontece devido à ascensão e ao movimento lateral da solução salina, logo após a infiltração da água de irrigação na área central do bulbo, seguida da evaporação pela superfície do solo e extração de água pelas plantas, sendo a concentração de sais proporcional ao volume de água removido. Blanco (1999), Medeiros (1998), Gurgel (1999), Dias (2001) e Costa (1999), estudando o perfil transversal de distribuição de sais, também observaram que as maiores concentrações de salinidade ocorreram na região próxima a superfície, entre 15 e $20 \mathrm{~cm}$ do gotejador e também no lado em que estava a planta, correspondendo a área do sistema radicular. 

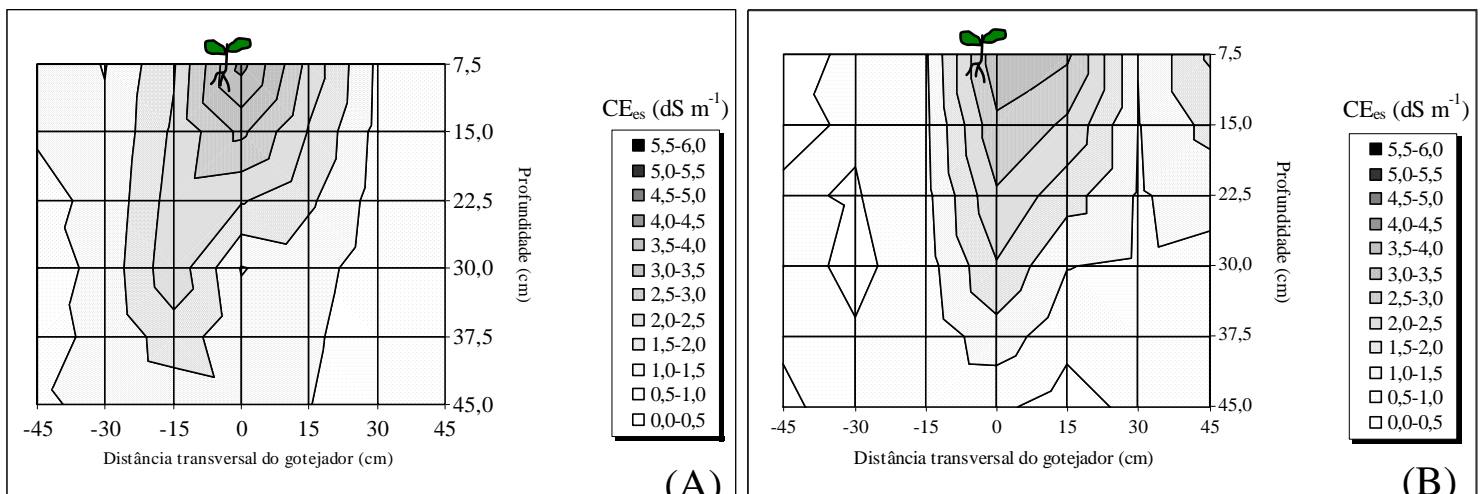

(A)
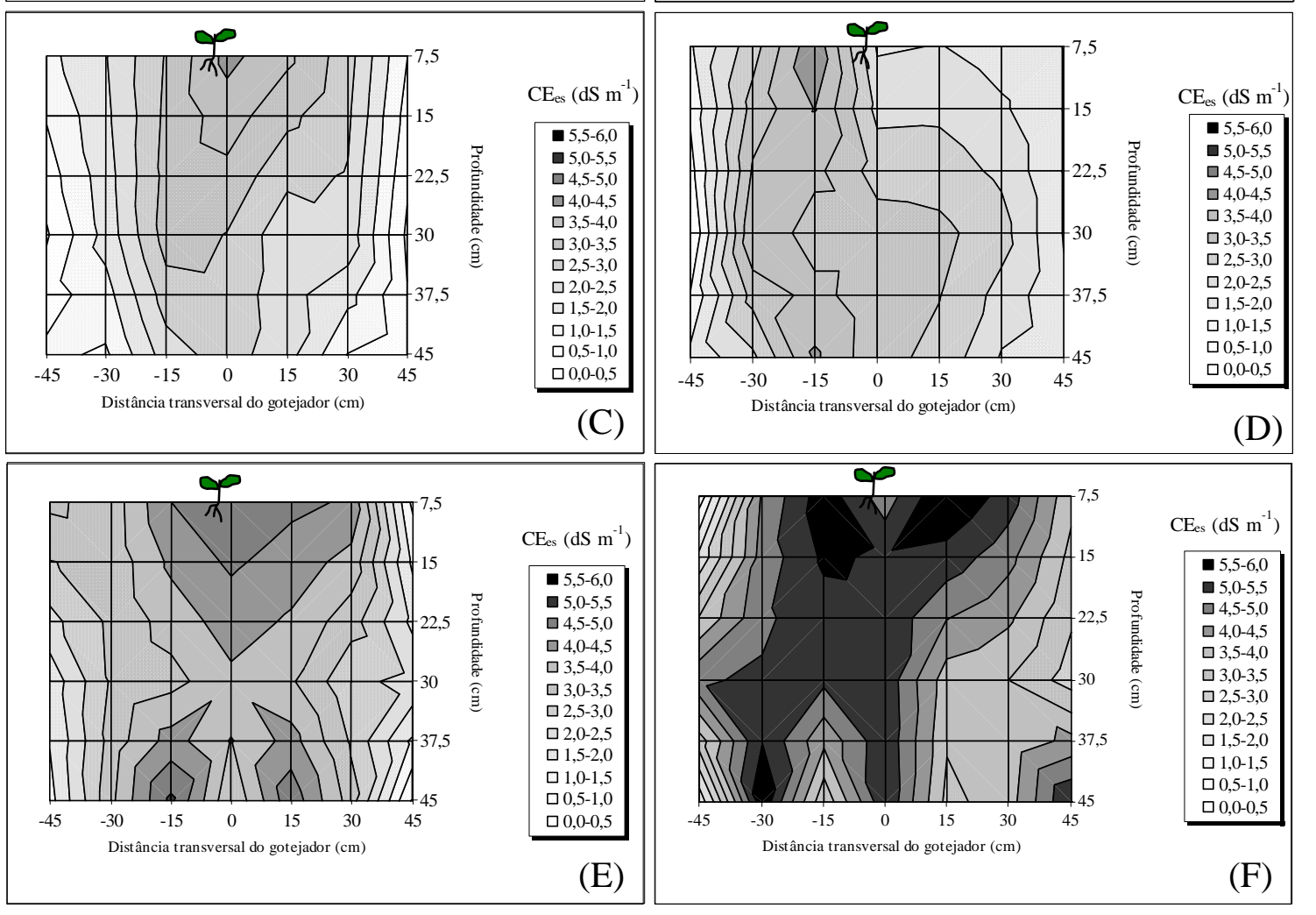

Figura 18 - Perfis transversais de salinidade do solo, medidos aos 60 DAT do $1^{\circ}$ ciclo para os tratamentos: $\mathrm{S}_{1} \mathrm{M}_{1}(\mathrm{~A}), \mathrm{S}_{1} \mathrm{M}_{2}$ (B), $\mathrm{S}_{3} \mathrm{M}_{1}$ (C), $\mathrm{S}_{3} \mathrm{M}_{2}$ (D), $\mathrm{S}_{6} \mathrm{M}_{1}$ (E), $\mathrm{S}_{6} \mathrm{M}_{2}$ (F) 


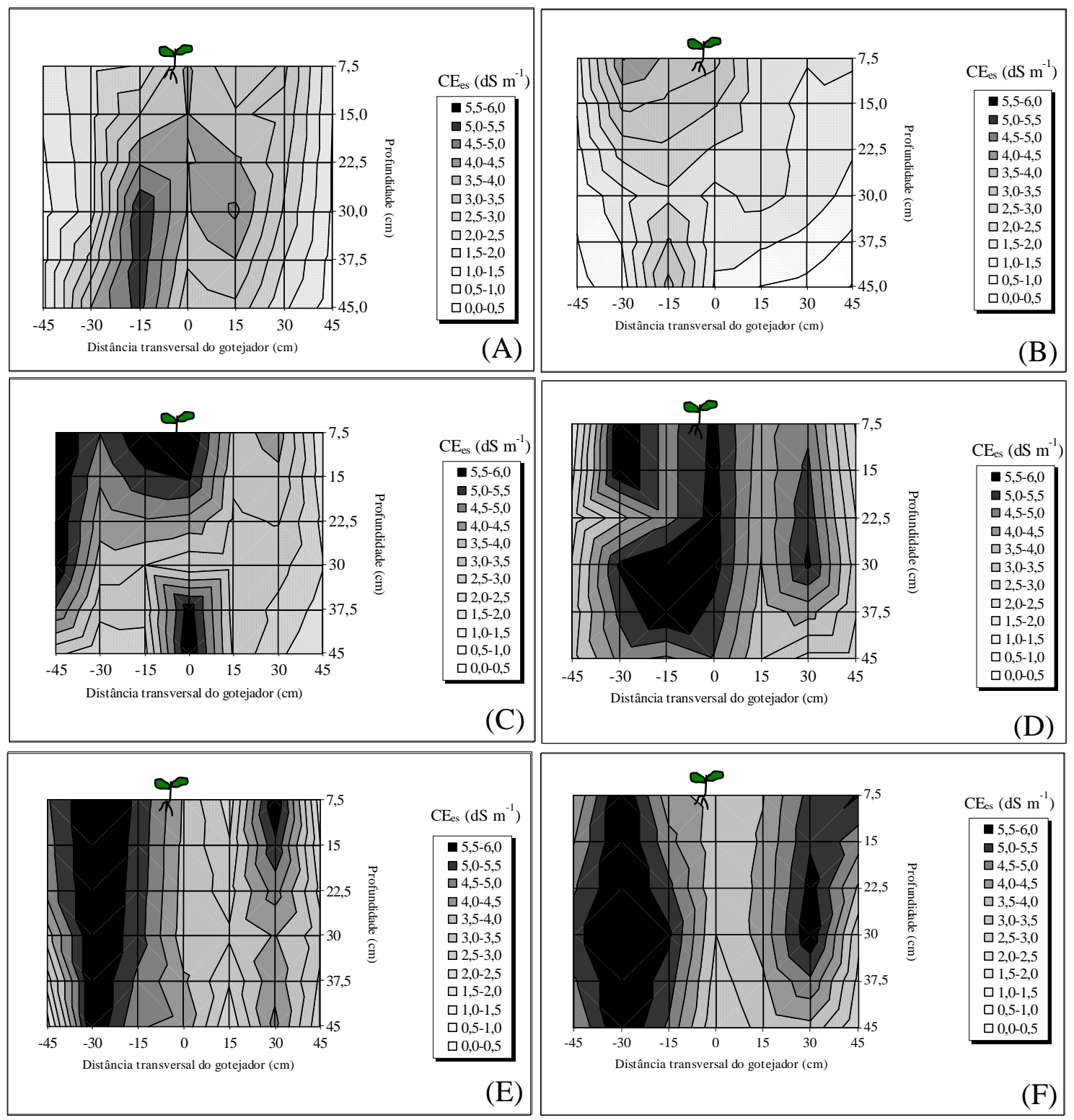

Figura 19 - Perfis transversais de salinidade do solo, medidos aos 60 DAT do $2^{\circ}$ ciclo para os tratamentos: $S_{1} M_{1}(A), S_{1} M_{2}(B), S_{3} M_{1}(C), S_{3} M_{2}$ (D), $S_{6} M_{1}$ (E), $\mathrm{S}_{6} \mathrm{M}_{2}(\mathrm{~F})$

De acordo com Ayres \& Westcot (1991), após se atingir o equilíbrio, a concentração de sais aumenta nas camadas mais profundas devido ao fato de que a água de irrigação evapotranspirada pela cultura deixa os sais na zona radicular para serem deslocados por irrigações subseqüentes para sua parte inferior, onde se acumulam até serem lixiviados a maiores profundidades. 
Com relação ao manejo da fertirrigação, pode-se verificar que no nível de salinidade S1 do manejo controlado houve menor variação de CE no perfil do solo quando comparada ao manejo tradicional, provavelmente, devido à menor quantidade de fertilizantes aplicados via água de irrigação para se manter a salinidade desejada. De modo contrário, a variação nos níveis de salinidade $\mathrm{S}_{3}$ e $\mathrm{S}_{6}$ do manejo controlado foram sempre maiores, pelo fato dos adubos aplicados para corrigir a CE ter contribuído para elevar a salinidade do solo, principalmente na periferia do bulbo.

\subsubsection{Potencial mátrico da água no solo}

Em solos salinos, o potencial osmótico é reduzido, resultando em uma menor absorção de água pelas plantas em decorrência da redução do potencial total da água no solo. Em conseqüência do menor consumo de água, ao se adotar um turno de rega fixo, espera-se uma menor variação na umidade do solo, a qual pode ser monitorada pela medição do potencial mátrico $\left(\phi_{\mathrm{m}}\right)$; isto porque este potencial descreve a contribuição das forças de retenção da solução no solo associadas com suas interfaces líquido-ar e sólido-líquido. Está, portanto, relacionado com a umidade do solo, sendo $\phi_{\mathrm{m}}$ tanto menor quanto mais seco estiver o solo (Libardi, 2000).

Os valores dos módulos do potencial mátrico $\left(\left|\phi_{\mathrm{m}}\right|\right)$, medidos no bulbo úmido a $20 \mathrm{~cm}$ de profundidade, para os diferentes níveis de salinidade inicial do solo e manejos da fertirrigação, ao longo do primeiro e do segundo ciclo do meloeiro são mostrados nas Figuras 20 e 21, respectivamente. Durante o primeiro ciclo, observam-se maiores valores do $\left|\phi_{\mathrm{m}}\right|$ nos níveis de menor salinidade, com grande variação entre as irrigações consecutivas, principalmente na fase de florescimento e frutificação (a partir de 74 DAT). Este comportamento não foi constatado no segundo ciclo, provavelmente devido o ataque severo de nematóides pertencentes à espécie Meloidogyne javanica (Apêndice 2) a partir do período de florescimento, reduzindo a absorção de água pelas plantas, resultando na menor variação diária do potencial.

É comum a redução do consumo de água pelas plantas quando ocorrem maiores níveis de salinidade, em razão dos efeitos negativos do potencial osmótico, acarretando 
em pequenas variações nos valores do $\left|\phi_{m}\right|$, o que indica baixa variação da umidade do solo.

As médias do $\left|\phi_{\mathrm{m}}\right|$ ao longo do primeiro ciclo variaram de 93 a 129 cm.c.a. para os tratamentos $S_{6} M_{2}$ e $S_{1} M_{2}$, respectivamente, o que corrobora com os resultados verificados por Medeiros (1998), Blanco (1999) e Dias (2001), os quais demonstraram que os valores do módulo do potencial mátrico foram menores a medida em que se aumentou a salinidade do solo, indicando baixa variação da umidade. Já durante o segundo ciclo, as médias do $\left|\phi_{\mathrm{m}}\right|$ variaram de 78 a 98 cm.c.a. para os tratamentos $\mathrm{S}_{6} \mathrm{M}_{2} \mathrm{e}$ $\mathrm{S}_{3} \mathrm{M}_{2}$, respectivamente. Entretanto, quando se compara os dois tipos do manejo da fertirrigação, verifica-se que não houve diferença sensível da variação do módulo do potencial mátrico entre os mesmos.

Os maiores valores do $\left|\phi_{\mathrm{m}}\right|$ ocorreram durante a fase de florescimento e frutificação (a partir de 74 e 48 DAT, para o primeiro e segundo ciclo, respectivamente), comprovando que a maior demanda de água requerida pela cultura ocorre durante essas fases. Em solos arenosos cultivados com hortaliças, Carrijo et al. (1999) recomenda para um bom desenvolvimento das culturas a manutenção de potencial mátrico na faixa de -150 a -100 cm.c.a. Considerando esta constatação, pode-se afirmar que para os dois ciclos consecutivos o manejo da irrigação proporcionou a manutenção da umidade suficiente para se atender a demanda hídrica da cultura do melão. 
(A)

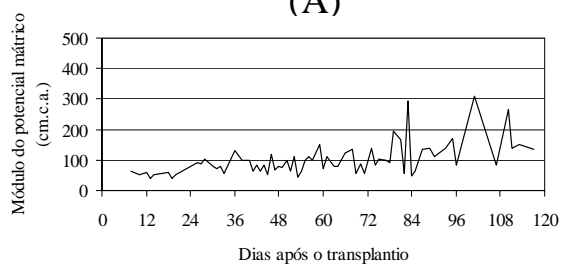

(C)

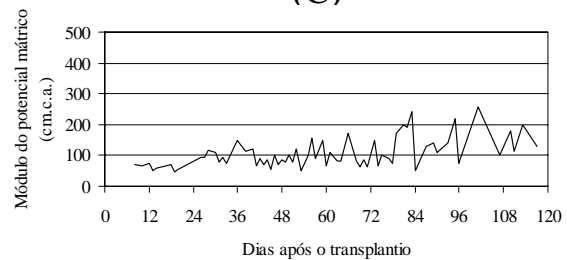

(E)

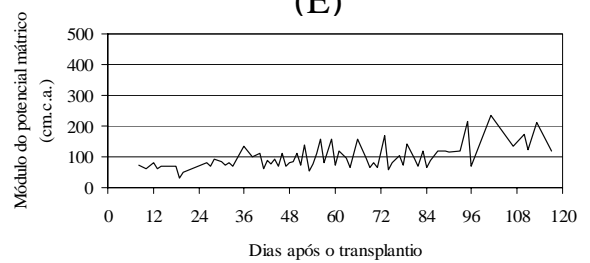

(G)

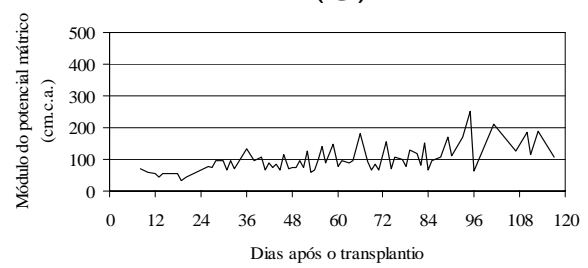

(I)

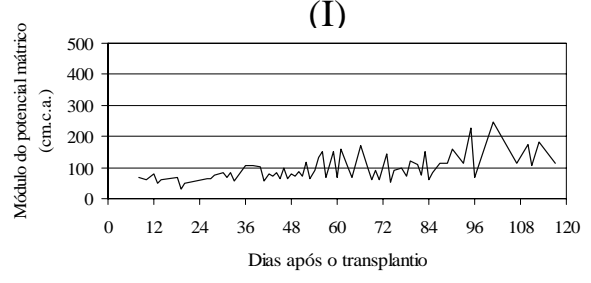

(L)

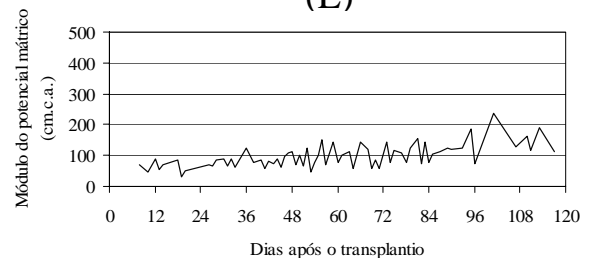

(B)

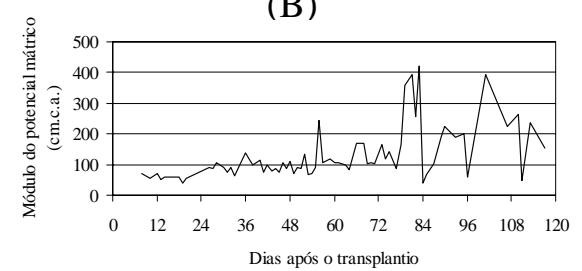

(D)

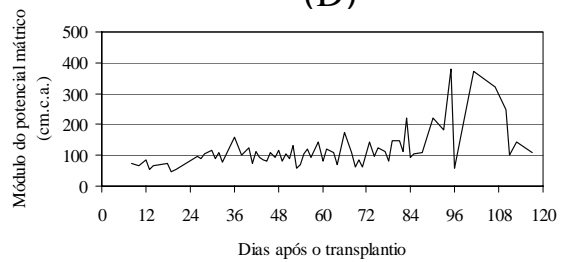

(F)

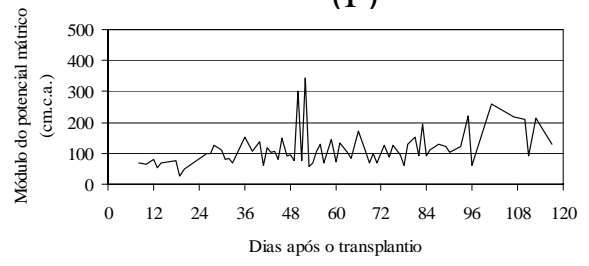

(H)

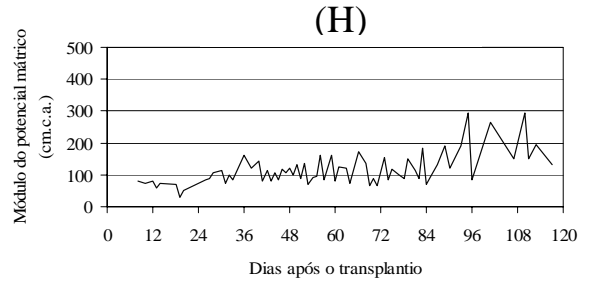

(J)

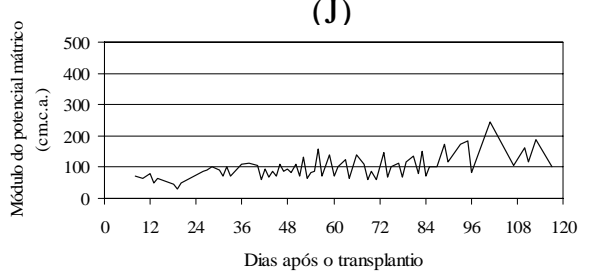

(M)

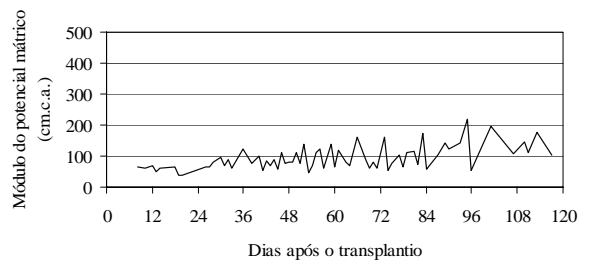

Figura 20 - Módulo do potencial mátrico, ao longo do $1^{\circ}$ ciclo, na profundidade de $20 \mathrm{~cm}$ para os tratamentos: $S_{1} M_{1}(A), S_{1} M_{2}(B), S_{2} M_{1}(C), S_{2} M_{2}$ (D), $S_{3} M_{1}$ (E), $S_{3} M_{2}$ $(F), S_{4} M_{1}(G)$ e $S_{4} M_{2}(H), S_{5} M_{1}(I), S_{5} M_{2}(J), S_{6} M_{1}(L)$ e $S_{6} M_{2}(M)$ 
(A)

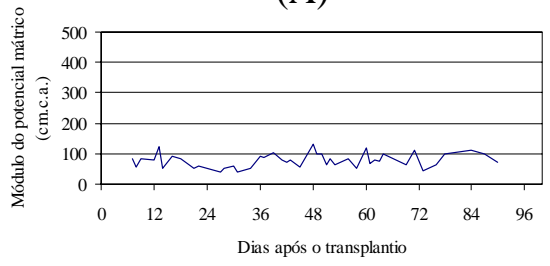

(C)

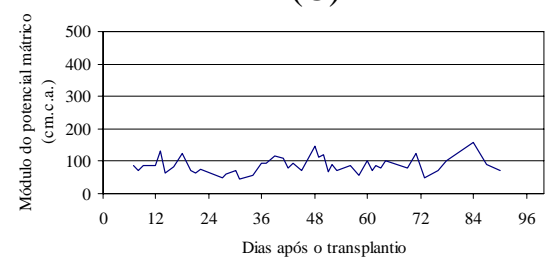

(E)

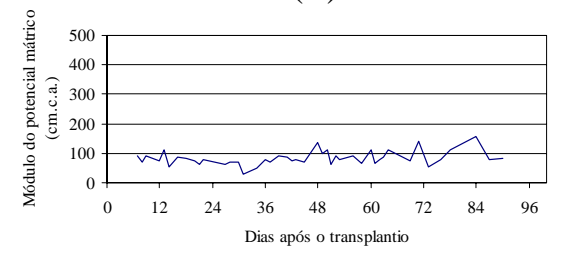

(G)

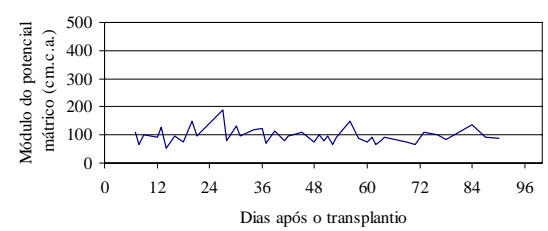

(I)

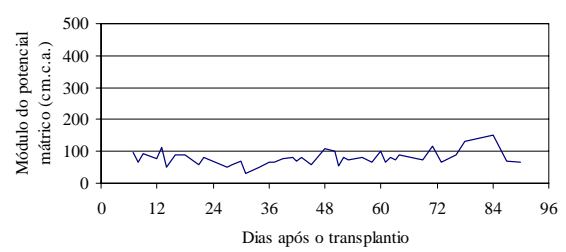

(L)

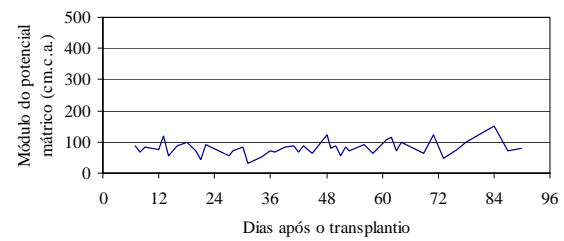

(B)

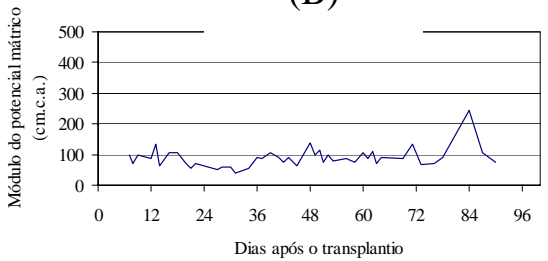

(D)

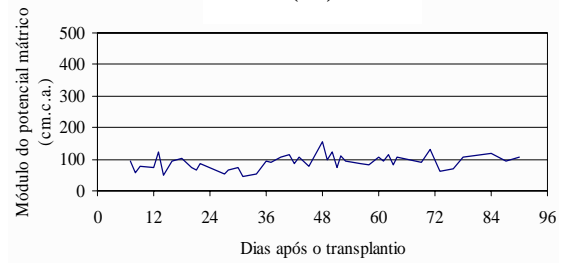

(F)

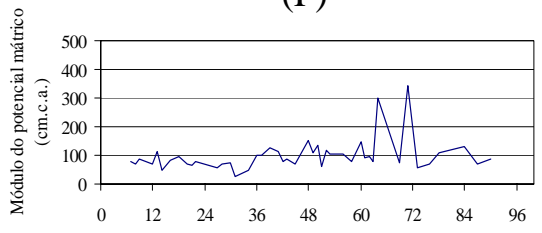

(H)

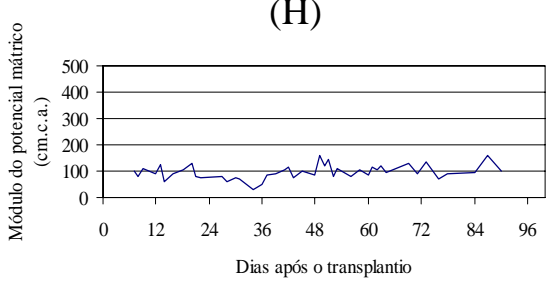

(J)

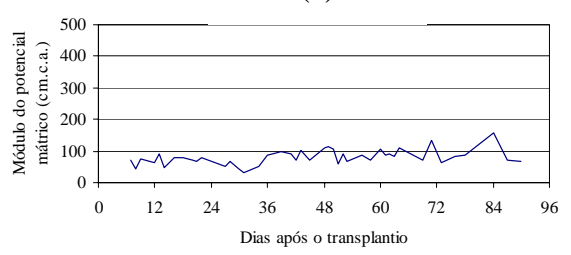

(M)

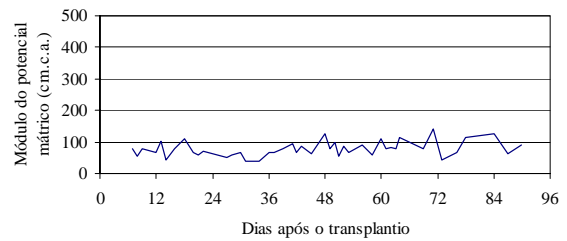

Figura 21 - Módulo do potencial mátrico, ao longo do $2^{\circ}$ ciclo, na profundidade de $20 \mathrm{~cm}$ para os tratamentos: $S_{1} M_{1}(A), S_{1} M_{2}$ (B), $S_{2} M_{1}$ (C), $S_{2} M_{2}$ (D), $S_{3} M_{1}(E), S_{3} M_{2}$ (F), $S_{4} M_{1}(G)$ e $S_{4} M_{2}(H), S_{5} M_{1}(I), S_{5} M_{2}(J), S_{6} M_{1}(L)$ e $S_{6} M_{2}(M)$ 


\subsubsection{Consumo de água sob estresse salino}

As lâminas de água aplicadas com a irrigação durante o primeiro ciclo para os diferentes níveis de salinidade inicial do solo e manejos da fertirrigação estão apresentadas na Figura 22 e Apêndice 11. Para o manejo tradicional não se verifica diferença sensível do consumo de água pelo sistema solo-planta entre os níveis salinidade inicial do solo. Entretanto, para o manejo controlado, verifica-se uma redução na lâmina de irrigação acumulada entre os níveis de salinidade, principalmente a partir de 50 DAT. Observa-se também que a diferença no consumo entre os níveis de salinidade aumenta com o tempo, sendo registrado maior decréscimo nos níveis de maior salinidade $\left(S_{5}\right.$ e $\left.S_{6}\right)$. Deve-se ressaltar que a quantidade de água transpirada pela planta nos primeiros dias após o transplantio (0-30 DAT) era possivelmente de ordem ínfima, quando comparada ao volume evaporado na superfície do solo, razão pela qual não foi constatada diferença apreciável de consumo, em função da salinidade, no referido período de aplicação.

Com relação ao segundo ciclo, verifica-se comportamento semelhante ao primeiro ciclo no que se refere aos efeitos dos níveis mais salinos na redução do consumo de água pela planta, porém com menores lâminas de água diárias e acumuladas aplicadas por irrigação durante as diferentes épocas (Figura 23 e Apêndice 12). Conforme já discutido, e de acordo com Rhoades \& Loveday (1990), a concentração de sais solúveis na zona radicular reduz o fluxo de água no sentido solo-planta-atmosfera, devido ao efeito osmótico na planta.

No manejo controlado, a diferença no consumo de água entre os níveis de salinidade é mais evidenciada, provavelmente devido à manutenção da salinidade do solo na zona radicular até o final do ciclo. 


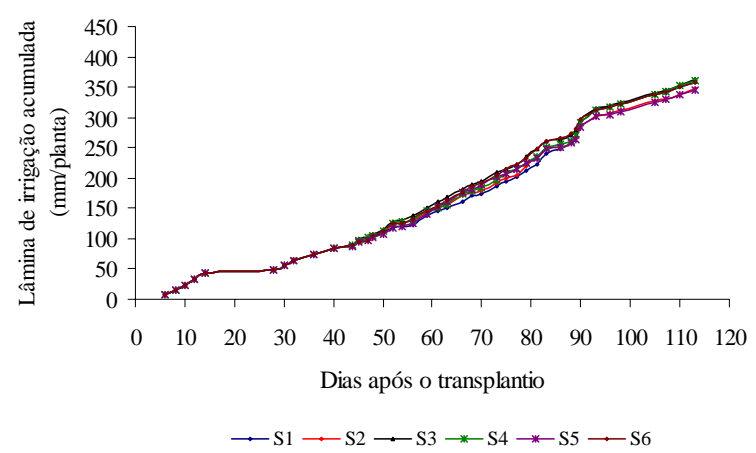

(A)

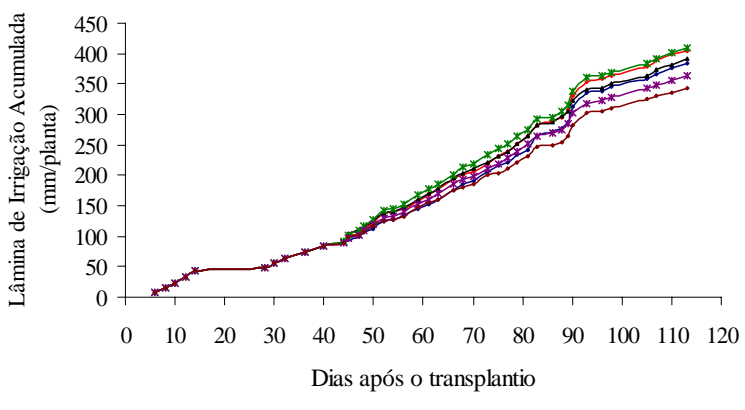

$\rightarrow \mathrm{S} 1 \rightarrow \mathrm{S} 2 \rightarrow \mathrm{S} 3 \rightarrow-\mathrm{S} 4 \rightarrow \mathrm{S} 5 \rightarrow \mathrm{S} 6$

(B)

Figura 22 - Lâmina de água acumulada aplicada com a irrigação durante o primeiro ciclo da cultura do melão para o manejo tradicional - $\mathrm{M}_{1}(\mathrm{~A})$ e manejo controlado $\mathrm{M}_{2}$ (B) da fertirrigação

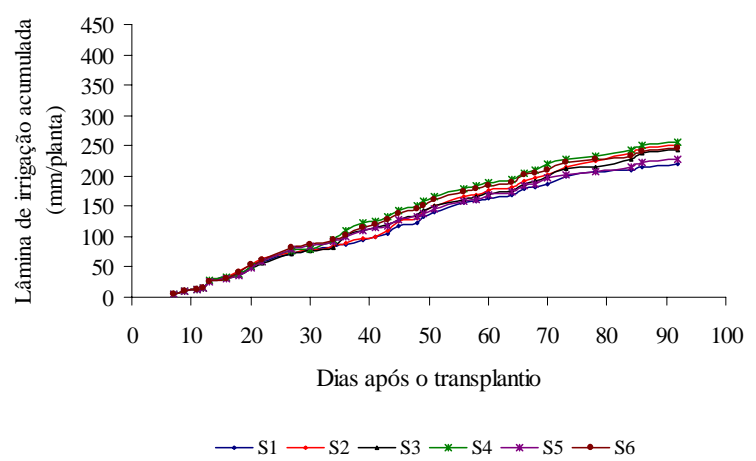

(A)

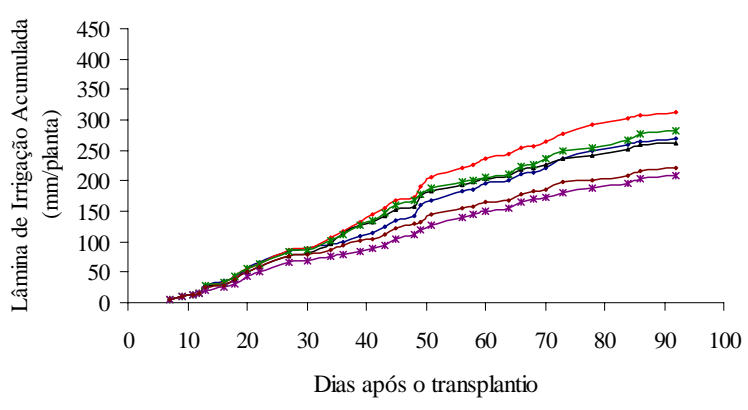

$\rightarrow \mathrm{S} 1 \rightarrow \mathrm{S} 2 \rightarrow \mathrm{S} 3 \rightarrow \mathrm{S} 4 \rightarrow \mathrm{S} 5 \rightarrow \mathrm{s} 6$

(B)

Figura 23 - Lâmina diária de água aplicada com a irrigação durante o segundo ciclo da cultura do melão para o manejo tradicional - $\mathrm{M}_{1}(\mathrm{~A})$ e manejo controlado $\mathrm{M}_{2}$ (B) da fertirrigação

As equações de regressão relativas ao consumo total de água em função do nível de salinidade do solo, ao final dos dois ciclos consecutivos do meloeiro estão dispostas na Figura 24. No manejo tradicional não houve um bom ajuste entre o consumo de água e os níveis de salinidade iniciais do solo nos dois ciclos do meloeiro. Já no manejo controlado da fertirrigação, verificou-se efeito quadrático significativo dos níveis de salinidade sobre o consumo da planta, com decréscimo no consumo hídrico a partir da 
$\mathrm{CE}_{\mathrm{es}}=2,76 \mathrm{dS} \mathrm{m}{ }^{-1}\left(\mathrm{R}^{2}=0,84\right)$ e da $\mathrm{CE}_{\mathrm{es}}=1,74 \mathrm{dS} \mathrm{m}^{-1}\left(\mathrm{R}^{2}=0,64\right)$, para o primeiro e o segundo ciclo, respectivamente, indicando que as plantas podem ter sofrido algum estresse hídrico induzido pelo estresse salino (seca fisiológica).

O efeito quadrático observado no consumo hídrico foi semelhante aos efeitos encontrados para as variáveis de crescimento da planta (altura e área foliar), conforme será relatado posteriormente, comprovando que o estresse salino induz ao menor consumo de água, como conseqüência da redução do crescimento. Resultados semelhantes também são apresentados por Hoffman (1985), Medeiros (1998), Soares (2001) e Silva (2002), os quais demonstraram que a redução relativa na evapotranspiração das plantas submetidas ao estresse salino correlaciona-se com a diminuição de biomassa.

Segundo Doorenbos \& Kassam (1994), existe uma relação direta entre a evapotranspiração e o crescimento, ou seja, a evapotranspiração é igual à máxima, e da mesma forma o crescimento, quando a necessidade hídrica da planta é plenamente satisfeita. De modo contrário, quando existe uma restrição hídrica, ocorre redução do crescimento, fato constatado no presente estudo, pois o aumento da $\mathrm{CE}_{\mathrm{es}}$ reduziu o consumo de água pelas plantas a partir de um determinado nível.

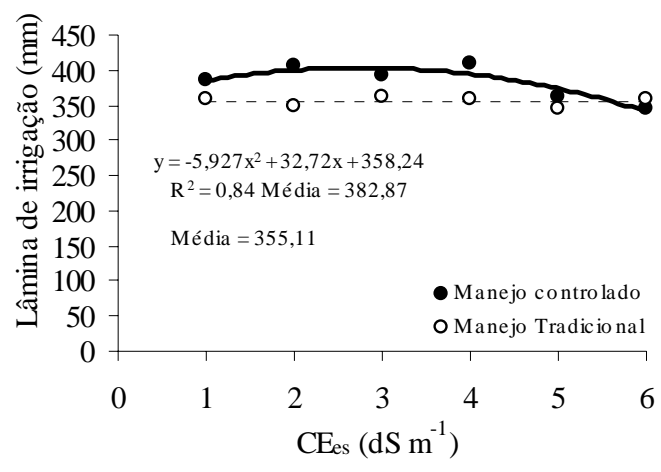

(A)

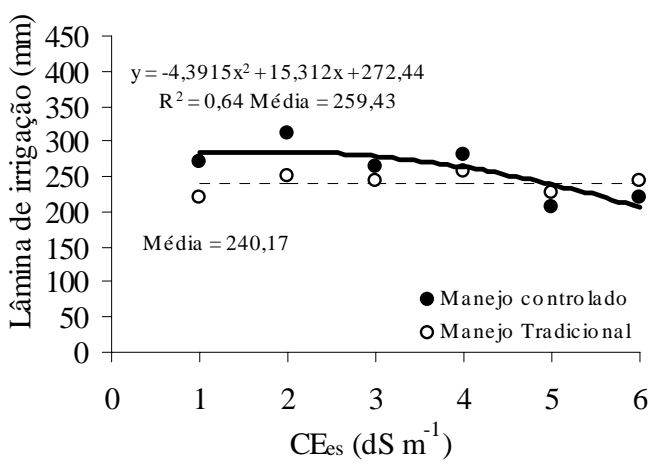

(B)

Figura 24 - Lâmina de água aplicada com irrigação em função dos níveis de salinidade para o primeiro (A) e segundo (B) ciclo 


\subsubsection{Crescimento de planta}

\section{Altura de planta}

Em relação a esta variável não foram observadas diferenças significativas entre os dois tipos de manejo da fertirrigação, de forma que os efeitos dos níveis de salinidade iniciais do solo foram avaliados para o $\mathrm{M}_{1}$ e $\mathrm{M}_{2}$ conjuntamente (Tabela 3 e 4).

A Figura 25 mostra o crescimento das plantas ao longo dos dois ciclos consecutivos, em função dos diferentes níveis de salinidade inicial do solo. Durante o primeiro ciclo, observam-se pequenas variações nas alturas de plantas até os 27 DAT, ocorrendo em seguida crescimento mais acentuado, com maior taxa entre 42 e 48 DAT. Aos 55 DAT, a maioria das plantas atingiu o último fio de arame da espaldeira, a 1,80 m de altura, ocasião em que se realizou a poda apical. No segundo ciclo, nota-se altas taxas de crescimento a partir dos 17 DAT, com maior taxa de crescimento entre 28 e 36 DAT, atingindo altura máxima aos 45 DAT.

Cardoso (2002) observou maior taxa de crescimento de plantas de meloeiro entre 17 e 24 DAT, sendo que até os 38 DAT a maioria das plantas já atingia altura máxima de poda apical. A baixa taxa de crescimento de plantas obtidas durante o primeiro ciclo do meloeiro deste trabalho pode ser atribuída às baixas temperaturas no ambiente protegido durante o ciclo, que estiveram entre e 4,9 $\mathrm{C}$ e $20,8^{\circ} \mathrm{C}$ (intervalo de ocorrência da temperatura mínima diária), faixa considerada insuficiente para o desenvolvimento e crescimento normal das plantas, o que provavelmente contribuiu para um ciclo mais longo (117 DAT).

Rizzo et al. (2000) encontraram altura média de plantas de melão Bônus 2 aos 45 DAT de 1,59 m, enquanto D’Albuquerque Júnior (2003), trabalhando com o mesmo híbrido de melão, no período de janeiro a março de 2003 em Piracicaba, encontrou altura média de 1,90 m aos 39 DAT, acima dos encontrados no presente experimento, para as mesmas fases de desenvolvimento, porém em épocas diferentes. 


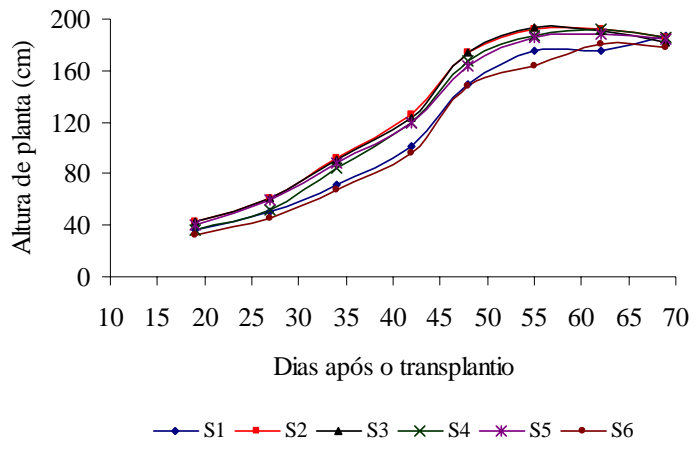

(A)

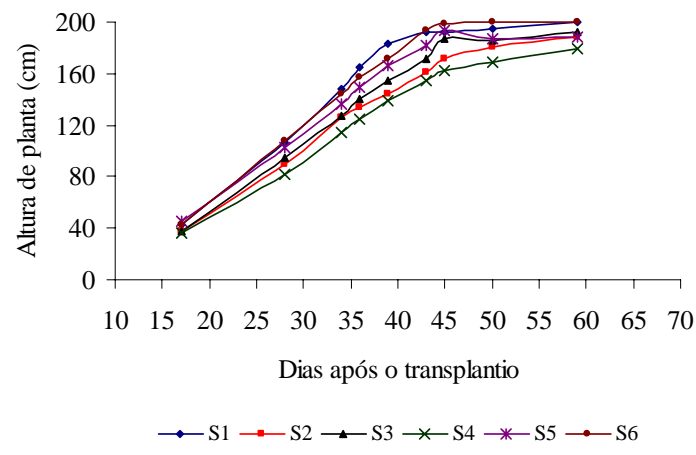

(B)

Figura 25 - Altura média de plantas ao longo do primeiro (A) e segundo (B) ciclo da cultura, para os diferentes níveis iniciais de salinidade do solo

Na Tabela 3 e 4 encontra-se os resumo da análise de variância para a variável altura de planta ao longo dos dois ciclos consecutivos do meloeiro. Verifica-se que houve efeito quadrático significativo $(\mathrm{p}<0,05)$ dos níveis iniciais de salinidade do solo sobre a altura das plantas até 62 DAT para o primeiro ciclo e a partir dos 28 DAT até os 59 DAT para o segundo ciclo. Entretanto, para os dois manejos da fertirrigação, em ambos os ciclos, conforme relatado anteriormente, a análise estatística demonstrou não haver influência deste fator sobre esta variável de crescimento, em nenhuma das medições efetuadas.

Analisando-se os estudos de regressão obtidos para o primeiro ciclo (Tabela 3), verificou-se efeito quadrático da salinidade sobre a altura das plantas, ao nível de $\mathrm{p}<0,05$ aos 19, 27 e 62 DAT e ao nível de p<0,01 para as demais épocas de amostragem. Segundo os modelos matemáticos obtidos (Figura 26), os efeitos da salinidade sobre a altura média das plantas foram mais severos durante o desenvolvimento inicial (19 DAT) do que no inicio da frutificação (62 DAT). No desenvolvimento inicial pode-se observar um decréscimo na altura a partir de 3,09 dS $\mathrm{m}^{-1}$, enquanto que no início da frutificação, a cultura tolera até $3,59 \mathrm{dS} \mathrm{m}^{-1}$ (ponto de máximo), sem prejuízos para o crescimento das plantas.

Segundo diversos autores, entre eles Dias et al. (2003), dentre as fases do ciclo da planta, a germinação e o desenvolvimento inicial são as mais sensíveis aos efeitos da 
salinidade e sua toxidez. Campos \& Assunção (1990) verificaram que o potencial osmótico de 1,2 MPa e os efeitos do íon de sódio, inibiram completamente a germinação das plântulas de arroz, cultivar IAC 25. Maas (1984) cita experimentos nos quais se verificou que o milho doce cultivado nos Estados Unidos, embora seja sensível durante o estágio inicial de crescimento, tolera até $9 \mathrm{dS} \mathrm{m} \mathrm{m}^{-1}$ durante o enchimento dos grãos, sem prejuízo de sua produtividade.

Tabela 3. Resumo da análise de variância para altura de plantas ao longo do primeiro ciclo do meloeiro, em função dos níveis de salinidade e manejo da fertirrigação

\begin{tabular}{lcccccccc}
\hline \multicolumn{1}{c}{ Fator } & \multicolumn{7}{c}{ Estatística F } \\
& 19 & 27 & 34 & 42 & 48 & 55 & 62 & 69 \\
\hline - Salinidade (S) & $2,04^{\mathrm{ns}}$ & $2,15^{\mathrm{ns}}$ & $3,08^{*}$ & $2,43^{*}$ & $3,32^{*}$ & $2,67^{*}$ & $1,47^{\mathrm{ns}}$ & $0,95^{\mathrm{ns}}$ \\
$\quad$ Linear & $1,42^{\mathrm{ns}}$ & $1,02^{\mathrm{ns}}$ & $0,56^{\mathrm{ns}}$ & $0,37^{\mathrm{ns}}$ & $0,60^{\mathrm{ns}}$ & $1,87^{\mathrm{ns}}$ & $0,13^{\mathrm{ns}}$ & $2,47^{\mathrm{ns}}$ \\
$\quad$ Quadrático & $4,71^{*}$ & $4,89^{*}$ & $10,99^{* *}$ & $9,67^{* *}$ & $13,80^{* *}$ & $10,23^{* *}$ & $6,25^{*}$ & $0,27^{\mathrm{ns}}$ \\
- Manejo (M) & $2,57^{\mathrm{ns}}$ & $1,25^{\mathrm{ns}}$ & $0,87^{\mathrm{ns}}$ & $0,37^{\mathrm{ns}}$ & $0,14^{\mathrm{ns}}$ & $0,001^{\mathrm{ns}}$ & $2,46^{\mathrm{ns}}$ & $2,04^{\mathrm{ns}}$ \\
S x M & $1,82^{\mathrm{ns}}$ & $2,02^{\mathrm{ns}}$ & $1,66^{\mathrm{ns}}$ & $1,45^{\mathrm{ns}}$ & $2,04^{\mathrm{ns}}$ & $1,22^{\mathrm{ns}}$ & $1,09^{\mathrm{ns}}$ & $0,62^{\mathrm{ns}}$ \\
CV (\%) & 22,22 & 23,59 & 20,24 & 18,96 & 11,27 & 10,49 & 8,52 & 5,18 \\
\hline ns Não significativo ao nível de 0,05 de probabilidade pelo teste F. & & & & & \\
* Significativo ao nível de 0,05 de probabilidade pelo teste F. \\
**Significativo ao nível de 0,01 de probabilidade pelo teste F.
\end{tabular}

Tabela 4. Resumo da análise de variância para altura de plantas ao longo do segundo ciclo do meloeiro, em função dos níveis de salinidade e manejo da fertirrigação

\begin{tabular}{|c|c|c|c|c|c|c|c|c|}
\hline \multirow[t]{2}{*}{ Fator } & \multicolumn{8}{|c|}{ Estatística F } \\
\hline & 17 & 28 & 34 & 39 & 43 & 45 & 50 & 59 \\
\hline - Salinidade (S) & $1,32^{\mathrm{ns}}$ & $2,00^{\mathrm{ns}}$ & $1,63^{\mathrm{ns}}$ & $2,51^{*}$ & $2,14^{\mathrm{ns}}$ & $2,82^{*}$ & $1,33^{\mathrm{ns}}$ & $1,16^{\mathrm{ns}}$ \\
\hline Linear & $0,81^{\mathrm{ns}}$ & $0,25^{\mathrm{ns}}$ & $0,005^{\mathrm{ns}}$ & $0,007^{\mathrm{ns}}$ & $0,32^{\mathrm{ns}}$ & $0,91^{\mathrm{ns}}$ & $0,14^{\mathrm{ns}}$ & $0,04^{\mathrm{ns}}$ \\
\hline Quadrático & $2,74^{\mathrm{ns}}$ & $6,85^{*}$ & $6,52 *$ & $8,78 * *$ & $7,84^{* *}$ & $6,19 *$ & $4,59 *$ & $4,22 *$ \\
\hline - Manejo (M) & $3,15^{\mathrm{ns}}$ & $1,24^{\mathrm{ns}}$ & $0,34^{\mathrm{ns}}$ & $0,21^{\mathrm{ns}}$ & $0,12^{\mathrm{ns}}$ & $1,65^{\mathrm{ns}}$ & $0,02^{\text {ns }}$ & $0,07^{\text {ns }}$ \\
\hline $\mathbf{S} \times \mathbf{M}$ & $1,02^{\mathrm{ns}}$ & $2,72^{\mathrm{ns}}$ & $0,75^{\mathrm{ns}}$ & $0,82^{\mathrm{ns}}$ & $0,92^{\mathrm{ns}}$ & $0,78^{\mathrm{ns}}$ & $0,77^{\mathrm{ns}}$ & $0,82^{\mathrm{ns}}$ \\
\hline CV (\%) & 22,86 & 21,35 & 20,52 & 18,80 & 17,65 & 13,11 & 14,01 & 10,60 \\
\hline
\end{tabular}




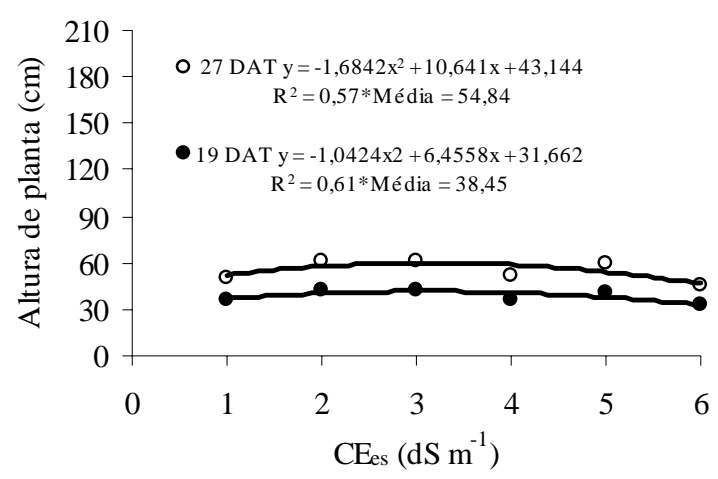

(A)

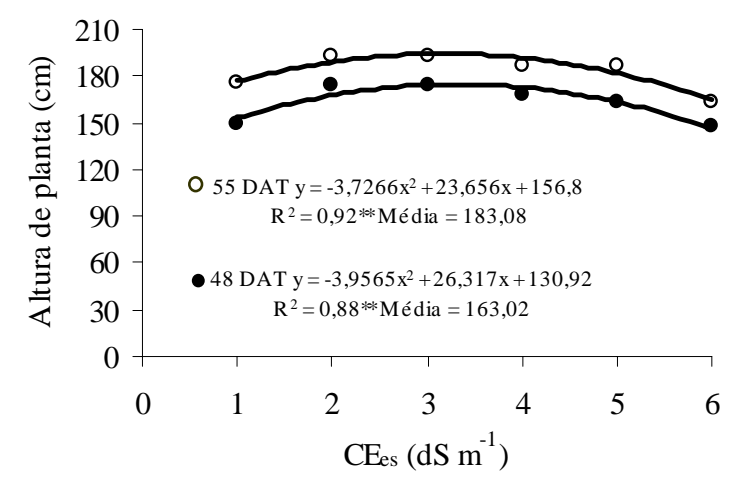

(C)

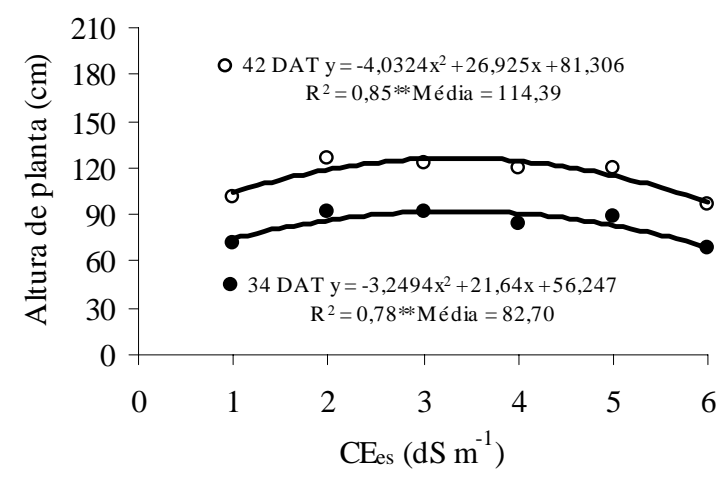

(B)

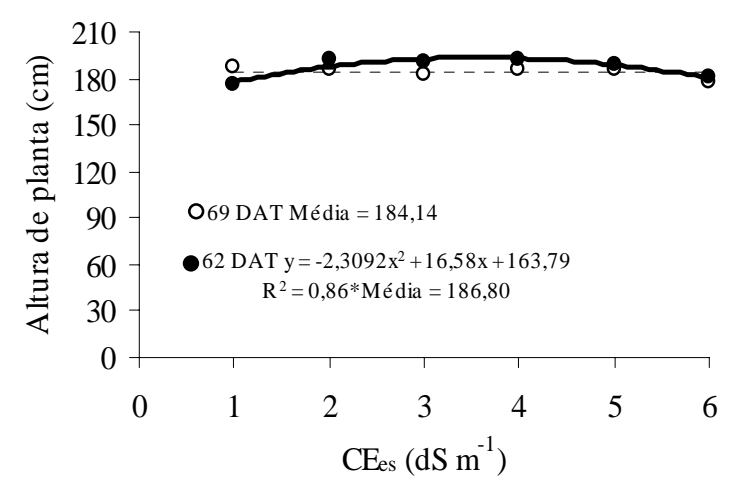

(D)

Figura 26 - Diagrama de dispersão e equação de ajuste entre a altura de plantas e os níveis de salinidade inicial do solo para o $1^{\circ}$ ciclo do meloeiro aos 19 e 27 DAT (A), aos 34 e 42 DAT (B), aos 48 e 55 DAT (C) e aos 62 e 69 DAT (D)

Ainda em relação à Figura 26, verificam-se bons coeficientes de determinação $\left(\mathrm{R}^{2}\right)$ a partir dos $42 \mathrm{DAT}$, os quais variaram de 0,85 a 0,92 , constatando-se alto grau de associação entre a salinidade inicial do solo ( $\left.\mathrm{CE}_{\text {es }}\right)$ e a altura das plantas, mostrando ser esta variável, muito sensível aos efeitos da salinidade. Outros autores como Blanco (1999) na cultura do pepino, Silva (2002) e Medeiros (1998) na cultura do pimentão também encontraram uma boa associação entre $\mathrm{CE}_{\mathrm{es}}$ e altura de planta. Para Hayward \& Wadleigh (1949) e Ayers \& Westcot (1991), a diminuição do potencial osmótico do 
substrato atua de forma negativa sobre o processo fisiológico, reduzindo a absorção de água pelas raízes, inibindo a atividade meristemática e o alongamento celular e, como conseqüência, causando redução no crescimento e desenvolvimento das plantas.

Observa-se na Tabela 4 que, no segundo ciclo, houve efeito quadrático da salinidade sobre a altura das plantas, ao nível de p<0,01 aos 39 e 43 DAT e ao nível de $\mathrm{p}<0,05$ para as demais épocas de amostragem, exceto aos 17 DAT, quando não houve influência significativa. De acordo com os modelos matemáticos obtidos (Figura 27), observou-se que em todas os períodos de amostragem, houve efeito quadrático, mas com curva de concavidade para cima, o que não tem sentido físico para o caráter do presente experimento.

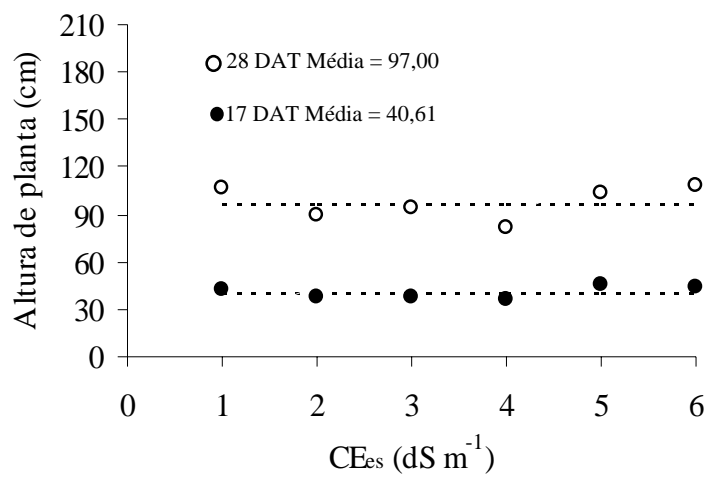

(A)

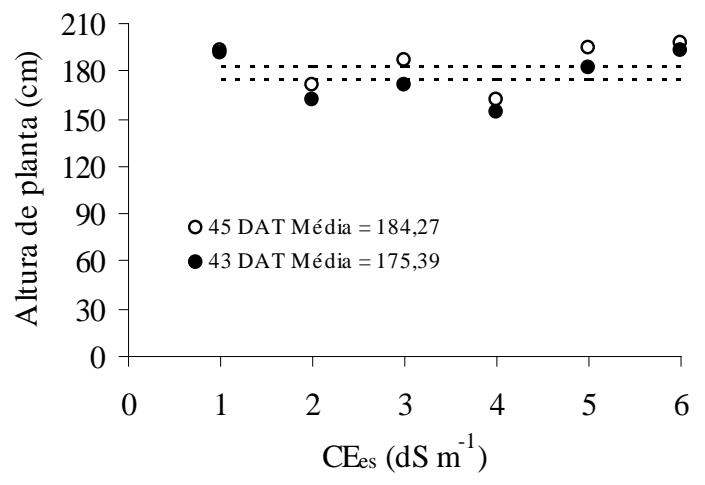

(C)

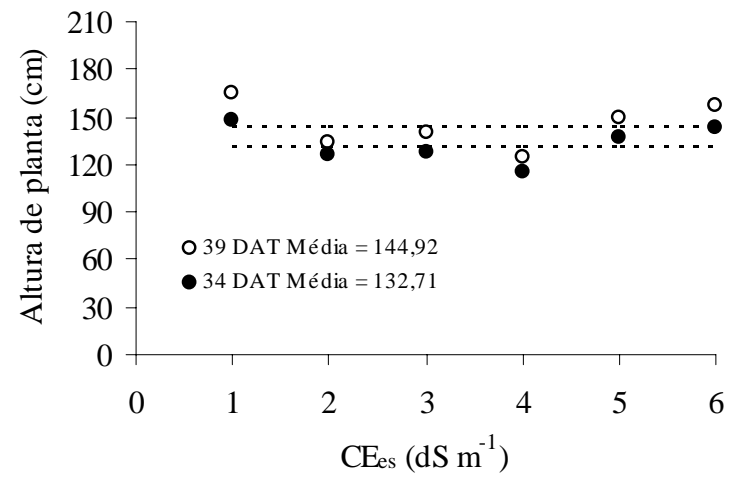

(B)

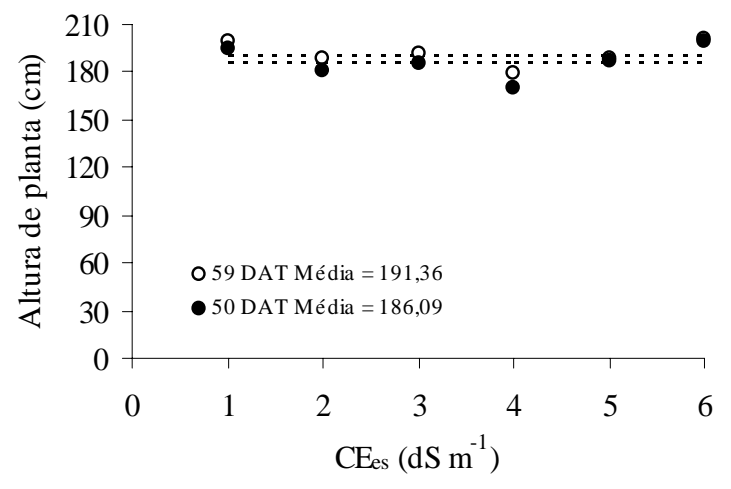

(D)

Figura 27 - Diagrama de dispersão e equação de ajuste entre a altura de plantas e os níveis de salinidade inicial do solo para o $2^{\circ}$ ciclo do meloeiro aos 17 e 28 DAT (A), aos 34 e 39 (B), aos 43 e 45 DAT (C) e aos 50 e 59 DAT (D) 
Considerando que a distribuição de temperatura do ar no ambiente protegido não é homogênea (Furlan, 2001), as plantas dos tratamentos $S_{2}$ e $S_{4}$, localizadas no centro do ambiente protegido, provavelmente receberam menor radiação solar em relação às demais plantas das parcelas localizadas na lateral (Figura 1) e, conseqüentemente, reduziram suas taxas de crescimento, independentemente do nível de salinidade a qual foram submetidas.

Isto explica em parte o comportamento das curvas de alturas de plantas em função salinidade com concavidade para cima no segundo ciclo do melão, uma vez que o meloeiro é exigente em temperatura. Segundo Seeman (1979), vários fatores influenciam a temperatura do ar no ambiente protegido tais como: ângulo de incidência da radiação solar, tipo de cobertura plástica, tipo de solo, tamanho e volume do ambiente protegido. Outra explicação provável é que a taxa de crescimento dos tratamentos $\mathrm{S}_{2}$ e $\mathrm{S}_{4}$ pode ter sido prejudicada por altas infestações de nematóide, conforme já relatado anteriormente, já que o ataque ocorreu de forma isolada ou em reboleira.

Bernstein (1964) relata que os sais presentes no solo podem afetar a altura da planta devido a efeitos osmótico, tóxico e de natureza nutricional. A menor absorção de água pelas plantas em condições salinas produz sintomas semelhantes aos de seca periódica, como por exemplo, murchamento temporário, queimaduras das folhas, coloração verde azulada, crescimento reduzido e folhas pequenas (Doorenbos \& Pruitt, 1977).

No presente experimento foram observadas queimaduras nas bordas e redução do tamanho das folhas em algumas plantas submetidas ao maior nível inicial de salinidade$\mathrm{S}_{6}$ (Figura 28), o que pode ser reflexo da interação salinidade $\mathrm{x}$ fertilidade, ou seja, a menor absorção de água pelas planta devido o efeito osmótico, associada ao desequilíbrio nutricional, fato comprovado nos estudos de Jurinak \& Wagenet (1981). 


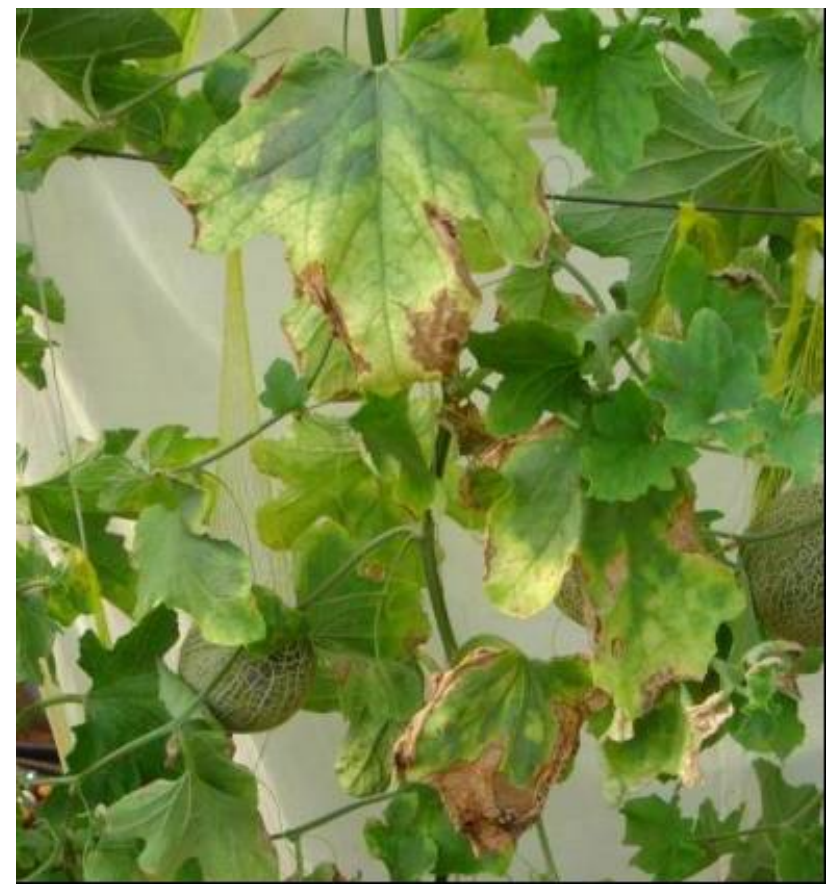

Figura 28 - Sintomas detectados em folhas de plantas cultivadas em níveis elevados de salinidade $\left(\mathrm{CE}_{\mathrm{es}}=6 \mathrm{dS} \mathrm{m}^{-1}\right)$ causada por excesso de fertilizantes

\section{Diâmetro do colo}

Na Figura 29 estão apresentados os valores médios do diâmetro do colo ao longo dos dois ciclos consecutivos do meloeiro. O diâmetro do colo das plantas aumentou constantemente até aos 48 e 43 DAT, para o primeiro e segundo ciclo, respectivamente, sendo que após estes períodos houve redução considerada no ritmo de crescimento do diâmetro do colo, mantendo-se o mesmo praticamente constante. Os valores dos diâmetros do colo variaram entre os níveis de salinidade ao longo dos dois cultivos do meloeiro, observando-se maior decréscimo no nível de salinidade 6 e 4 dS m m $^{-1}$ para o primeiro e segundo ciclo, respectivamente.

Como pode ser observado na Tabela 5 e 6, o diâmetro do colo foi afetado linearmente pela salinidade inicial do solo em todas as medições efetuadas ao longo dos dois ciclos consecutivos, exceto para a medição realizada aos 59 DAT do segundo ciclo. Além disso, pode-se verificar também o efeito quadrático dos níveis de salinidade sobre o diâmetro do colo para as leituras realizadas aos 39 e 45 DAT do segundo ciclo. 
Somente aos 34 DAT do primeiro ciclo houve efeito do manejo da fertirrigação sobre o diâmetro do colo, ao nível de $\mathrm{p}<0,01$, em que se verificou um acréscimo de 9,54 \% no diâmetro médio das plantas do manejo $\mathrm{M}_{2}$ em relação ao manejo $\mathrm{M}_{1}$.

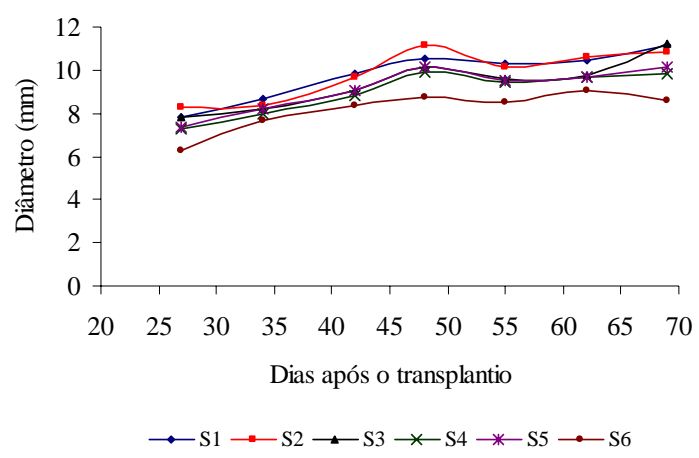

(A)

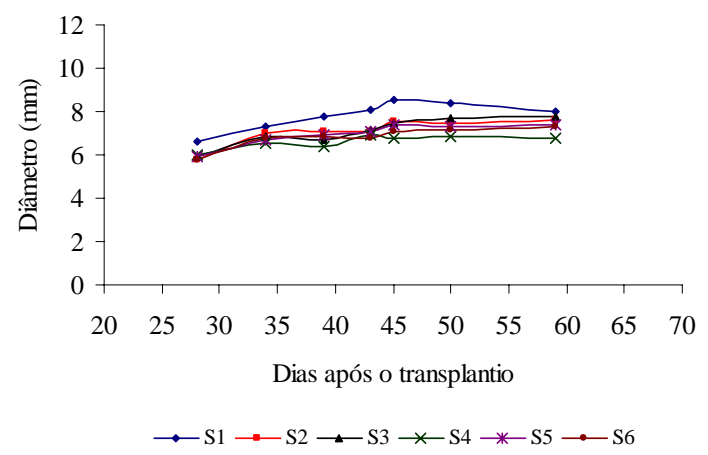

(B)

Figura 29 - Diâmetro de colo ao longo do primeiro (A) e do segundo (B) ciclo da cultura para os diferentes níveis iniciais de salinidade do solo

As regressões do diâmetro de colo em função do nível inicial de salinidade do solo, ao longo do primeiro ciclo, estão dispostas na Figura 30. Em todas as épocas de avaliação, o diâmetro decresceu linearmente com o aumento da salinidade do solo, com decréscimo relativo entre $S_{1}$ e $S_{6}$ de 19,23, 9,23, 13,71, 15,88, 14,88, 13,36 e 20,34 \% aos 27, 34, 42, 48, 55, 62 e 69 DAT, respectivamente.

De maneira semelhante ao primeiro ciclo, a variável diâmetro do colo entre 28 e 50 DAT também decresceu linearmente com o aumento do nível de salinidade do solo no segundo ciclo (Figura 31), porém com baixos valores de coeficientes de determinação $\left(R^{2}\right)$ em todas as épocas de amostragem, variando entre 0,41 e 0,64. 
Tabela 5. Resumo da análise de variância para o diâmetro de colo ao longo do primeiro ciclo do meloeiro, em função dos níveis de salinidade e dos manejos da fertirrigação

\begin{tabular}{|c|c|c|c|c|c|c|c|}
\hline \multirow[t]{2}{*}{ Fator } & \multicolumn{7}{|c|}{$\begin{array}{c}\text { Estatística F } \\
\text { Dias após o transplantio }\end{array}$} \\
\hline & 27 & 34 & 42 & 48 & 55 & 62 & 69 \\
\hline - Salinidade (S) & $3,69 * *$ & $1,04^{\mathrm{ns}}$ & $1,89^{\mathrm{ns}}$ & $2,67^{*}$ & $3,36^{*}$ & $2,64^{*}$ & $3,49 *$ \\
\hline Linear & $14,19 * *$ & $4,48^{*}$ & $7,77 * *$ & $8,86^{* *}$ & $13,84^{* *}$ & $11,25 * *$ & $14,50 * *$ \\
\hline Quadrático & $2,46^{\mathrm{ns}}$ & $0,026^{\mathrm{ns}}$ & $0,12^{\mathrm{ns}}$ & $1,01^{\mathrm{ns}}$ & $0,21^{\mathrm{ns}}$ & $0,004^{\mathrm{ns}}$ & s $0,83^{\mathrm{ns}}$ \\
\hline - Manejo (M) & $1,49^{\mathrm{ns}}$ & $7,09 *$ & $0,95^{\mathrm{ns}}$ & $0,74^{\mathrm{ns}}$ & $1,25^{\mathrm{ns}}$ & $0,25^{\mathrm{ns}}$ & $1,19^{\mathrm{ns}}$ \\
\hline $\mathbf{S} \times \mathbf{M}$ & $0,81^{\mathrm{ns}}$ & $1,21^{\mathrm{ns}}$ & $1,01^{\mathrm{ns}}$ & $0,54^{\mathrm{ns}}$ & $0,023^{\mathrm{ns}}$ & $0,37^{\mathrm{ns}}$ & $0,40^{\mathrm{ns}}$ \\
\hline CV (\%) & 13,32 & 11,66 & 11,96 & 13,30 & 10,28 & 9,97 & 13,43 \\
\hline
\end{tabular}

Tabela 6. Resumo da análise de variância para o diâmetro de colo ao longo do segundo ciclo do meloeiro, em função dos níveis de salinidade e dos manejos da fertirrigação

\begin{tabular}{lccccccc}
\hline \multirow{2}{*}{ Fator } & \multicolumn{7}{c}{ Estatística F } \\
& 28 & 34 & 39 & 43 & 45 & 50 & 59 \\
\hline - Salinidade (S) & $2,68^{*}$ & $1,70^{\mathrm{ns}}$ & $2,40^{\mathrm{ns}}$ & $2,71^{*}$ & $3,29^{*}$ & $2,15^{\mathrm{ns}}$ & $1,42^{\mathrm{ns}}$ \\
$\quad$ Linear & $5,70^{*}$ & $5,39^{*}$ & $4,81^{*}$ & $8,38^{* *}$ & $9,10^{* *}$ & $6,05^{*}$ & $2,80^{\mathrm{ns}}$ \\
$\quad$ Quadrático & $1,95^{\mathrm{ns}}$ & $2,28^{\mathrm{ns}}$ & $5,89^{* *}$ & $2,57^{\mathrm{ns}}$ & $4,05^{*}$ & $1,95^{\mathrm{ns}}$ & $1,40^{\mathrm{ns}}$ \\
- Manejo (M) $_{\text {S x M }}$ & $0,95^{\mathrm{ns}}$ & $0,64^{\mathrm{ns}}$ & $0,001^{\mathrm{ns}}$ & $0,31^{\mathrm{ns}}$ & $0,015^{\mathrm{ns}}$ & $0,56^{\mathrm{ns}}$ & $0,31^{\mathrm{ns}}$ \\
$\mathbf{C V ~ ( \% ) ~}$ & $0,54^{\mathrm{ns}}$ & $0,85^{\mathrm{ns}}$ & $0,74^{\mathrm{ns}}$ & $2,39^{\mathrm{ns}}$ & $1,16^{\mathrm{ns}}$ & $0,75^{\mathrm{ns}}$ & $1,47^{\mathrm{ns}}$ \\
\hline
\end{tabular}

ns Não significativo ao nível de 0,05 de probabilidade pelo teste $\mathrm{F}$.

* Significativo ao nível de 0,05 de probabilidade pelo teste F.

**Significativo ao nível de 0,01 de probabilidade pelo teste F. 


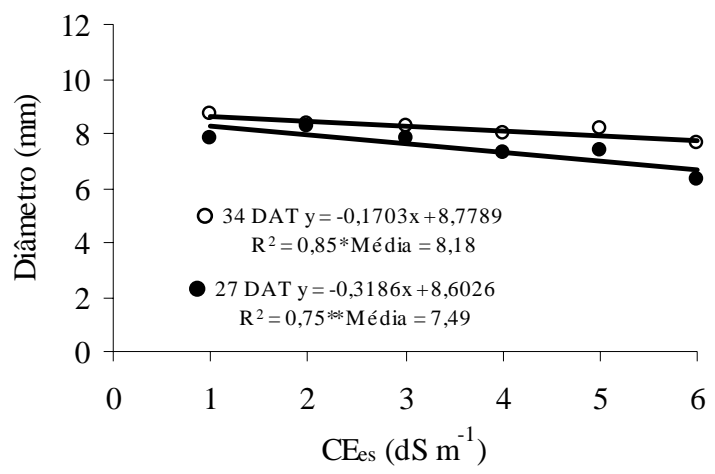

(A)

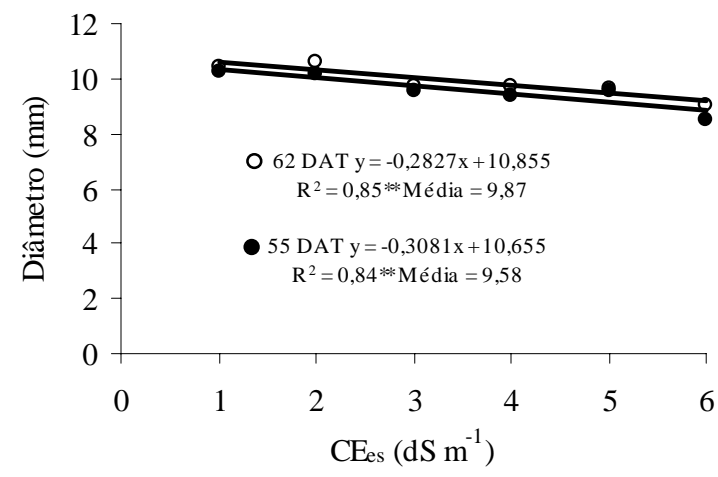

(C)

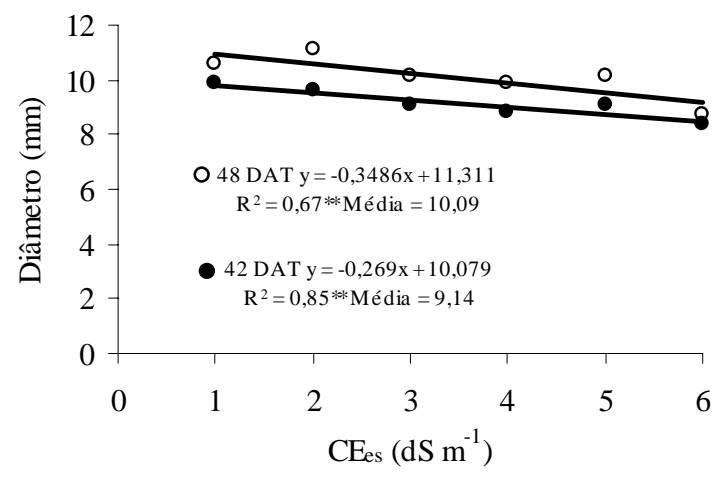

(B)

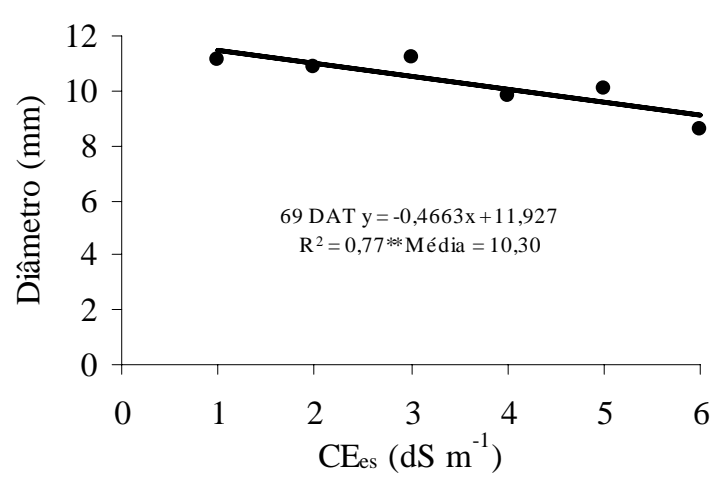

(D)

Figura 30 - Diagrama de dispersão e equação de ajuste entre o diâmetro do colo e os níveis de salinidade inicial do solo para o primeiro ciclo do meloeiro aos 27 e 34 DAT (A), aos 42 e 48 DAT (B), aos 55 e 62 DAT (C) e aos 69 DAT (D) 


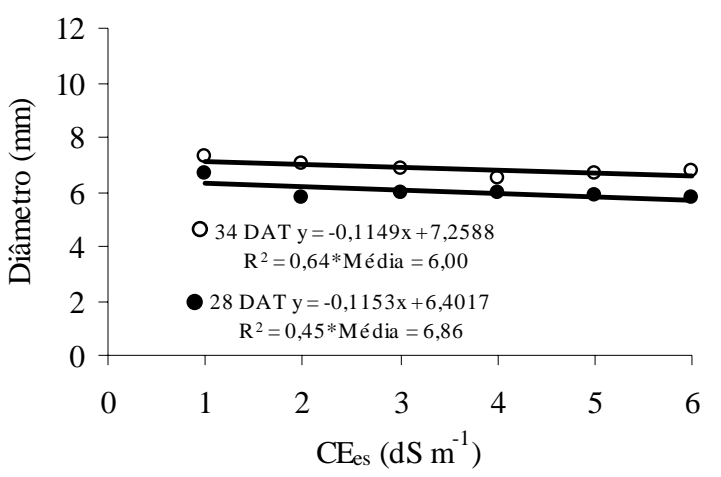

(A)

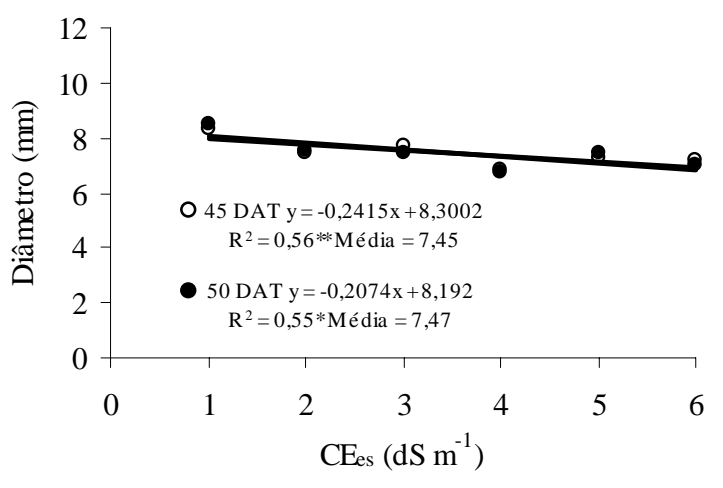

(C)

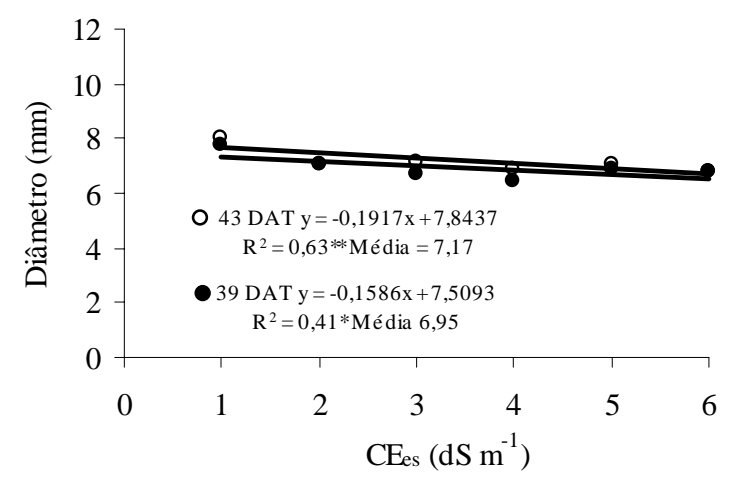

(B)

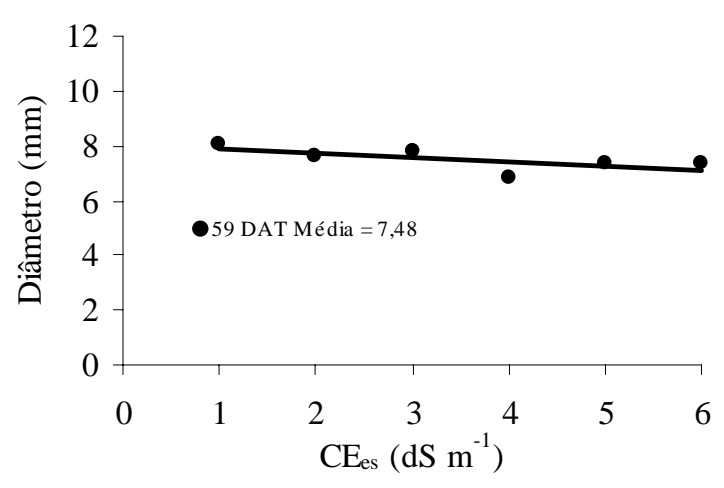

(D)

Figura 31 - Diagrama de dispersão e equação de ajuste entre o diâmetro do colo e os níveis de salinidade inicial do solo para o segundo ciclo do meloeiro aos 28 e 34 DAT (A), aos 39 e 43 DAT (B), 45 e 50 DAT (C) e 59 DAT (D)

\section{Área foliar}

Os resultados obtidos para a área foliar nos dois ciclos consecutivos do meloeiro encontram-se na Tabela 7 e Figura 32. A área foliar (AF) sofreu os efeitos da salinidade inicial do solo apenas durante o primeiro ciclo, sendo o modelo quadrático o que melhor se adaptou. Para o segundo ciclo não foram observadas diferenças significativas da salinidade do solo. Também não foram observadas diferenças para o fator manejo, exceto na coleta realizada 50 DAT (Tabela 7). Neste caso a AF apresentada por $\mathrm{M}_{1}$ e $\mathrm{M}_{2}$ foram, respectivamente, 0,682 e $0,504 \mathrm{~m}^{2}$. 
Tabela 7. Resumo da análise de variância para a área foliar ao longo dos dois ciclos consecutivos do meloeiro, em função dos níveis de salinidade e do manejo da fertirrigação

\begin{tabular}{|c|c|c|c|c|c|c|c|c|}
\hline \multirow{4}{*}{ Fator } & \multicolumn{8}{|c|}{ Dias após a transplantio - DAT } \\
\hline & \multicolumn{4}{|c|}{ Ciclo 1} & \multicolumn{4}{|c|}{ Ciclo 2} \\
\hline & 34 & 57 & 78 & 92 & 17 & 37 & 50 & 72 \\
\hline & \multicolumn{8}{|c|}{ Estatística F } \\
\hline - Salinidade (S) & $2,72^{*}$ & $1,71^{\mathrm{ns}}$ & $2,13^{\mathrm{ns}}$ & $5,47 * *$ & $1,05^{\mathrm{ns}}$ & $0,30^{\mathrm{ns}}$ & $0,17^{\mathrm{ns}}$ & $0,49^{\mathrm{ns}}$ \\
\hline Linear & $3,46^{\mathrm{ns}}$ & $0,21^{\mathrm{ns}}$ & $3,21^{\mathrm{ns}}$ & $16,26 * *$ & $0,51^{\mathrm{ns}}$ & $0,52^{\mathrm{ns}}$ & $0,11^{\mathrm{ns}}$ & $0,23^{\mathrm{ns}}$ \\
\hline Quadrático & $4,20 *$ & $6,35^{*}$ & $5,63 *$ & $9,52 * *$ & $0,75^{\mathrm{ns}}$ & $0,96^{\mathrm{ns}}$ & $0,18^{\mathrm{ns}}$ & $0,72^{\mathrm{ns}}$ \\
\hline - Manejo (M) & $2,80^{\mathrm{ns}}$ & $0,04^{\mathrm{ns}}$ & $0,42^{\mathrm{ns}}$ & $2,64^{\mathrm{ns}}$ & $0,09^{\mathrm{ns}}$ & $2,68^{\mathrm{ns}}$ & $6,22 *$ & $0,79^{\mathrm{ns}}$ \\
\hline $\mathbf{S} \times \mathbf{M}$ & $1,32^{\mathrm{ns}}$ & $1,83^{\mathrm{ns}}$ & $0,64^{\mathrm{ns}}$ & $1,34^{\mathrm{ns}}$ & $2,72^{\mathrm{ns}}$ & $2,93 *$ & $1,41^{\mathrm{ns}}$ & $0,83^{\text {ns }}$ \\
\hline CV (\%) & 35,54 & 24,09 & 22,57 & 21,73 & 25,95 & 34,07 & 41,78 & 40,34 \\
\hline
\end{tabular}

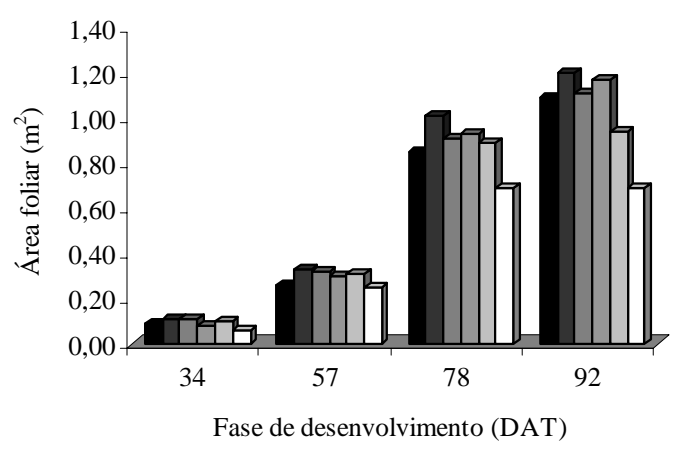

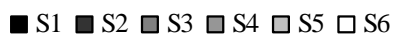

(A)

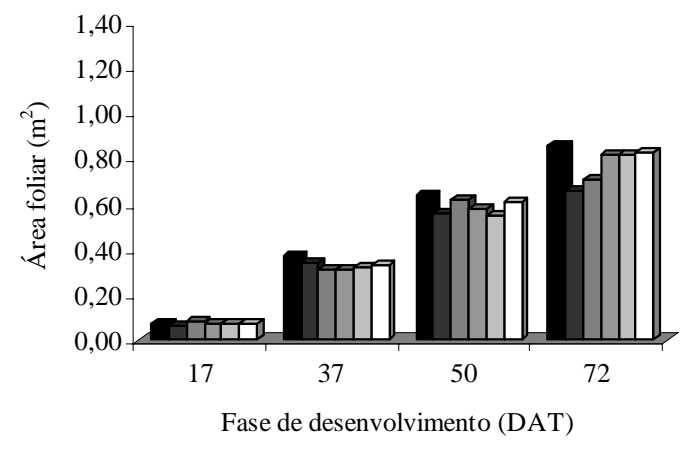

$\square \mathrm{S} 1 \square \mathrm{S} 2 \square \mathrm{S} 3 \square \mathrm{S} 4 \square \mathrm{S} 5 \square \mathrm{S} 6$

(B)

Figura 32 - Crescimento de área foliar em diferentes épocas de desenvolvimento durante o primeiro (A) e o segundo (B) ciclo da cultura do meloeiro, para cada nível salinidade inicial do solo

Analisando-se cada nível de salinidade, verifica-se um incremento da AF ao longo do tempo; porém no primeiro ciclo, o efeito osmótico praticamente cessou o crescimento da AF das plantas dos níveis salinos mais elevados no período compreendido entre 78 e 92 DAT, com incremento de apenas 0,051 $\mathrm{m}^{2}$ (0,8876 para 0,9386) e $0,0033 \mathrm{~m}^{2}(0,6915$ para 0,6948$)$ para os níveis $\mathrm{S}_{5}$ e $\mathrm{S}_{6}$, respectivamente. 
A AF máxima obtida na fase reprodutiva (92 DAT) do primeiro ciclo foi de 1,2027 $\mathrm{m}^{2}$, sendo inferior aos valores encontrados por Cardoso (2002) no período de outubro a dezembro de 2001 e D’Albuquerque Júnior (2003) no período de janeiro a março 2002, que obtiveram neste mesmo estádio de desenvolvimento valores máximos de AF de 1,693 $\mathrm{m}^{2}$ e 2,006 $\mathrm{m}^{2}$, respectivamente. Tal fato está possivelmente relacionado às baixas temperaturas ocorridas no ambiente protegido durante o primeiro ciclo.

Conforme já relatado, verifica-se com base na análise da variância (Tabela 7) que, para o primeiro ciclo houve efeito quadrático $(p<0,05)$ da salinidade inicial do solo sobre a AF em todas as épocas de avaliação. De acordo com as equações de regressão (Figura 33), observa-se que a AF, para os diferentes níveis de salinidade, apresentou um ajuste que permite o cálculo de pontos de máximo que ocorrem para 2,84, 3,31, 2,95 e 2,57 dS m $\mathrm{m}^{-1}$ aos 34, 57, 78 e 92 DAT, respectivamente. Segundo Maas \& Hoffman (1977), o aumento da concentração salina da solução do solo acima do limite tolerável pelas culturas diminui progressivamente o seu percentual de crescimento. $\mathrm{O}$ aumento inicial de AF com os incremento de salinidade inicial do solo pode ser justificado pelo aumento da quantidade de nutrientes aplicados ao solo.

As reduções da AF e da fotossíntese, provavelmente decorrente da diminuição do volume de células, contribuem de certo modo para a adaptação da cultura à salinidade (Läuchli \& Epstein, 1990; Araújo, 1994; Souza, 1995). Este fato se deve ao aumento da concentração total de solutos, o que contribui para o ajustamento osmótico, a menos que os solutos se elevem a níveis altos em compartimentos celulares específicos da folha.

A redução da AF sob estresse hídrico pode ser um mecanismo de sobrevivência que permite a conservação de água. Contudo, não necessariamente é o caso do estresse salino, onde a disponibilidade de água para o crescimento, em geral, não é limitante, à medida que o gradiente de potencial hídrico favorece a absorção, em virtude da osmorregulação. Desta forma, a redução na AF, como conseqüência do estresse salino, pode representar a inabilidade das plantas para discriminar entre os estresses hídrico e salino (Binzel et al., 1985) ao invés de um mecanismo de adaptação (Greenway \& Munns, 1980). 
As adaptações morfológicas mais comum nas plantas em condições de estresse hídrico e salino são a redução do tamanho e do número de folhas, que representam formas de reduzir a perda de água por transpiração (Maas \& Nieman, 1978; Shannon, 1979; Fageria, 1989).

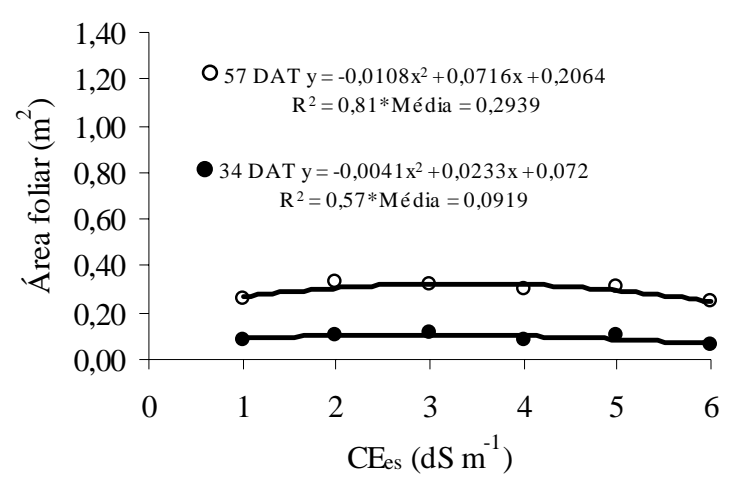

(A)

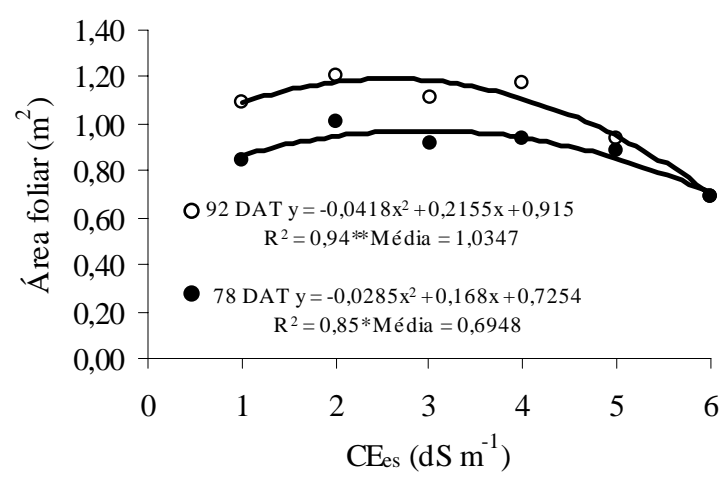

(B)

Figura 33 - Diagrama de dispersão e equação de ajuste entre a área foliar e os níveis de salinidade inicial do solo para o primeiro ciclo do meloeiro aos 34 e 57 DAT (A) e aos 78 e 92 DAT (B)

\section{Acúmulo de fitomassa}

Verifica-se, com base na análise da variância (Tabela 8), que não houve efeito da salinidade inicial do solo e do manejo da fertirrigação sobre o acúmulo de fitomassa medida no final do primeiro ciclo. Estes resultados discordam dos encontrados por Duarte (2002), que trabalhou com melão irrigado por diferentes níveis de salinidade de água em Mossoró, e demonstrou que os menores acúmulos de fitomassa foram obtidos com os maiores níveis de salinidade.

Uma das explicações mais aceitas para a inibição do crescimento devido à salinidade do solo é o desvio de energia do crescimento para a adaptação ao estresse, isto é, a redução na matéria seca pode refletir o custo metabólico de energia, associado à adaptação a salinidade e redução no ganho de carbono (Richardson \& McCree, 1985). Aí, pode-se incluir a regulação do transporte e distribuição iônica em vários órgãos e 
dentro das células, a síntese de solutos orgânicos para a osmorregulação e/ou proteção de macromoléculas, e a manutenção da integridade das membranas. Assim, a menor redução no crescimento do genótipo tolerante pode estar associada, entre outros fatores, a um menor custo de energia para a osmorregulação, o qual pode ser conseguido por meios da acumulação e da compartimentação de solutos inorgânicos no vacúolo e solutos orgânicos no citoplasma (Tal, 1985).

Tabela 8. Resumo da análise de variância para acúmulo de fitomassa medido no final do primeiro ciclo do meloeiro, em função dos níveis de salinidade e manejo da fertirrigação

\begin{tabular}{lc}
\hline \multicolumn{1}{c}{ Fator de variação } & Variável \\
\cline { 2 - 2 } & Área foliar (AF) \\
\hline - Salinidade (S) & $1,69^{\mathrm{ns}}$ \\
Linear & $0,879^{\mathrm{ns}}$ \\
Quadrático & $3,79^{\mathrm{ns}}$ \\
- Manejo (M) & $0,19^{\mathrm{ns}}$ \\
S x M & $0,562^{\mathrm{ns}}$ \\
CV (\%) & 17,17 \\
\hline
\end{tabular}

ns Não significativo ao nível de 0,05 de probabilidade pelo teste $\mathrm{F}$.

* Significativo ao nível de 0,05 de probabilidade pelo teste F.

**Significativo ao nível de 0,01 de probabilidade pelo teste $\mathrm{F}$.

\subsubsection{Produção e componentes da produção}

Na Tabela 9 encontra-se o resumo da análise de variância e as médias para a variável produção e componentes da produção para os dois ciclos consecutivos do meloeiro. No primeiro ciclo, verifica-se que houve efeito linear significativo $(p<0,01)$ dos níveis iniciais de salinidade do solo sobre rendimentos total (RT) e comercial (RC), e ainda, sobre o peso médio de fruto total (PMT); porém a salinidade não interferiu significativamente sobre o peso médio de fruto comercial (PMC). Já no segundo ciclo, não houve efeito significativo da salinidade na produção e nos componentes da produção. Para o fator manejo da fertirrigação, em ambos os ciclos, houve efeito significativo $(\mathrm{p}<0,05)$ apenas para o PMT. 
O máximo rendimento total e comercial obtido foi, respectivamente, igual a 987 e $490 \mathrm{~g} \mathrm{planta}^{-1}$ para o primeiro ciclo e 1031 e $1030 \mathrm{~g}$ planta $^{-1}$ para o segundo ciclo, respectivamente (Tabela 9). Considerando-se uma densidade populacional de 30.303 plantas por hectare, pode-se quantificar um rendimento médio comercial de aproximadamente de 14,86 e $31,24 \mathrm{Mg} \mathrm{ha}^{-1}$ para o primeiro e segundo ciclo, respectivamente.

Em ambos os ciclos, os rendimentos obtidos foram inferiores aos verificados por Cardoso (2002) que alcançou produtividade comercial média de 57,21 Mg ha-1, utilizando o mesmo híbrido de melão, cultivado em ambiente protegido em Piracicaba. Acredita-se que o baixo rendimento da cultura no primeiro ciclo deveu-se às condições climáticas que, em geral, foram consideradas impróprias para o cultivo do melão (temperatura e radiação baixas). Pinto (1997), trabalhando com o melão valenciano Amarelo em ambiente protegido e em campo, obteve rendimentos de aproximadamente 28,7 $\mathrm{Mg} \mathrm{ha}^{-1}$ e 38,6 $\mathrm{Mg} \mathrm{ha}^{-1}$, respectivamente, e sugeriu que a menor produção em ambiente protegido estava associada com ocorrência de frentes frias durante os períodos de florescimento e frutificação.

Já no segundo ciclo, embora as condições climáticas registradas tenham sido favoráveis ao cultivo, as altas infestações de nematóides e o reduzido número de frutos por planta limitaram o rendimento da cultura. Deve-se ressaltar que o reduzido número de flores hermafroditas, possivelmente associado com a ineficiência da polinização artificial resultou, em algumas plantas, em um número menor de frutos do que o estabelecido após o raleamento, fato este que não ocorreu no primeiro ciclo. Em termos de tolerância relativa da cultura, pode-se verificar uma perda de rendimento relativo na produção total por aumento unitário de $\mathrm{CE}_{\mathrm{es}}$ (b) de 7,4 e 5,9\% por dS m m $^{-1}$ para o primeiro e segundo ciclo, respectivamente (Tabela 9). Deve-se ressaltar, que a salinização do solo foi induzida pela aplicação excesso de fertilizantes, principalmente a base de cálcio e potássio. 
Tabela 9. Resumo da análise de variância e médias do rendimento total (RT), rendimento comercial (RC), peso médio de fruto total (PMFT) e peso médio de fruto comercial (PMFC) para os dois ciclos consecutivos do meloeiro, em função dos níveis de salinidade e dos manejos da fertirrigação

\begin{tabular}{|c|c|c|c|c|c|c|c|c|}
\hline \multirow{3}{*}{ Fator } & \multicolumn{8}{|c|}{ Estatística F } \\
\hline & \multicolumn{4}{|c|}{ Ciclo 1} & \multicolumn{4}{|c|}{ Ciclo 2} \\
\hline & RT & RC & PMT & PMC & RT & RC & PMT & PMC \\
\hline - Salinidade (S) & $5,59 * *$ & $3,52 *$ & $2,17^{\mathrm{ns}}$ & $0,91^{\mathrm{ns}}$ & $0,98^{\text {ns }}$ & $1,12^{\mathrm{ns}}$ & $1,37^{\mathrm{ns}}$ & $1,06^{\mathrm{ns}}$ \\
\hline Linear & $26,41 * *$ & $15,25^{* *}$ & $8,20 * *$ & $3,50^{\mathrm{ns}}$ & $0,91^{\mathrm{ns}}$ & $1,71^{\mathrm{ns}}$ & $1,75^{\mathrm{ns}}$ & $0,41^{\mathrm{ns}}$ \\
\hline Quadrático & $0,168^{\mathrm{ns}}$ & $0,001^{\mathrm{ns}}$ & $0,74^{\mathrm{ns}}$ & $0,028^{\text {ns }}$ & $1,65^{\mathrm{ns}}$ & $1,73^{\mathrm{ns}}$ & $3,16^{\mathrm{ns}}$ & $2,62^{\mathrm{ns}}$ \\
\hline - Manejo (M) & $1,26^{\mathrm{ns}}$ & $0,92^{\text {ns }}$ & $0,008^{\mathrm{ns}}$ & $1,08^{\mathrm{ns}}$ & $2,05^{\mathrm{ns}}$ & $2,05^{\mathrm{ns}}$ & $4,89 *$ & $2,18^{\mathrm{ns}}$ \\
\hline $\mathbf{S} \times \mathbf{M}$ & $1,57^{\mathrm{ns}}$ & $0,44^{\mathrm{ns}}$ & $0,29^{\mathrm{ns}}$ & $0,18^{\mathrm{ns}}$ & $1,49^{\mathrm{ns}}$ & $1,14^{\mathrm{ns}}$ & $0,49^{\mathrm{ns}}$ & $0,44^{\mathrm{ns}}$ \\
\hline \multirow[t]{2}{*}{ CV (\%) } & 19,52 & 53,86 & 12,11 & 40,78 & 39,41 & 53,61 & 27,95 & 40,56 \\
\hline & \multicolumn{2}{|c|}{ g planta $^{-1}$} & \multicolumn{2}{|c|}{ g fruto ${ }^{-1}$} & \multicolumn{2}{|c|}{ g planta $^{-1}$} & \multicolumn{2}{|c|}{ g fruto ${ }^{-1}$} \\
\hline \multicolumn{9}{|l|}{ Salinidade (S) } \\
\hline $\mathrm{S}_{1}=1$ & 987 & 490 & 512 & 621 & 1031 & 1030 & 860 & 860 \\
\hline$S_{2}=2$ & 950 & 443 & 513 & 613 & 729 & 632 & 732 & 673 \\
\hline $\mathrm{S}_{3}=3$ & 856 & 300 & 482 & 546 & 827 & 784 & 734 & 691 \\
\hline $\mathrm{S}_{4}=4$ & 773 & 376 & 506 & 550 & 724 & 631 & 593 & 546 \\
\hline$S_{5}=5$ & 776 & 233 & 459 & 426 & 857 & 707 & 730 & 772 \\
\hline$S_{6}=6$ & 618 & 181 & 440 & 488 & 796 & 709 & 729 & 721 \\
\hline $\mathrm{S}_{6} / \mathrm{S}_{1}$ & 0,63 & 0,37 & 0,86 & 0,79 & 0,77 & 0,69 & 0,85 & 0,84 \\
\hline \multicolumn{9}{|l|}{ Manejo (M) } \\
\hline$\dot{\mathrm{M}}_{1}$ & $800 a$ & $312 \mathrm{a}$ & $486 a$ & $507 a$ & $760 a$ & $644 a$ & $664 b$ & 649a \\
\hline $\mathrm{M}_{2}$ & 853a & $362 \mathrm{a}$ & $485 a$ & $574 a$ & $895 a$ & $855 a$ & $795 a$ & $772 \mathrm{a}$ \\
\hline Média & 827 & 337 & 485 & 540 & 828 & 750 & 730 & 710 \\
\hline
\end{tabular}

Conforme citado anteriormente, o meloeiro apresenta uma grande variação no nível de tolerância à salinidade entre os cultivares, comprovando a afirmação de Ayres Westcot (1991) de que a tolerância das culturas varia tanto entre espécies como para cultivares da mesma espécie. Amor et al. (1999), estudando os efeitos da aplicação de água salina em diferentes tempos de exposição sob o cultivo de melão rendilhado (cv. Gália), encontrou uma perda de rendimento relativa por aumento unitário de $\mathrm{CE}_{\text {es }}$ de 9,6 $\%$ por dS $\mathrm{m}^{-1}$ para a solução salina aplicada a partir dos 14 DAT. Entretanto, neste experimento, o substrato foi salinizado com solução nutritiva salina a base de $\mathrm{NaCl}$. Neste caso, a maior perda de rendimento relativo por aumento unitário de CE 
encontrado pode estar associada aos tipos de sais, pois o sódio quando acumulado no solo é mais prejudicial que o potássio, conforme relatado por Silva (2002). Desse modo, a tolerância da cultura do melão à salinidade, no que se refere a perda de rendimento total relativo por aumento unitário da $\mathrm{CE}_{\mathrm{es}}$, foi inferior ao encontrado na literatura, possivelmente devido aos tipos de sais presentes.

As análises de regressão apresentadas na Figuras 34 para o primeiro ciclo seguem um ajuste linear decrescente para o rendimento total e comercial dos frutos, peso médio dos frutos total e comercial, com redução relativa entre $S_{1}$ e $S_{6}$ de 34,98, 61,30, 13,66 e $27,76 \%$, respectivamente. Maas \& Hoffman (1977) mostraram que as altas concentrações de sais diminuem o potencial osmótico na solução do solo, reduzindo a disponibilidade de água das plantas, sendo que as culturas mais sensíveis sofrem redução progressiva na produção e componentes de produção à medida que a concentração salina aumenta.

De acordo com Medeiros (1998), a redução no rendimento total dos frutos com o aumento da salinidade é avaliada pelo efeito dos tratamentos nos componentes de produção e no índice de falha do stand. No presente trabalho não foram observadas falhas no stand populacional dos tratamentos de níveis mais salinos e, portanto, a redução do rendimento de frutos deveu-se principalmente à diminuição do peso médio dos mesmos. Estes resultados corroboram com os encontrados por Mendlinger (1994), Nukaya et al., (1980) e Shannon \& Francois (1978), que estudando a tolerância do melão à salinidade, demonstraram que a salinidade diminui o rendimento principalmente devido a redução do peso médio do fruto. 


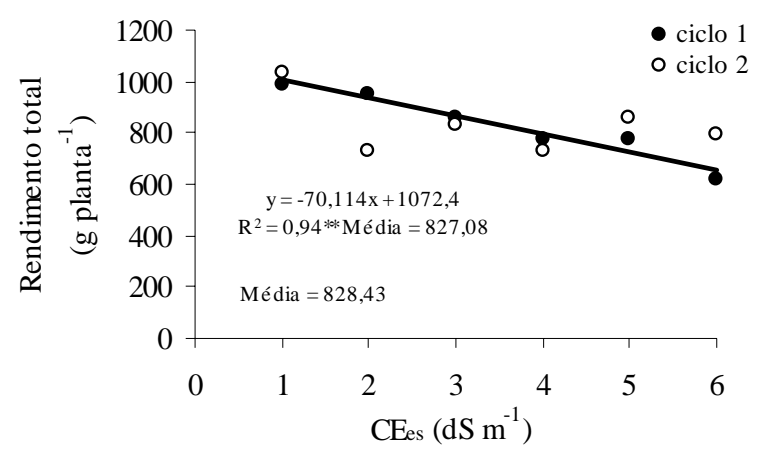

(A)

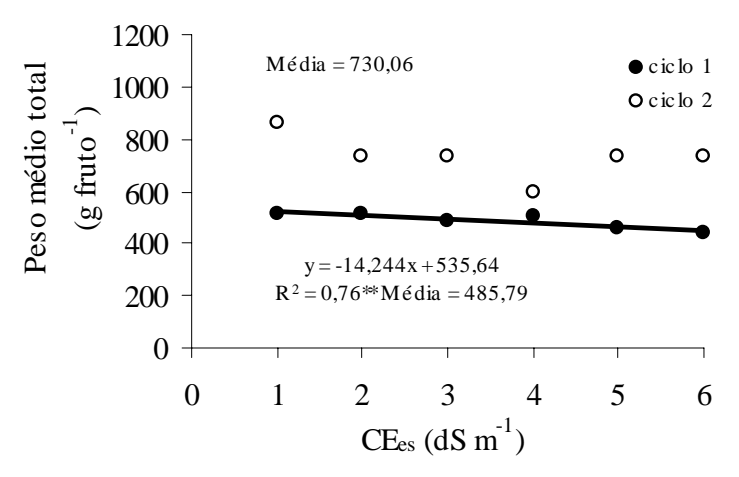

(C)

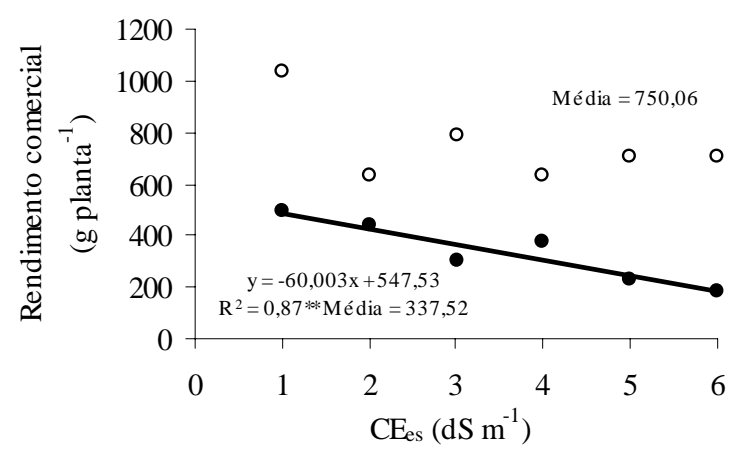

(B)

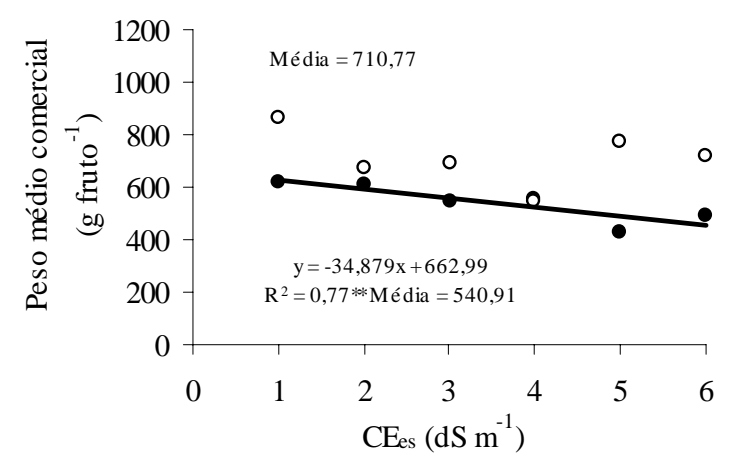

(D)

Figura 34 - Diagrama de dispersão e equação de ajuste entre o rendimento total (A), rendimento comercial (B), peso médio de frutos total (C) e peso médio de fruto comercial (D), para os dois ciclos, em função dos níveis de salinidade inicial do solo 


\subsubsection{Qualidade pós-colheita de frutos de meloeiro}

\section{Qualidade química}

No primeiro ciclo, os níveis de salinidade do solo e o manejo da fertirrigação não afetaram significativamente $(\mathrm{p}>0,05)$ a qualidade química dos frutos no que se refere aos conteúdos médios de sólidos solúveis totais (SST), pH e acidez total titulável (ATT). Porém, no segundo ciclo, constatou-se efeito linear significativo da salinidade $(\mathrm{p}<0,05$ e 0,01) para o SST e pH. Observou-se no primeiro e no segundo ciclo valores médios de 11,10 e $8,07 \%$ para SST, 5,80 e 5,67 para $\mathrm{pH}$ e 22,87 e 15,30 \% para ATT, respectivamente (Tabela 10).

Muitos países adotam os valores do conteúdo de sólidos solúveis totais como uma referência de mercado para aceitabilidade, com variação mínima de 8 a $10{ }^{\circ}$ Brix; entretanto, se este caráter for analisado isoladamente como atributo de qualidade, poderá ser falho (Menezes, 1996). Aulenbach \& Worthington (1974) indicam que o SST não é sempre um bom indicador de qualidade, principalmente quando o mesmo é superior a $8 \%$, e que outros indicadores de qualidade tais como firmeza, cor e compostos voláteis podem ser utilizados como fatores complementares.

De acordo com os dados apresentados na Tabela 10, nenhum dos valores médios obtidos no primeiro ciclo estão abaixo do mínimo exigido pelo mercado, sendo semelhantes aos teores de sólidos solúveis produzidos nos melões do Brasil, aproximando-se dos valores encontrados por Prabhakar et al. (1985). Já no segundo ciclo, os níveis de salinidade alteraram o teor de sólidos totais.

Segundo Hubbard et al. (1990), fatores nutricionais como deficiência de potássio, reduzem drasticamente a fotossíntese e, conseqüentemente, o acúmulo de sacarose no fruto, resultando em melões de baixa qualidade. Para Bleinroth (1994), baixos valores

dos SST podem estar associados ao efeito de padronização de épocas de colheita de frutos sem completo desenvolvimento do tecido de abscisão e à não ocorrência do completo desprendimento do fruto do pedúnculo. 
Tabela 10. Resumo da análise de variância e médias do teor de sólido solúvel total (SST), pH e acidez total titulável (ATT) em frutos de meloeiro, para os dois ciclos consecutivos, em função dos níveis de salinidade e manejo da fertirrigação

\begin{tabular}{|c|c|c|c|c|c|c|}
\hline \multirow{3}{*}{ Fator } & \multicolumn{6}{|c|}{ Estatística F } \\
\hline & \multicolumn{3}{|c|}{ Ciclo 1} & \multicolumn{3}{|c|}{ Ciclo 2} \\
\hline & SST & $\mathrm{pH}$ & ATT & SST & $\mathrm{PH}$ & $\mathrm{ATT}$ \\
\hline - Salinidade (S) & $0,56^{\mathrm{ns}}$ & $1,59^{\mathrm{ns}}$ & $0,94^{\mathrm{ns}}$ & $2,18^{\mathrm{ns}}$ & $2,64^{\mathrm{ns}}$ & $3,61 *$ \\
\hline Linear & $0,248^{\mathrm{ns}}$ & $3,73^{\mathrm{ns}}$ & $1,33^{\mathrm{ns}}$ & $7,84^{*}$ & $11,11^{* *}$ & $2,54^{\mathrm{ns}}$ \\
\hline Quadrático & $0,402^{\mathrm{ns}}$ & $2,50^{\mathrm{ns}}$ & $1,12^{\mathrm{ns}}$ & $0,0001^{\mathrm{ns}}$ & $0,02^{\mathrm{ns}}$ & $0,64^{\mathrm{ns}}$ \\
\hline - Manejo (M) & $1,55^{\mathrm{ns}}$ & $2,42^{\mathrm{ns}}$ & $0,74^{\mathrm{ns}}$ & $1,34^{\mathrm{ns}}$ & $1,64^{\mathrm{ns}}$ & $0,008^{\mathrm{ns}}$ \\
\hline $\mathbf{S} \times \mathbf{M}$ & $0,842^{\mathrm{ns}}$ & $0,21^{\mathrm{ns}}$ & $0,76^{\mathrm{ns}}$ & $0,49^{\mathrm{ns}}$ & $0,16^{\mathrm{ns}}$ & $1,92^{\mathrm{ns}}$ \\
\hline \multirow[t]{3}{*}{ CV (\%) } & 10,85 & 2,90 & 8,98 & 20,72 & 5,38 & 8,73 \\
\hline & \multicolumn{6}{|c|}{ Médias } \\
\hline & $\%$ & & $\mathrm{mg} \mathrm{kg}^{-1}$ & $\%$ & & $\mathrm{mg} \mathrm{kg}^{-1}$ \\
\hline \multicolumn{7}{|l|}{ Salinidade (S) } \\
\hline $\mathrm{S}_{1}=1 \mathrm{dS} \mathrm{m}^{-1}$ & 10,81 & 5,69 & 21,49 & 9,25 & 5,96 & 14,50 \\
\hline $\mathrm{S}_{2}=2 \mathrm{dS} \mathrm{m}^{-1}$ & 11,06 & 5,79 & 23,17 & 8,80 & 5,79 & 16,12 \\
\hline $\mathrm{S}_{3}=3 \mathrm{dS} \mathrm{m}^{-1}$ & 11,09 & 5,77 & 22,89 & 7,82 & 5,64 & 14,17 \\
\hline $\mathrm{S}_{4}=4 \mathrm{dS} \mathrm{m} \mathrm{m}^{-1}$ & 11,63 & 5,90 & 23,35 & 8,72 & 5,76 & 16,01 \\
\hline $\mathrm{S}_{5}=5 \mathrm{dS} \mathrm{m}^{-1}$ & 10,76 & 5,89 & 22,45 & 6,75 & 5,46 & 14,48 \\
\hline $\mathrm{S}_{6}=6 \mathrm{dS} \mathrm{m}^{-1}$ & 11,23 & 5,80 & 23,22 & 7,10 & 5,44 & 16,57 \\
\hline \multicolumn{7}{|l|}{ Manejo (M) } \\
\hline $\mathrm{M}_{1}$ & $11,32 \mathrm{a}$ & 5,84 a & 23,17 a & $7,75 \mathrm{a}$ & $5,61 \mathrm{a}$ & 15,29 a \\
\hline $\mathrm{M}_{2}$ & $10,88 \mathrm{a}$ & 5,77 a & $22,50 \mathrm{a}$ & 8,39 a & $5,74 \mathrm{a}$ & 15,32 a \\
\hline Média & 11,10 & 5,80 & 22,83 & 8,07 & 5,67 & 15,30 \\
\hline
\end{tabular}

Welles \& Buitelaar (1988) verificaram que o conteúdo de sólidos solúveis diminui significativamente com a diminuição da área foliar, isto é, quanto maior a área foliar de plantas, maior também sua capacidade fotossintética. Isto, provavelmente, explica o decréscimo linear do SST dos frutos com o aumento dos níveis de salinidade do solo, observado no segundo ciclo (Figura 35).

Barros (2002), estudando três níveis de salinidade de água de irrigação em campo, observou um efeito linear positivo sobre o SST dos frutos do meloeiro devido ao incremento da salinidade. De modo contrário, Costa (1999) concluiu que a tendência foi a de diminuir de 11,4 para 10,8 \% o conteúdo de SST ao se aumentar à salinidade da 
água de irrigação, ou seja, o estresse osmótico reduziu o conteúdo de sólidos solúveis dos frutos de meloeiro.

Com relação ao pH do fruto, no segundo ciclo, o efeito da salinidade do solo pode ser representado por meio de uma equação de primeiro grau, em que se verifica um decréscimo relativo entre $\mathrm{S}_{1}$ e $\mathrm{S}_{6}$ de $8,37 \%$, com ajuste significativo $(\mathrm{P}<0,01)$ e coeficiente de determinação $\mathrm{R}^{2}=0,84$ (Figura 35).

Amor et al. (1999) verificou que a qualidade de frutos de meloeiro foi significativamente afetada pelos níveis de salinidade, sendo que a ATT e o ${ }^{\circ}$ Brix aumentaram, enquanto que o $\mathrm{pH}$ diminui com o aumento da salinidade.

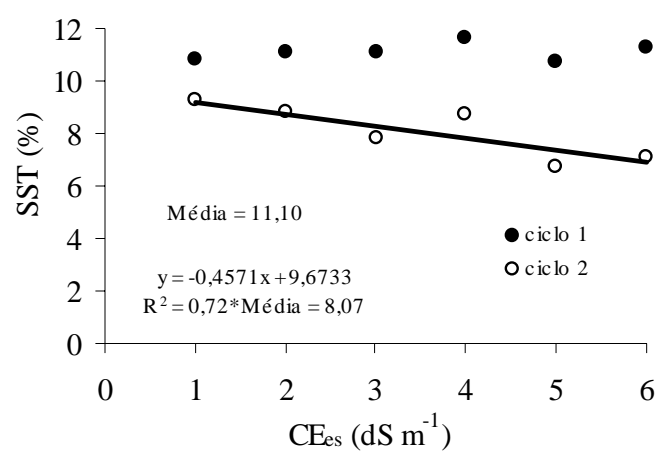

(A)

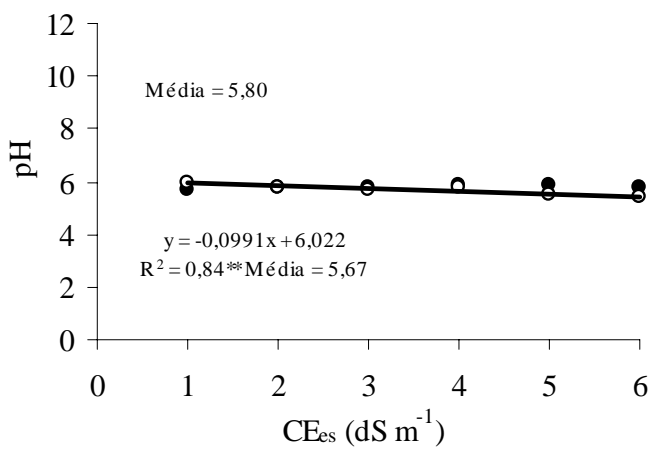

(B)

Figura 35 - Diagrama de dispersão e equação de ajuste entre o conteúdo de sólidos solúveis totais (A) e pH (B) para os dois ciclos, em função dos níveis de salinidade inicial do solo

\section{Qualidade física}

Na Tabela 11 estão apresentadas as médias da firmeza de polpa (FP-textura), da espessura da casca (EC) e da espessura da polpa (EP) dos frutos de meloeiro, em função dos diferentes níveis de salinidade e dos manejos da fertirrigação para o segundo ciclo do meloeiro.

Não se constatou efeito significativo de nenhum dos fatores estudados sobre estas variáveis. Estes resultados corroboram com a observação de Barros (2002) para a 
firmeza de polpa, e se contrapõem aos resultados encontrados por Amor et al. (1999), que estudando os diferentes níveis de salinidade na solução de irrigação, verificou que a espessura e a firmeza de polpa foi significativamente reduzida por incrementos dos níveis de salinidade.

Os valores de textura obtidos variaram de 19,93 a 17,45 N, estando próximos aos encontrados por Santos (2002) com o híbrido Orange Flesh (15,66 N) e por Vásquez (2003) com híbrido Bônus 2 (17,5 N) e inferiores aos encontrados por Granjeiro et al. (1999), que verificou em melão do tipo amarelo, na época da colheita, valores de textura de 28,51 a 40,50 N. Os baixos valores de FP encontrados estão associados à característica da variedade estudada (melão rendilhado), que apresenta baixa vida útil pós-colheita e menor resistência ao transporte, se comparada ao melão amarelo (Sousa et al., 1999).

Dinus \& Mackey (1974) afirmam que a textura do melão tipo cantaloupe é determinada principalmente pelo tipo e qualidade dos constituintes da parede celular, destacando-se o conteúdo de pectina solúvel e as estruturas das hemiceluloses. Essa característica é um dos recursos mais utilizados no acompanhamento do amolecimento dos frutos, uma vez que sofre alterações durante este processo.

A firmeza da polpa, apesar de ser um parâmetro físico, está relacionada com a solubilização de substâncias pécticas, as quais, segundo Chitarra \& Chitarra (1990), quando em grande quantidade, conferem textura frágil aos frutos. Melões considerados com boa capacidade de conservação, como os do tipo Amarelo, apresentam valores elevados para FP. Essa característica parece sofrer grande influência ambiental, com valores muito variáveis, mesmo no melão Amarelo. No híbrido "Gold Mine" já foram citados valores de 21,22 N (Granjeiro et al. 1999), 29,62 N (Dias, 1998) e até de 37,1 N (Sena et al., 2000). Por outro lado, nos melões Cantaloupe a FP se situa ao redor de 23,6 N (Vale, 2000). Especificamente, no híbrido "Hy Mark", existem citações de 20,35 N (Santos, 2002), e de 30,17 a 34,20 N (Almeida, 2001).

Sob o ponto de vista de manuseio pós-colheita, a firmeza é essencial em razão do fato dos frutos com maior firmeza serem mais resistentes às injurias mecânicas que ocorrem durante o transporte e comercialização. É também um atributo de qualidade 
importante, pois a liberação de compostos presentes nos produtos, que são perceptíveis pelo paladar, são também relacionados com a estrutura do tecido (Chitarra \& Chitarra, 1990).

Tabela 11. Resumo da análise de variância e médias da firmeza de polpa, espessura da casca e espessura da polpa em frutos de meloeiro, para o segundo ciclo, em função dos níveis de salinidade e do manejo da fertirrigação

\begin{tabular}{|c|c|c|c|}
\hline \multirow[t]{2}{*}{ Fator } & \multicolumn{3}{|c|}{ Estatística F } \\
\hline & Textura & Espessura da casca & Espessura da polpa \\
\hline - Salinidade (S) & $0,49^{\text {ns }}$ & $0,98^{\mathrm{ns}}$ & $0,54^{\mathrm{ns}}$ \\
\hline Linear & $0,075^{\mathrm{ns}}$ & $3,99^{\text {ns }}$ & $0,60^{\mathrm{ns}}$ \\
\hline Quadrático & $2,14^{\mathrm{ns}}$ & 0,061 & $0,08^{\mathrm{ns}}$ \\
\hline - Manejo (M) & $0,04^{\mathrm{ns}}$ & $0,08^{\mathrm{ns}}$ & $1,40^{\mathrm{ns}}$ \\
\hline S $\times M$ & $0,927^{\mathrm{ns}}$ & $0,254^{\mathrm{ns}}$ & $0,93^{\mathrm{ns}}$ \\
\hline \multirow[t]{3}{*}{ CV (\%) } & 24,75 & 21,90 & 13,98 \\
\hline & & Médias $^{\#}$ & \\
\hline & $\mathbf{N}$ & \multicolumn{2}{|c|}{$\mathbf{m m}$} \\
\hline \multicolumn{4}{|l|}{ Salinidade (S) } \\
\hline$S_{1}=1$ & 16,42 & 1,13 & 30,45 \\
\hline$S_{2}=2$ & 18,50 & 1,06 & 27,96 \\
\hline $\mathrm{S}_{3}=3$ & 19,47 & 1,08 & 31,30 \\
\hline $\mathrm{S}_{4}=4$ & 19,93 & 0,99 & 30,53 \\
\hline$S_{5}=5$ & 18,03 & 0,89 & 30,16 \\
\hline$S_{6}=6$ & 17,45 & 0,95 & 31,53 \\
\hline \multicolumn{4}{|l|}{ Manejo (M) } \\
\hline $\mathrm{M}_{1}$ & $18,15 a$ & $1,01 \mathrm{a}$ & $29,49^{\mathrm{a}}$ \\
\hline $\mathrm{M}_{2}$ & $18,45 a$ & 1,03a & $31,16^{\mathrm{a}}$ \\
\hline Média & 18,30 & 1,02 & 30,32 \\
\hline
\end{tabular}

\subsubsection{Considerações finais e recomendações}

A tolerância das plantas à salinidade depende de diversos fatores, incluindo o estágio de crescimento, o tempo e a duração da exposição da planta ao sais no solo, as condições ambientais e o tipo de substrato (Adams, 1991; Kuehny \& Morales, 1998; Maas \& Hoffman, 1977). Amor et al. (1999), estudando diferentes níveis de salinidade na água de irrigação, aplicados em diferentes épocas após o transplantio do melão, 
observou efeitos mais severos quando os sais foram aplicados no início do crescimento vegetativo, tendo menor efeito quando aplicado na fase final do ciclo.

É importante ressaltar que no início do experimento a salinidade do solo não variou com o manejo da fertirrigação e, mesmo após o início da correção do manejo controlado, os níveis de salinidade do manejo tradicional se mantiveram próximos aos seus valores iniciais até aproximadamente 69 DAT (Figura 13) e, portanto, próximos aos tratamentos do manejo controlado. Considerando que a resposta das plantas à salinidade não depende apenas da concentração de sais, mas também da duração do tempo de exposição, o efeito não significativo entre os dois manejos da fertirrigação estudados, tanto no rendimento como nas variáveis de crescimento estaria explicado. Isto por que a diferença da salinidade do solo entre os manejos começou a ser notória somente a partir do início da frutificação (69 DAT). Amor et al. (1999) encontrou redução na produção comercial relativa de frutos de melão de plantas expostas a $8 \mathrm{dS} \mathrm{m} \mathrm{m}^{-1}$, na faixa de $56 \%$ quando a salinização foi iniciada aos 14 DAT e 16 \% quando os sais foram aplicados a partir dos 71 DAT.

Pode-se deduzir que o ciclo relativamente curto do meloeiro (117 dias), não foi suficiente para propiciar respostas significativas entre os manejos da fertirrigação, devido ao reduzido tempo de exposição das plantas aos sais. Silva (2002), estudando os efeitos de diferentes níveis de salinidade sobre a cultura do pimentão, em associação com manejo tradicional e controlado da fertirrigação, observou que em solo francoarenoso houve diferenças significativas entre os dois manejos somente nas medidas de altura e diâmetro de colo realizadas aos 150 DAT e para a biomassa de raiz, caule e planta somente no final do ciclo.

Por outro lado, como no manejo $\mathrm{M}_{2} \mathrm{o}$ controle foi realizado apenas na concentração total de sais na solução $\left(\mathrm{CE}_{\mathrm{es}}\right)$ e não na concentração de íons específicos, como o $\mathrm{NO}^{-3}$ e o $\mathrm{K}^{+}$, é possível que tenha havido limitação no crescimento das plantas no manejo $\mathrm{M}_{2}$ em razão da deficiência nutricional, principalmente nos níveis mais baixos de salinidade.

A cultura do melão é muito exigente em temperatura, não se recomendando o seu cultivo em épocas de baixas temperaturas na região de Piracicaba, mesmo em condições 
protegidas. Soares (2001), trabalhando com melão rendilhado em condições protegidas no período 20 de abril a 28 de junho de 2001, também verificou uma redução acentuada na produtividade comercial dos frutos, ocasionada provavelmente devido às baixas temperaturas ocorridas no período.

Deve-se finalmente ressaltar a importância da rotação de culturas, pois o ataque severo de nematóides, que prejudicou a avaliação dos efeitos dos fatores experimentais no segundo ciclo deve ter sido favorecido pelo cultivo sucessivo da mesma espécie vegetal. 


\section{CONCLUSÕES}

Considerando as condições em que os experimentos foram desenvolvidos, os resultados obtidos permitiram concluir que:

- A técnica utilizada para salinizar artificialmente o solo, com aplicação excessiva de fertilizantes, permite que se atinjam os valores de $\mathrm{CE}_{\mathrm{es}}$ desejados com boa precisão.

- É possível, com auxílio dos extratores de solução por cápsulas porosas, monitorar a concentração total de íons na solução do solo e manter a salinidade em nível desejado, controlando a condutividade elétrica da solução extraída.

- Os níveis iniciais de salinidade do solo provocados pela aplicação excessiva de adubos afetaram significativamente o crescimento do meloeiro, a produção e os seus componentes.

- Não foi possível se detectar diferenças expressivas no crescimento ou na produção do meloeiro que pudessem ser atribuídas aos dois tipos de manejo da fertirrigação utilizados.

- Nenhuma variável relativa ao crescimento ou à produção da cultura confirma a possibilidade do meloeiro resistir mais à salinidade proporcionada por excesso de adubos do que aos sais usualmente presentes nas águas de irrigação de qualidade marginal.

- Os efeitos da salinidade do solo sobre a altura e o diâmetro das plantas foram mais severos durante o desenvolvimento vegetativo inicial do que no início da formação dos frutos, o que sugere uma possível adaptação das plantas ao estresse salino ao longo do tempo. 


\section{REFERÊNCIAS BIBLIOGRÁFICAS}

ADAMS, P. Effects of increasing the salinity of the nutrient solution with major nutrients or sodium chloride on the yield, quality and composition of tomatoes grown in rockwool. Journal of Horticultural Science, v. 66, n5. p.201-207, 1991.

ALMEIDA, A.V. Atividade respiratória e produção de etileno em diferentes híbridos de melão cultivados no pólo agrícola Mossoró-Açú (compact disc). Horticultura Brasileira, v. 19, supl., 2001.

AMOR, F.M. del; MARTINEZ, V.; CERDÁ, A. Salinity duration and concentration affect fruit yield and quality, and growth and mineral composition of melon plants in perlite. HortScience, v.34, n.7, p.1234-1237, 1999.

ANDRIOLO, J.L. Fisiologia das culturas protegidas. Santa Maria: UFSM, 1999. 142p.

ARAÚJO, C.A.S. Avaliação de feijoeiro quanto a tolerância à salinidade em solução nutritiva. Viçosa, 1994. 87 p. Dissertação (Mestrado) - Universidade Federal de Viçosa.

AULENBACH, B.B.; WORTHINGTON, J.T. Sensory evaluation of muskmelons: is soluble solids content a good quality index. HortScience, v.9, p.136-137, 1974.

AYERS, R.S.; WESTCOT, D. W. Qualidade de água na agricultura. Trad. de H.R. Gheyi et al. Campina Grande: UFPB, 1991. 218p. (FAO. Estudos de Irrigação e Drenagem, 29). 
BARROS, A.D. de. Manejo da irrigação por gotejamento com diferentes níveis de salinidade da água na cultura do melão. Botucatu, 2002. 107 p. Tese (Doutorado) Faculdade de Ciências Agronômicas, Universidade Estadual Paulista "Júlio de Mesquita Filho”.

BERNSTEIN, L. Effect of salinity and sodicity on plant growth. Plant Analysis and Fertilizer Problems, v.4, p.25-45, 1964.

BERNSTEIN, L.; PEARSON, G.A. Influence of integrated moisture stress achieved by varying the osmotic pressure of culture solutions on growth of tomato and pepper plants. Soil Science, v.77, p.355-368, 1954.

BINZEL, M.L.; HASEGAWA, P.M.; HANDA, A.K.; BRESSAN, R.A. Adaptation of tobacco cells to NaCl. Plant Physiology, v.79, p.118-125, 1985.

BLANCO, F.F. Tolerância do pepino enxertado à salinidade em ambiente protegido e controle da salinização do solo. Piracicaba, 1999, 104 p. Dissertação (Mestrado) Escola Superior de Agricultura “Luiz de Queiroz”, Universidade de São Paulo.

BLEINROTH, E.W. Determinação do ponto de colheita. In: GONZAGA NETTO, A. Melão para exportação: procedimentos de colheita e pós-colheita. Brasília: Embrapa SPI, 1994. 37p. (Série Publicações Técnicas FRUPEX, 6).

BRANDÃO FILHO, J. U. T., CALLEGARI, O. Cultivo de hortaliças de frutos em solo em ambiente protegido. Informe Agropecuário, v.20, p.64 - 68, 1999.

BURGUEÑO, H. La fertirrigación en cultivos hortícolas com acolchado plástico. Culiacán: BURSAR, 1996. v.1, 45p.

CAMPOS, I.S.; ASSUNÇÃO, M.V. Estresse salino e hídrico na germinação e vigor de arroz. Pesquisa Agropecuária Brasileira, v.25, n.6, p.857-862, 1990. 
CARDOSO, S.S. Doses de $\mathrm{CO}_{2}$ e de potássio aplicadas através da irrigação no meloeiro rendilhado (Cucumis melon L.) cultivado em ambiente protegido. Piracicaba, 2002. 101p. Tese (Doutorado) - Escola Superior de Agricultura “Luiz de Queiroz”, Universidade de São Paulo.

CARRIJO, O.A.; MAROUELLI, W.A.; SILVA, H.R. Manejo da água na produção de hortaliças em cultivo protegido. Informe Agropecuário, v.20, n.200/201, p.45-51, 1999.

CHITARRA, A.B.; CHITARRA, M.I. Pós-colheita de frutas e hortaliças: fisiologia e manuseio. Lavras: ESAL; FAEPE, 1990. 320p.

COELHO, E.L.; FONTES, P.C.R.; FINGER, F.L.; CARDOSO, A.A. Qualidade do fruto de melão rendilhado em função de doses de nitrogênio. Bragantia, v.62, n.2, p.173178, 2003.

COSTA, C.P.; PINTO, C.A.B.P. Melhoramento de hortaliças. Piracicaba: ESALQ, 1977. 319p.

COSTA, M. da C. Efeitos de diferentes lâminas de água com dois níveis de salinidade na cultura do meloeiro. Botucatu, 1999. 115p. Tese (Doutorado) - Faculdade de Ciências Agronômicas, Universidade Estadual Paulista “Júlio de Mesquita Filho”.

D’ALBUQUERQUE JÚNIOR, B.S. Efeito da aplicação de $\mathrm{CO}_{2}$. em diferentes fases fonológicas da cultura do melão (Cucumis melon L.) em ambiente protegido. Piracicaba, 2004. 84p. Dissertação (Mestrado) - Escola Superior de Agricultura “Luiz de Queiroz”, Universidade de São Paulo.

DAKER, A. Irrigação e drenagem. a água na agricultura. 2.ed. Rio de Janeiro: Freitas Bastos, 1984. 543 p. 
DELLA VECCHIA, P.T. Recomendações importantes para o cultivo com sucesso dos melões híbrido $F_{1}$ comercializados pela Agroflora. Bragança Paulista: Sementes Agroflora, 1994. 9p.

DIAS, N.S. Avaliação de diferentes tipos e espaçamentos de gotejadores usados no cultivo de melão, semeado em faixa contínua, sob duas densidades de plantio. Mossoró, 1998. 50p. Monografia (Graduação) - Escola Superior de Agricultura de Mossoró.

DIAS, N.S. Evolução da salinidade de um solo Luvissolo cultivado com melão irrigado por gotejamento. Campina Grande, 2001. 72p. Dissertação (Mestrado) Universidade Federal da Paraíba.

DIAS, N.S.; GHEYI, H.R.; DUARTE, S.N. Prevenção, manejo e recuperação dos solos afetados por sais. Piracicaba: ESALQ, Departamento de Engenharia Rural, 2003. 118p. (Série Didática, 13).

DINUS, L. A.; MACKEY, A. C. Chemical and physical attributes of muskmelon related to texture. Journal of Texture Studies, v. 5, p. 41-50, 1974.

DOORENBOS, J.; KASSAN, A.H. Efeitos da água no rendimento das culturas. Roma: FAO, 1994. 212 p. (Estudos FAO: Irrigação e Drenagem, 33).

DOORENBOS, J.; PRUITT, W.O. Las necesidades de aguas de los cultivos. Roma: FAO, 1977. 143p. (Estúdios FAO: Riego, Drenaje, 24).

DUARTE, S.R. Alterações na nutrição mineral do meloeiro em função da salinidade da água de irrigação. Campina Grande, 2002. 90p. Dissertação (Mestrado) Universidade Federal da Paraíba.

FAGERIA, N.K. Solos tropicais e aspectos fisiológicos das culturas.Brasília: EMBRAPA, DPU, 1989. 425P. (EMBRAPA.CNPAF. Documento, 18). 
FERREIRA, P.A.; MARTINEZ, M.A. Movimento e modelagem de sais no solo. In: GHEYI, H.R.; QUEIROZ, J.E.; MEDEIROS, J.F. de (Ed.). Manejo e controle da salinidade na agricultura irrigada. Campina Grande: UFPB; SBEA, 1997. cap.6, p. 171-206.

FILGUEIRA, F.A.R. Manual de olericultura: cultura e comercialização de hortaliças. 2.ed. São Paulo: Agronômica Ceres, 1982. 357p.

FILGUEIRA, H.A.; MENEZES, J.B.; ALVES, R.E. Colheita e manuseio em póscolheita. In: ALVES, R.E. (Coord.). Melão: pós-colheita. Brasília: EMBRAPA, Comunicação para Transferência de Tecnologia, 2000. p.23-41.

FILGUEIRA, H.J.A.; SOUTO, J.S. Avaliação de quatro níveis de relação solo: água para caracterização da condutividade elétrica em solos da região de Patos, PB. In REUNIÃO BRASIILEIRA DE FERTILIDADE DO SOLO E NUTRIÇÃO DE PLANTAS, 22, Manaus, 1995. Anais. Manaus: SBCS, 1995. p.282-283.

FRIZZONE, J.A.; ZANINI, J.R.; PAES, L.A.D.; NASCIMENTO, V.M. do. Fertirrigação mineral. Ilha Solteira: UNESP, 1985. 31p. (Boletim Técnico, 2).

FURLAN, R.A. Avaliação de nebulização e abertura de cortinas na redução da temperatura do ar em ambiente protegido. Piracicaba. 2001. 146p. Tese (Doutorado) Escola Superior de Agricultura Luiz de Queiroz, Universidade de São Paulo.

GOTO, R.; GUIMARÃES, V.F.; ECHER, M.M. Aspectos fisiológicos e nutricionais no crescimento e desenvolvimento de plantas hortícolas. In: FOLEGATTI, M.V.; CASARINI, E.; BLANCO, F.F.; BRASIL, R.P.C. do; RESESNDE, R.S. (Cood.). Fertirrigação: flores, frutas e hortaliças. Guaíba: Agropecuária, 2001. v.2, p.241268. 
GRANJEIRO L.C.; PEDROSA, J.F.; BEZERRA NETO, F.; NEGREIROS, M.Z. Qualidade de híbridos de melão amarelo em diferentes densidades de plantio. Horticultura Brasileira, v. 17, n. 2, p.110-114, 1999.

GREENWAY, H.; MUNNS, R. Mechanisms of salt tolerance in nonhalophytes. Annual Review of Plant Physiology, v.31, p.149-190, 1980.

GURGEL, M.T. Evolução da salinidade do solo na cultura do melão, irrigado com diferentes lâminas de água com alta e baixa salinidade. Mossoró, 1999. 49p. Monografia (Graduação) - Escola Superior de Agricultura de Mossoró.

HAYWARD, H.E.; WADLEIGH, C. H. Plant growth on saline and alkali soils. Advances in Agronomy, v.1.p. 1-38, 1949.

HOFFMAN, G.J.; HOWELL, T.A.; SOLOMON, K.H. Management farm irrigation systems. St. Joseph: ASAE, 1992. 1040p. (ASAE Monograph, 9).

HOFFMAN, G.J. Evapotranspiration in saline soils. In: NATIONAL CONFERENCE ON ADVANCES IN EVAPOTRANSPIRATION, Chicago, 1985. Proceedings. St. Joseph: ASAE, 1985. p.35-42.

HOORN, J.W.; ALPHEN, J.G. Salt movement, leaching efficienty and leaching requirement. Agricultural and Water Management. v.4, p.409-428, 1981.

HOORN, J.W.; ALPHEN, J.G. Salinity control. In: RITZEMA, H.P. (Ed.). Drainage principles and applications. Wageningen: ILRI, 1994. p.533-600. (Publication, 16)

HUBBARD, N.L.; PHARR, D.M.; HUBER, S.C. Sucrose metabolism in ripening muskmelon fruit as affected by leaf area. Journal of the American Society for Horticultural Science, v.115, p.798-802, 1990.

INGVALSON, R.D.; RHOADES, J.D.; PAGE, A.L. Correlation of alfalfa yield with various index of salinity. Soil Science, v.122, n.3, p.145-153, 1976. 
JURINAK, J.J.; WAGENET, R.J. Fertilization and salinity. In: YARON, D. (Ed.). Salinity in irrigation and water resources. New York: Marcel Dekker, 1981. p.103-119.

KANO, C. Extrações de nutrientes pelo meloeiro rendilhado cultivado em ambiente protegido com a adição de potássio e $\mathrm{CO}_{2}$ na água de irrigação. Piracicaba, 2002. 115p. Dissertação (Mestrado) - Escola Superior de Agricultura “Luiz de Queiroz”, Universidade de São Paulo.

KHAN, A.A.; YITAYEW, M.; WARRICK, A.W. Field evaluation of water an solote distribution from a point source. Jornal of Irrigation and Drainage Engineering, v.122, n.4, p.221-227, 1996.

KUEHNY, J.S.; MORALES, B. Effects of salinity and alkalinity on pansy and impatiens in three different growing media. Journal of Plant Nutrition, v.21, n.5, p.10111023, 1998.

LÄUCHLI, A.; EPSTEIN, E. Plant responses to saline and sodic condictions. In: TANJI, K.K. (Ed.). Agricultural salinity assessment and management. New York: ASCE, 1990. cap.6, p. 113-137.

LIBARDI, P.L. Dinâmica da água no solo. 2.ed. Piracicaba: O autor, 2000. 509p.

LIMA, L.A. Efeito de sais no solo e na planta. In: GHEYI, H.R.; QUEIROZ, J.E.; MEDEIROS, J.M. (Ed.). Manejo e controle da salinidade na agricultura. Campina Grande: UFPB; SBEA, 1997. p.113-136.

MAAS, E.V. Salt tolerance of plants. Applied Agricultural Research, v.1, p.12-36, 1984.

MAAS, E.V.; HOFFMAN, G.J. Crop salt tolerance - Current Assessment. Journal of Irrigation and Drainage Division of ASCE, v.103, n IR2, p.115-134, 1977. 
MAAS, E.V.;NIEMAN, R.H. Physiology of plant tolerant to salinity. In: JUNG, G.A. (Ed.). Crop tolerance to sub-optional land conditions. Madison: American Society Agronomy. 1978. cap.1. p.277-279. (Special Publication, 32).

MARUYAMA, I.W. Condução do melão rendilhado sob cultivo protegido. Jaboticabal, 1999. 41p. Dissertação (Mestrado) - Faculdade de Ciências Agrárias e Veterinárias, Universidade Estadual Paulista “Júlio Mesquita de Mesquita”.

MEDEIROS, J.F. de. Qualidade da água de irrigação e evolução da salinidade nas propriedades assistidas pelo “GAT” nos Estados do RN, PB e CE. Campina Grande, 1992. 173p. Dissertação (Mestrado) - Universidade Federal da Paraíba.

MEDEIROS, J.F de. Manejo da água de irrigação salina em estufa cultivada com pimentão. Piracicaba, 1998. 152p. Tese (Doutorado) - Escola Superior de Agricultura Luiz de Queiroz, Universidade de São Paulo.

MEDEIROS, J.F. de; GHEYI, H.R. Manejo do sistema solo-água-planta em solos afetados por sais. In: GHEYI, H.R.; QUEIROZ, J.E.; MEDEIROS, J.F. de. (Ed.). Manejo e controle da salinidade na agricultura irrigada. Campina Grande: UFPB; SBEA, 1997. cap.8, p. 239-284.

MEDEIROS, J.F. de; CRUCIANI, E.D.; FOLEGATTI, M.V. Manejo, monitoramento e controle da salinidade em áreas de estufa. Piracicaba: ESALQ, Departamento de Engenharia Rural, 1996. 28p.

MEIRI, A.; PLAUT, Z.; PINKAS, L. Salt tolerance of glasshouse-grown muskmelon (cv. Galia). Soil Science, v.131, p.189-193, 1981.

MEIRI, A.; HOFFMAN, G.J.; SHANNON, M.C.; POSS, J.A. Salt tolerance of two muskmelon cultivars under two radiation levels. Journal of the American Sciety Hoticultural Science, v.107, p.1168-1172, 1982. 
MENDLINGER, S. Effect of increasing plant density and salinity on yield and fruit quality in muskmelon. Scientia Horticulturae, v.57, p.41-49, 1994.

MENEZES, J.B. Qualidade pós-colheita de melão tipo “Galia” durante a maturação e o armazenamento. Lavras, 1996. 87p. Tese (Doutorado) - Universidade Federal de Lavras.

MONTAG, U.J.; SHNEK, M. Principles of fertigation and their potential for global application: http://www.fertilizer.org/PUBLISH/PUBENV/fertigb8.htm. (16 maio 2003).

NERSON, H.; PARIS, H.S. Efects of salinity on germination, seedling growth, and yield of melons. Irrigation Science, v.5, p.265-273, 1984.

NICOLAS, M.Z. El melon. Madrid: Mundi Prensa, 1989. 174 p.

NUKAYA, A.M; MASUI, A.; ISHIDA, A. Salt tolerance of muskmelons grown in different salinity soils. Journal of Japanese Society for Horticultural Science, v.48, p.468-474, 1980.

OLIVEIRA, A.S.; SALATI, E. Um estudo sobre as água subterrâneas da região de Piracicaba. Anais da Escola Superior de Agricultura “Luiz de Queiroz”, v.38, p.163-190, 1981.

OLIVEIRA, M. Gênese, classificação e extensão de solos afetados por sais. In: GHEYI, H.R.; QUEIROZ, J.E.; MEDEIROS, J.F. de (Ed.). Manejo e controle da salinidade na agricultura irrigada. Campina Grande: UFPB; SBEA, 1997. cap.1, p. 1-35.

PADILLA, W.A. Lo que usted saber del suelo su análisis e interpretación para fertirrigación. Quito: Universidad Agraria del Ecuador, 1998. 121p. 
PAPADOPOULOS, I. Fertirrigação: situação atual e perspectivas para o futuro. In: FOLEGATTI, M.V. (Ed.). Fertirrigação: citrus, flores, hortaliças. Guaíba: Agropecuária, 1999. p.11-84.

PEDROSA, J. F. Cultivo do meloeiro. Mossoró: ESAM, Departamento de Engenharia Agrícola, 1997. 50p (Apostila).

PEREIRA, F.M.A.; MEDINA, B.F.; ETCHEVERS, J.D.; GHEYI, H.R. Solos afetados por sais no Nordeste I : efeito da relação solo-água nos valores de condutividade elétrica. Agropecuária Técnica, v.2. p.148-154, 1981.

PINTO, J.M. Aplicação de dióxido de carbono via água de irrigação em meloeiro. Piracicaba, 1997. 82p. Tese (Doutorado) - Escola Superior de Agricultura "Luiz de Queiroz”, Universidade de São Paulo.

PINTO, J. M.; SOARES, J.M.; PEREIRA, J.R.; COSTA, N.D.; BRITO, L.T.L. Sistema de cultivo de melão com aplicação de fertilização via água de irrigação. Petrolina: EMBRAPA, 1996. 24p. (Circular Técnica, 36).

PIZARRO, F. Drenaje agrícola y recuperación de suelos salinos. Madrid: Ed. Agrícola Española, 1978. 521p.

PRABHAKAR, B.S.; SRINIVAS, K.; SHUKLA, V. Yield and quality of muskmelon (cv. Hara madhu) in relation to spacing and fertilization. Progressive Horticulture, v.17, n.1, p.51-55, 1985.

QUEIROZ, J.E.; GONÇALVES, A.C.; SOUTO, J.S.; FOLEGATTI, M.V. Avaliação e monitoramento da salinidade do solo. In: GHEYI, H.R.; QUEIROZ, J.E; MEDEIROS, J.F. (Ed.). Manejo e controle da salinidade na agricultura irrigada. Campina Grande: UFPB; SBEA. 1997. cap.3, p.69-111.

RHOADES, J.D. Quality of water for irrigation. Soil Science, v.113, n.4, p.277-284, 1972. 
RHOADES, J.D. Eletrical conductivity methods for measuring and mapping soil salinity. Advances in Agronomy, v. 49. p.201-251, 1994.

RHOADES, J.D.; MIYAMOTO, S. Testing soils for salinity and sodicity. In: WESTERMAN, R.L. (Ed.). Soil testing and plant analysis. 3.ed. Madison: SSSA., 1990. cap. 12, p.299-336. (SSSA Book Series, 3).

RHOADES, J.D.; KANDIAH, A.; MASHALI, A.M. The use of saline waters for crop prodiction. Rome: FAO, 1992. 133p. (FAO Irrigation and Drainagem Paper, 48).

RICHARDS, L.A. Filter funnels for soil extracts. Agronomy Journal, v.41, p.446, 1949.

RICHARDS, L.A. Diagnosis and improvement of saline and alkali soils. Washington: United States Salinity Laboratory, 1954. 160p. (USDA. Agriculture Handbook, 60).

RICHARDS, L.A. Diagnostico y rehabilitacion de suelos salinos y sodicos. Mexico: Aid, 1970. 172p.

RICHARDSON, N.S.G.; MCCREE, K.J. Carbon balance and water relations of sorghum exposed to salt and water stress. Plant Physiology, v.79, p.1015-1020, 1985.

RIZZO, A.A.N.; QUIJANO, F.G.; LAURA, V.A. Efeito da idade de mudas no desenvolvimento do melão rendilhado. Horticultura Brasileira, v.18, p.468-469, 2000.

SANTOS, E.C. dos. Efeito do cloreto de sódio na germinação de sementes e no desenvolvimento inicial do mamoeiro. Mossoró, 2000. 35p. Monografia (Graduação) - Escola Superior de Agricultura de Mossoró. 
SANTOS, J.G.R. dos. Desenvolvimento e produção da bananeira nanica sob diferentes níveis de salinidade e lâminas de água. Campina Grande, 1997. 173p. Tese (Doutorado) - Universidade Federal da Paraíba.

SANTOS, R.N.C. Avaliação da relação K:N e híbridos de melão em cultivo hidropônico. Piracicaba, 2002. 98p. Dissertação (Mestrado) - Escola Superior de Agricultura “Luiz de Queiroz”, Universidade de São Paulo.

SENA, L.C.N.; GURGEL, F.L.; PEDROSA, J.F.; NEGREIROS, M.Z.; Comportamento de híbridos de melão tipo amarelo no município de Mossoró. Horticultura Brasileira, v. 18, supl., p.669-670, 2000.

SENTELHAS, P.C. Estimativa diária da evapotranspiração de referência com dados de estação meteorológica convencional e automática. Piracicaba, 1998. 97p. Tese (Doutorado) - Escola Superior de Agricultura “Luiz de Queiroz”, Universidade de São Paulo.

SHANNON, M.C.; FRANÇOIS, L.E. Salt tolerance of three muskmelon cultivars. Jounal of the American Society for Horticultural Science, v.103, p.127-130, 1978.

SHANNON, M.C. In quest of rapid screening techniques for plant salt tolerance. Scientia Horticulturae, v.14, n.5, p.587-589, 1979.

SILVA, E.F.F. Manejo da fertirrigação e controle da salinidade na cultura do pimentão utilizando extratores de solução do solo. Piracicaba. 2002. 136p. Tese (Doutorado) Escola Superior de Agricultura “Luiz de Queiroz”, Universidade de São Paulo.

SILVA, E.F.F; DUARTE, S.N.; COELHO, R.D. Salinização dos solos cultivados sob ambiente protegidos no Estado de São Paulo. In: FOLEGATTI, M.V. (Ed.). Fertirrigação: citrus, flores e hortaliças. Guaíba: Agropecuária, 1999. p.267-277. 
SILVEIRA, C.C da. Avaliação da salinidade dentro do bulbo úmido na cultura do melão. Mossoró. 1999. 34p. Monografia (Graduação). - Escola Superior de Agricultura de Mossoró.

SOARES, A.J. Efeitos de três lâminas de irrigação e de quatro doses de potássio via fertirrigação no meloeiro em ambiente protegido. Piracicaba, 2001. 63p. Dissertação (Mestrado) - Escola Superior de Agricultura “Luiz de Queiroz”, Universidade de São Paulo.

SOUSA, V.F. de; COELHO, E.F.; SOUSA, V.A.B. Freqüência de irrigação em meloeiro cultivado em solo arenoso. Pesquisa Agropecuária Brasileira, v.34, n.4, p.659664, 1999.

SOUSA, V. F. de; COELHO, E. F.; BASTOS, E.A.; FOLEGATTI, M.V.; FRIZZONE, J.A. Doses de nitrogênio e potássio por fertirrigação na produção do meloeiro. In: BALBUENA, R.H.; BENEZ, S.H.; JORAJURIA, D. (Ed.). Avances en el manejo del suelo y agua en la ingenieria rural latinoamericana. La Plata: Ed. UNLP, 1998. p.195-200.

SOUZA, M.R. Comportamento do feijoeiro (Phaseolus vulgaris L. CV Eriparza) submetido a diferentes níveis de salinidade da água de irrigação: Lavras, 1995. 94p. Dissertação (Mestrado) - Universidade Federal de Lavras.

STANGHELLINI, C. Evapotranspiration in greenhouse with special reference to mediterranean conditions. Acta Horticulturae, n.335, p.296-304, 1993.

TAL, M. Genetics of salt tolerance in higher plants: Theoretical and practical considerations. Plant and Soil, v.89, p.199-226, 1985.

VALE, M.F.S. Poda e densidade de plantio em híbridos de melão: Mossoró, 2000. 41p. Dissertação (Mestrado) - Escola Superior de Agricultura de Mossoró. 
VÁSQUEZ, M.A.N. Fertirrigação por gotejamento superficial e subsuperficial no meloeiro (Cucumis melo L.) sob condições protegidas. Piracicaba. 2003. 152 p. Tese (Doutorado) - Escola Superior de Agricultura “Luiz de Queiroz”, Universidade de São Paulo.

VILLAS BÔAS, R.L.; BOARETO, A.E.; VITTI, G.C. Aspectos da fertirrigação. In: VITTI, G.C.; BOARETO, A.E. (Ed.). Fertilizantes fluídos. Piracicaba: PATAFOS, 1994. cap.15, p. 283-308.

VILLAS BÔAS, R.L.; ANTUNES, C.L.; BOARETO, A.E.; SOUZA, V.F.de; DUENHAS, L.H. Perfil da pesquisa e emprego da fertirrigação no Brasil. In: FOLEGATTI, M.V.; CASARINI, E.; BLANCO, F.F.; BRASIL, R.P.C.; RESENDE, R.S. (Ed.). Fertirrigação: flores, frutas e hortaliças. Guaíba: Agropecuária, 2001. v.2, p.71-103.

WELLES, G.W.H.; BUITELAAR, K. Factors affecting soluble solids content of muskmelon (Cucumis melo L.). Netherlands Journal of Agricultural Science, v.36, p.239-246, 1988.

ZAPATA, M.N.; CABRERA, P.F.; BANÕN, S.A. El melon. Madrid: Mundi Prensa, 1989. 174p. 


\section{APÊNDICES}


APÊNDICE 1 - Tipos e quantidade de sais aplicados ao solo para obter os níveis de salinidade desejados

\begin{tabular}{|c|c|c|c|c|c|c|}
\hline \multirow{2}{*}{$\begin{array}{c}C E_{\mathrm{es}} \\
\left(\mathrm{dS} \mathrm{m} \mathrm{m}^{-1}\right)\end{array}$} & \multicolumn{5}{|c|}{ Concentração de sais $\left(\mathrm{mg} \mathrm{L}^{-1}\right)$} & \multirow{2}{*}{ Soma } \\
\hline & $\mathrm{NH}_{4} \mathrm{NO}_{3}$ & $\mathrm{KCl}$ & $\mathrm{H}_{3} \mathrm{PO}_{4}$ & $\mathrm{MgSO}_{4}$ & $\mathrm{Ca}\left(\mathrm{NO}_{3}\right)_{2}$ & \\
\hline 1 & 44,92 & 175,26 & 50,87 & 270,64 & 444,57 & 986,29 \\
\hline 2 & 109,98 & 429,13 & 124,56 & 662,66 & 1088,50 & 2414,86 \\
\hline 3 & 175,05 & 682,99 & 198,25 & 1054,67 & 1732,44 & 3843,43 \\
\hline 4 & 240,12 & 936,86 & 271,94 & 1446,68 & 2376,38 & 5272,00 \\
\hline 5 & 305,18 & 1190,72 & 345,63 & 1838,70 & 3020,31 & 6700,57 \\
\hline 6 & 370,25 & 1444,59 & 419,32 & 2230,71 & 3664,25 & 8129,14 \\
\hline
\end{tabular}


APÊNDICE 2 - Parecer Fitossanitário

CULTURA: melão rendilhado, cv.Bônus 2.

LOCAL: Departamento de Engenharia Rural da ESALQ-USP (06/02/2004)

PARECER: Candido Athayde Sobrinho

\section{ANTECEDENTES:}

Trata-se de uma área experimental, conduzida sob estufa e utilizada experimentalmente em um ensaio de avaliação de níveis de salinidade sobre o desenvolvimento e rendimento do meloeiro. O cultivo vem sendo implementado sob criterioso acompanhamento técnico. Durante a inspeção, observaram-se em algumas plantas, intensas alterações como murcha, seca e morte iminente de algumas delas, as quais foram coletadas para ulterior processamento laboratorial.

\section{QUEIXA PRINCIPAL:}

- Subdesenvolvimento, amarelecimento das plantas e murcha seguida de morte OBSERVAÇÕES EFETUADAS "IN SITU"

- Sistema radicular: Raízes primárias e secundárias apresentando galhas ou tumores radiculares

- Colo/caule: Estruturas morfológicas externas anatomicamente preservadas.

- Ramos secundários: Idem.

- Flores e frutos: Idem

OBSERVAÇÕES LABORATORIAIS EFETUADAS-

- Folhas: Após análise e dissecação do material coletado (folhas), constataram-se distúrbios de duas formas: Amarelecimento e seca (Figura A1). Não foi identificada presença de fitopatógenos nem de artrópodes-praga sobre o material examinado

- Raízes: Presença de "nematogalhas”, sendo observado no interior das mesmas, presença de fêmeas de nematóides e intensa desagregação dos feixes vasculares, cambio e parênquima (Figura B1). Análise do modelo perineal de fêmeas adultas (Figura B2), sugere colonização de nematóides pertencente a espécie Meloidogyne javanica. 


\section{CONCLUSÃO}

Exame POSITIVO para fitonematóides, da espécie M. Javanica. RECOMENDAÇÃO

Em virtude da cultura se encontrar em fase final de ciclo, não se faz necessário controle do nematóide. Recomenda-se para o próximo plantio, tratamento do solo com produtos erradicantes.

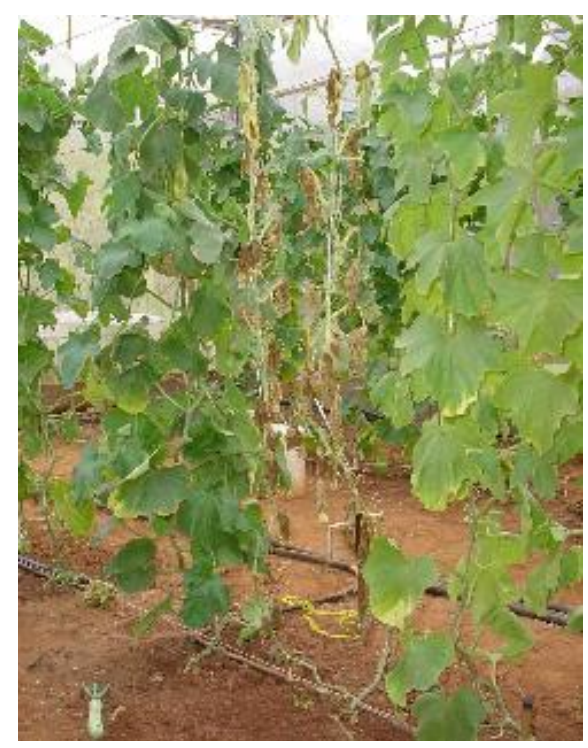

Figura A - Parcela apresentando planta com sintoma de seca nas folhas

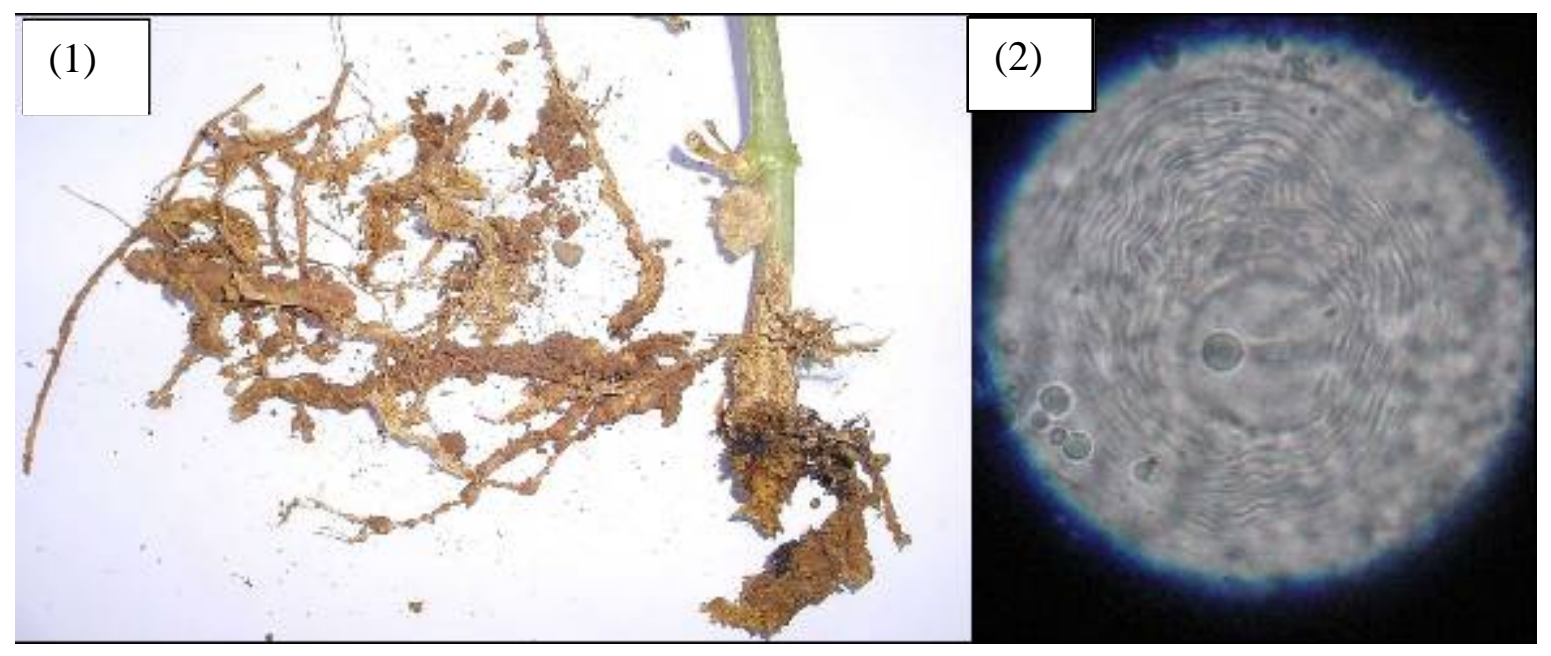

Figura B - Base do caule e raízes apresentado tumores radiculares (1); detalhe do contorno perineal de uma fêmea de $M$. javanica (2) 
APÊNDICE 3 - Quantidade de nutrientes (g planta ${ }^{-1}$ ) aplicados nas irrigações para o manejo tradicional e para os diferentes níveis de salinidade do manejo controlado da fertirrigação ao longo do primeiro ciclo

\begin{tabular}{|c|c|c|c|c|c|}
\hline \multirow{2}{*}{ Nutrientes } & \multicolumn{5}{|c|}{ Intervalos de dias após a semeadura } \\
\hline & $0-29$ & $30-44$ & $45-59$ & $60-85$ & Total \\
\hline & \multicolumn{5}{|c|}{ Manejo Tradicional $-\mathrm{M}_{1}$} \\
\hline $\mathrm{N}$ & 0,169 & 1,327 & 2,540 & 2,270 & 6,306 \\
\hline $\mathrm{P}$ & 0,035 & 0,204 & 0,483 & 0,894 & 1,617 \\
\hline $\mathrm{K}$ & 0,119 & 1,229 & 2,175 & 2,419 & 5,942 \\
\hline $\mathrm{Ca}$ & 0,069 & 0,913 & 1,499 & 2,047 & 4,528 \\
\hline \multirow[t]{2}{*}{$\mathrm{Mg}$} & 0,069 & 0,223 & 0,603 & 1,066 & 1,962 \\
\hline & \multicolumn{5}{|c|}{$\frac{\text { Manejo Controlado }-\mathrm{M}_{2}}{\mathrm{~S}=1 \mathrm{dS} \mathrm{m}^{-1}}$} \\
\hline $\mathrm{N}$ & 0,191 & 1,097 & 1,167 & 1,600 & 4,055 \\
\hline $\mathrm{P}$ & 0,040 & 0,130 & 0,222 & 0,416 & 0,807 \\
\hline $\mathrm{K}$ & 0,134 & 0,780 & 0,999 & 1,141 & 3,054 \\
\hline $\mathrm{Ca}$ & 0,078 & 0,580 & 0,689 & 0,952 & 2,298 \\
\hline Mg & 0,078 & \multicolumn{3}{|c|}{$\mathrm{S}=2 \mathrm{dS} \mathrm{m}^{-1}$} & 0,993 \\
\hline $\mathrm{N}$ & 0,191 & 1,779 & 3,208 & 1,600 & 6,778 \\
\hline $\mathrm{P}$ & 0,040 & 0,210 & 0,609 & 0,416 & 1,275 \\
\hline $\mathrm{K}$ & 0,134 & 1,265 & 2,746 & 1,141 & 5,2862 \\
\hline $\mathrm{Ca}$ & 0,078 & 0,940 & 1,893 & 0,952 & 3,862 \\
\hline Mg & 0,078 & \multicolumn{3}{|c|}{$\mathrm{S}=3 \mathrm{dS} \mathrm{m}^{-1}$} & 1,565 \\
\hline $\mathrm{N}$ & 0,191 & 1,779 & 2,540 & 1,926 & 6,436 \\
\hline $\mathrm{P}$ & 0,040 & 0,210 & 0,483 & 0,501 & 1,233 \\
\hline $\mathrm{K}$ & 0,134 & 1,265 & 2,175 & 1,351 & 4,925 \\
\hline $\mathrm{Ca}$ & 0,078 & 0,940 & 1,499 & 1,146 & 3,663 \\
\hline $\mathrm{Mg}$ & \multicolumn{4}{|c|}{$\mathrm{S}=4 \mathrm{dS} \mathrm{m}^{-1}$} & 1,508 \\
\hline $\mathrm{N}$ & 0,191 & 2,505 & 4,217 & 3,440 & 10,353 \\
\hline $\mathrm{P}$ & 0,040 & 0,296 & 0,801 & 0,894 & 2,031 \\
\hline $\mathrm{K}$ & 0,134 & 1,780 & 3,611 & 2,556 & 8,081 \\
\hline $\mathrm{Ca}$ & 0,078 & 1,324 & 2,488 & 2,047 & 5,936 \\
\hline $\mathrm{Mg}$ & 0,078 & \multicolumn{3}{|c|}{$\mathrm{S}=5 \mathrm{dS} \mathrm{m}^{-1}$} & 2,469 \\
\hline $\mathrm{N}$ & 0,191 & 2,808 & 4,847 & 3,440 & 11,286 \\
\hline $\mathrm{P}$ & 0,040 & 0,332 & 0,921 & 0,894 & 2,187 \\
\hline $\mathrm{K}$ & 0,134 & 1,996 & 4,150 & 2,556 & 8,836 \\
\hline $\mathrm{Ca}$ & 0,078 & 1,484 & 2,860 & 2,047 & 6,468 \\
\hline $\mathrm{Mg}$ & 0,078 & 0,362 & \multicolumn{2}{|c|}{$\mathrm{S}=6 \mathrm{dS} \mathrm{m}^{-1}$} & 2,657 \\
\hline $\mathrm{N}$ & 0,191 & 2,889 & 16,406 & 3,440 & 22,926 \\
\hline $\mathrm{P}$ & 0,040 & 0,342 & 3,116 & 0,894 & 4,392 \\
\hline $\mathrm{K}$ & 0,134 & 2,054 & 14,046 & 2,556 & 18,791 \\
\hline $\mathrm{Ca}$ & 0,078 & 1,527 & 9,679 & 2,047 & 13,330 \\
\hline $\mathrm{Mg}$ & 0,078 & 0,372 & 3,896 & 1,066 & 5,413 \\
\hline
\end{tabular}


APÊNDICE 4 - Quantidade de nutrientes (g planta ${ }^{-1}$ ) aplicados nas irrigações para o manejo tradicional e para os diferentes níveis de salinidade do manejo controlado da fertirrigação ao longo do segundo ciclo

\begin{tabular}{|c|c|c|c|c|c|}
\hline \multirow{2}{*}{ Nutrientes } & \multicolumn{5}{|c|}{ Intervalos de dias após a semeadura } \\
\hline & $0-29$ & $30-44$ & $45-59$ & $60-85$ & Total \\
\hline & \multicolumn{5}{|c|}{ Manejo Tradicional $-\mathrm{M}_{1}$} \\
\hline $\mathrm{N}$ & 0,916 & 2,021 & 1,744 & 2,819 & 7,501 \\
\hline $\mathrm{P}$ & 0,191 & 0,239 & 0,331 & 0,733 & 1,494 \\
\hline K & 0,644 & 1,436 & 1,493 & 1,817 & 5,391 \\
\hline $\mathrm{Ca}$ & 0,374 & 1,068 & 1,029 & 1,677 & 4,148 \\
\hline \multirow[t]{2}{*}{ Mg } & 0,376 & 0,260 & 0,414 & 0,874 & 1,924 \\
\hline & \multicolumn{5}{|c|}{$\frac{\text { Manejo Controlado }-\mathrm{M}_{2}}{\mathrm{~S}=1 \mathrm{dS} \mathrm{m}^{-1}}$} \\
\hline $\mathrm{N}$ & 0,572 & 1,155 & 1,044 & 0,652 & 3,423 \\
\hline $\mathrm{P}$ & 0,119 & 0,137 & 0,198 & 0,170 & 0,623 \\
\hline $\mathrm{K}$ & 0,402 & 0,821 & 0,894 & 0,421 & 2,537 \\
\hline $\mathrm{Ca}$ & 0,233 & 0,610 & 0,616 & 0,388 & 1,848 \\
\hline Mg & \multicolumn{5}{|c|}{$\mathrm{S}=2 \mathrm{dS} \mathrm{m}^{-1}$} \\
\hline $\mathrm{N}$ & 0,572 & 1,155 & 1,044 & 1,157 & 3,928 \\
\hline $\mathrm{P}$ & 0,119 & 0,137 & 0,198 & 0,301 & 0,755 \\
\hline $\mathrm{K}$ & 0,402 & 0,821 & 0,894 & 0,746 & 2,862 \\
\hline $\mathrm{Ca}$ & 0,233 & 0,610 & 0,616 & 0,689 & 2,148 \\
\hline $\mathrm{Mg}$ & 0,234 & \multicolumn{3}{|c|}{$\mathrm{S}=3 \mathrm{dS} \mathrm{m}^{-1}$} & 0,990 \\
\hline $\mathrm{N}$ & 0,572 & 2,021 & 1,744 & 2,819 & 7,156 \\
\hline $\mathrm{P}$ & 0,119 & 0,239 & 0,331 & 0,733 & 1,422 \\
\hline $\mathrm{K}$ & 0,402 & 1,436 & 1,493 & 1,817 & 5,149 \\
\hline $\mathrm{Ca}$ & 0,233 & 1,068 & 1,029 & 1,677 & 4,008 \\
\hline $\mathrm{Mg}$ & 0,234 & \multicolumn{3}{|c|}{$\mathrm{S}=4 \mathrm{dS} \mathrm{m}^{-1}$} & 1,783 \\
\hline $\mathrm{N}$ & 1,902 & 2,021 & 1,744 & 2,819 & 8,486 \\
\hline $\mathrm{P}$ & 0,396 & 0,239 & 0,331 & 0,733 & 1,699 \\
\hline $\mathrm{K}$ & 1,337 & 1,436 & 1,493 & 1,817 & 6,084 \\
\hline $\mathrm{Ca}$ & 0,776 & 1,068 & 1,029 & 1,677 & 4,550 \\
\hline Mg & 0,780 & 0,260 & $\begin{array}{c}0,414 \\
S=5 \mathrm{dS} \mathrm{m}^{-1}\end{array}$ & 0,874 & 2,328 \\
\hline $\mathrm{N}$ & 0,916 & 2,021 & 2,362 & 2,819 & 8,118 \\
\hline $\mathrm{P}$ & 0,191 & 0,239 & 0,449 & 0,733 & 1,611 \\
\hline $\mathrm{K}$ & 0,644 & 1,436 & 2,023 & 1,817 & 5,920 \\
\hline $\mathrm{Ca}$ & 0,374 & 1,068 & 1,394 & 1,677 & 4,513 \\
\hline $\mathrm{Mg}$ & \multicolumn{5}{|c|}{$\mathrm{S}=6 \mathrm{dS} \mathrm{m}^{-1}$} \\
\hline $\mathrm{N}$ & 2,271 & 2,021 & 1,744 & 2,819 & 8,856 \\
\hline $\mathrm{P}$ & 0,472 & 0,239 & 0,331 & 0,733 & 1,776 \\
\hline K & 1,597 & 1,436 & 1,493 & 1,817 & 6,344 \\
\hline $\mathrm{Ca}$ & 0,927 & 1,068 & 1,029 & 1,677 & 4,701 \\
\hline $\mathrm{Mg}$ & 0,931 & 0,260 & 0,414 & 0,874 & 2,480 \\
\hline
\end{tabular}


APÊNDICE 5 - Caracterização química do solo após a salinização artificial do solo realizada no início do transplantio do primeiro ciclo do meloeiro

\begin{tabular}{cccccccc}
\hline \multirow{2}{*}{ Tratamentos } & $\begin{array}{c}\mathrm{pH} \\
\mathrm{CaCl}_{2}\end{array}$ & $\begin{array}{c}\mathrm{MO} \\
\ldots . . \mathrm{mg} \mathrm{dcm}^{-3} \ldots . .\end{array}$ & $\begin{array}{c}\mathrm{P} \\
\mathrm{K}^{+}\end{array}$ & $\mathrm{Ca}^{2+}$ & $\mathrm{Mg}^{2+}$ & $\mathrm{SB}$ \\
& 4,3 & 12 & 31 & 3,2 & 9 & 5 & 17,2 \\
$\mathrm{~S}_{1}$ & 4,1 & 14 & 29 & 4,3 & 8 & 4 & 16,3 \\
$\mathrm{~S}_{2}$ & 4,2 & 12 & 42 & 4,8 & 10 & 5 & 19,8 \\
$\mathrm{~S}_{3}$ & 4,3 & 13 & 59 & 5,2 & 11 & 4 & 20,2 \\
$\mathrm{~S}_{4}$ & 4,3 & 12 & 96 & 6,2 & 13 & 5 & 24,2 \\
$\mathrm{~S}_{5}$ & 4,2 & 12 & 182 & 6,9 & 15 & 7 & 28,9 \\
$\mathrm{~S}_{6}$ & & & & & & & \\
\hline
\end{tabular}

APÊNDICE 6 - Caracterização química do solo aos 60 DAT do primeiro ciclo do meloeiro na camada de $0-20 \mathrm{~cm}$

\begin{tabular}{cccccccc}
\hline \multirow{2}{*}{ Tratamentos } & $\begin{array}{c}\mathrm{pH} \\
\mathrm{CaCl}\end{array}$ & \multicolumn{2}{c}{$\mathrm{MO}$} & $\begin{array}{c}\mathrm{P} \\
\mathrm{Camg} \mathrm{dcm}^{-3} \ldots . .\end{array}$ & \multicolumn{2}{c}{$\ldots \ldots \ldots \ldots \ldots \mathrm{Kmol}_{\mathrm{c}} \mathrm{dm}^{-3} \ldots \ldots \ldots \ldots$} \\
\hline $\mathrm{S}_{1} \mathrm{M}_{1}$ & 4,4 & 18 & 17 & 4,0 & 13 & 6 & 23,0 \\
$\mathrm{~S}_{1} \mathrm{M}_{2}$ & 4,3 & 14 & 12 & 3,9 & 11 & 5 & 19,9 \\
$\mathrm{~S}_{2} \mathrm{M}_{1}$ & 4,2 & 16 & 20 & 5,2 & 11 & 5 & 21,2 \\
$\mathrm{~S}_{2} \mathrm{M}_{2}$ & 4,1 & 14 & 48 & 5,4 & 12 & 5 & 22,4 \\
$\mathrm{~S}_{3} \mathrm{M}_{1}$ & 4,2 & 17 & 40 & 5,9 & 12 & 5 & 22,9 \\
$\mathrm{~S}_{3} \mathrm{M}_{2}$ & 4,2 & 14 & 64 & 6,0 & 15 & 8 & 29,0 \\
$\mathrm{~S}_{4} \mathrm{M}_{1}$ & 4,0 & 13 & 65 & 6,8 & 13 & 5 & 24,8 \\
$\mathrm{~S}_{4} \mathrm{M}_{2}$ & 4,1 & 11 & 75 & 7,2 & 18 & 7 & 32,2 \\
$\mathrm{~S}_{5} \mathrm{M}_{1}$ & 4,1 & 15 & 122 & 7,4 & 14 & 7 & 28,4 \\
$\mathrm{~S}_{5} \mathrm{M}_{2}$ & 4,2 & 13 & 122 & 7,0 & 16 & 6 & 29,0 \\
$\mathrm{~S}_{6} \mathrm{M}_{1}$ & 4,1 & 12 & 135 & 7,3 & 18 & 7 & 32,3 \\
$\mathrm{~S}_{6} \mathrm{M}_{2}$ & 4,1 & 14 & 108 & 7,5 & 13 & 5 & 25,5 \\
\hline
\end{tabular}


APÊNDICE 7 - Caracterização química do solo aos 90 DAT do primeiro ciclo do meloeiro, na camada de $0-20 \mathrm{~cm}$

\begin{tabular}{|c|c|c|c|c|c|c|c|}
\hline Tratamentos & $\begin{array}{c}\mathrm{pH} \\
\mathrm{CaCl}_{2}\end{array}$ & $\begin{array}{r}\mathrm{MO} \\
\ldots . . \mathrm{m}\end{array}$ & .....mg dcm ${ }^{-3} \ldots .$. & $\mathrm{K}^{+}$ & $\begin{array}{c}\mathrm{Ca}^{2+} \\
\ldots \ldots . .\end{array}$ & $\begin{array}{l}\mathrm{Mg}^{2+} \\
\mathrm{nol}_{\mathrm{C}} \mathrm{d}\end{array}$ & $\begin{array}{r}\text { SB } \\
\ldots \ldots\end{array}$ \\
\hline $\mathrm{S}_{1} \mathrm{M}_{1}$ & 4,3 & 14 & 16 & 5,9 & 13 & 6 & 25,9 \\
\hline $\mathrm{S}_{1} \mathrm{M}_{2}$ & 4,3 & 14 & 13 & 4,7 & 9 & 5 & 16,7 \\
\hline $\mathrm{S}_{2} \mathrm{M}_{1}$ & 4,2 & 13 & 17 & 5,8 & 9 & 5 & 18,8 \\
\hline $\mathrm{S}_{2} \mathrm{M}_{2}$ & 4,2 & 13 & 15 & 5,9 & 8 & 5 & 17,9 \\
\hline $\mathrm{S}_{3} \mathrm{M}_{1}$ & 4,1 & 11 & 35 & 6,0 & 7 & 5 & 16,0 \\
\hline $\mathrm{S}_{3} \mathrm{M}_{2}$ & 4,1 & 13 & 44 & 6,3 & 9 & 8 & 19,3 \\
\hline $\mathrm{S}_{4} \mathrm{M}_{1}$ & 4,1 & 12 & 91 & 6,8 & 6 & 5 & 15,8 \\
\hline $\mathrm{S}_{4} \mathrm{M}_{2}$ & 4,0 & 12 & 79 & 5,5 & 10 & 7 & 19,5 \\
\hline $\mathrm{S}_{5} \mathrm{M}_{1}$ & 4,1 & 11 & 140 & 7,3 & 8 & 7 & 18,3 \\
\hline $\mathrm{S}_{5} \mathrm{M}_{2}$ & 4,1 & 14 & 122 & 5,8 & 12 & 6 & 22,8 \\
\hline $\mathrm{S}_{6} \mathrm{M}_{1}$ & 4,1 & 12 & 144 & 6,5 & 9 & 7 & 19,5 \\
\hline $\mathrm{S}_{6} \mathrm{M}_{2}$ & 4,1 & 12 & 89 & 8,8 & 12 & 5 & 23,8 \\
\hline
\end{tabular}


APÊNDICE 8 - Caracterização química do solo aos 10 DAT do segundo ciclo do meloeiro, na camada de $0-20 \mathrm{~cm}$

\begin{tabular}{cccccccc}
\hline Tratamentos & $\begin{array}{c}\mathrm{pH} \\
\mathrm{CaCl}_{2}\end{array}$ & $\begin{array}{c}\mathrm{MO} \\
\ldots . \mathrm{mg}\end{array}$ & $\begin{array}{c}\mathrm{P} \\
\mathrm{dcm}^{-3} \ldots \ldots\end{array}$ & $\mathrm{K}^{+}$ & $\begin{array}{c}\mathrm{Ca}^{2+} \\
\ldots \ldots \ldots \ldots \ldots \mathrm{mmol}_{\mathrm{c}} \mathrm{dm}^{-3} \ldots \ldots \ldots \ldots .\end{array}$ \\
\hline $\mathrm{S}_{1} \mathrm{M}_{1}$ & 4,0 & 12 & 27 & 5,8 & 19 & 8 & 32,8 \\
$\mathrm{~S}_{1} \mathrm{M}_{2}$ & 4,2 & 13 & 12 & 4,3 & 9 & 5 & 18,3 \\
$\mathrm{~S}_{2} \mathrm{M}_{1}$ & 4,0 & 13 & 48 & 5,7 & 9 & 4 & 18,7 \\
$\mathrm{~S}_{2} \mathrm{M}_{2}$ & 4,1 & 13 & 21 & 5,0 & 10 & 5 & 20,0 \\
$\mathrm{~S}_{3} \mathrm{M}_{1}$ & 4,0 & 14 & 51 & 7,6 & 17 & 8 & 32,6 \\
$\mathrm{~S}_{3} \mathrm{M}_{2}$ & 4,1 & 12 & 73 & 5,7 & 12 & 8 & 23,7 \\
$\mathrm{~S}_{4} \mathrm{M}_{1}$ & 4,2 & 13 & 105 & 7,7 & 28 & 13 & 48,7 \\
$\mathrm{~S}_{4} \mathrm{M}_{2}$ & 4,1 & 11 & 41 & 6,7 & 16 & 7 & 29,7 \\
$\mathrm{~S}_{5} \mathrm{M}_{1}$ & 4,0 & 14 & 147 & 7,6 & 17 & 9 & 33,6 \\
$\mathrm{~S}_{5} \mathrm{M}_{2}$ & 4,1 & 13 & 130 & 7,2 & 26 & 10 & 43,2 \\
$\mathrm{~S}_{6} \mathrm{M}_{1}$ & 4,1 & 13 & 105 & 7,3 & 18 & 8 & 33,3 \\
$\mathrm{~S}_{6} \mathrm{M}_{2}$ & 4,1 & 15 & 121 & 8,4 & 26 & 12 & 46,4 \\
\hline
\end{tabular}

APÊNDICE 9 - Caracterização química do solo aos 45 DAT do segundo ciclo do meloeiro, na camada de $0-20 \mathrm{~cm}$

\begin{tabular}{|c|c|c|c|c|c|c|c|}
\hline Tratamentos & $\begin{array}{c}\mathrm{pH} \\
\mathrm{CaCl}_{2}\end{array}$ & \multicolumn{2}{|c|}{.....mg $\mathrm{dcm}^{-3} .}$. & $\mathrm{K}^{+}$ & $\begin{array}{c}\mathrm{Ca}^{2+} \\
\ldots . . . \\
\end{array}$ & $\begin{array}{l}\mathrm{Mg}^{2} \\
\mathrm{nol}_{\mathrm{C}} \mathrm{C}\end{array}$ & $\begin{array}{c}\text { SB } \\
\ldots . . . \\
\end{array}$ \\
\hline $\mathrm{S}_{1} \mathrm{M}_{1}$ & 4,1 & 13 & 27 & 6,2 & 9 & 4 & 19,2 \\
\hline $\mathrm{S}_{1} \mathrm{M}_{2}$ & 4,3 & 14 & 18 & 5,4 & 15 & 6 & 26,4 \\
\hline $\mathrm{S}_{2} \mathrm{M}_{1}$ & 4,1 & 11 & 67 & 6,1 & 14 & 5 & 25,1 \\
\hline $\mathrm{S}_{2} \mathrm{M}_{2}$ & 4,0 & 13 & 40 & 4,7 & 8 & 3 & 15,7 \\
\hline $\mathrm{S}_{3} \mathrm{M}_{1}$ & 4,0 & 10 & 67 & 5,6 & 10 & 4 & 19,6 \\
\hline $\mathrm{S}_{3} \mathrm{M}_{2}$ & 4,1 & 13 & 81 & 6,5 & 16 & 6 & 28,5 \\
\hline $\mathrm{S}_{4} \mathrm{M}_{1}$ & 4,0 & 12 & 62 & 6,0 & 10 & 4 & 20,0 \\
\hline $\mathrm{S}_{4} \mathrm{M}_{2}$ & 4,0 & 13 & 77 & 6,2 & 12 & 5 & 23,2 \\
\hline $\mathrm{S}_{5} \mathrm{M}_{1}$ & 4,0 & 14 & 88 & 6,5 & 13 & 6 & 25,5 \\
\hline $\mathrm{S}_{5} \mathrm{M}_{2}$ & 4,0 & 12 & 110 & 6,2 & 13 & 6 & 25,2 \\
\hline $\mathrm{S}_{6} \mathrm{M}_{1}$ & 4,0 & 14 & 158 & 5,8 & 14 & 5 & 24,8 \\
\hline $\mathrm{S}_{6} \mathrm{M}_{2}$ & 4,0 & 12 & 162 & 5,8 & 14 & 4 & 23,8 \\
\hline
\end{tabular}


APÊNDICE 10 - Caracterização química do solo aos 90 DAT do segundo ciclo do meloeiro, na camada de $0-20 \mathrm{~cm}$

\begin{tabular}{cccccccc}
\hline \multirow{2}{*}{ Tratamentos } & $\begin{array}{c}\mathrm{pH} \\
\mathrm{CaCl}_{2}\end{array}$ & \multicolumn{2}{c}{$\mathrm{MO}$} & $\begin{array}{c}\mathrm{P} \\
\mathrm{mg} \mathrm{dcm}^{-3} \ldots . .\end{array}$ & \multicolumn{2}{c}{$\ldots \ldots \ldots \ldots \ldots \mathrm{Kmol}_{\mathrm{c}} \mathrm{dm}^{-3} \ldots \ldots \ldots \ldots$} \\
\hline $\mathrm{S}_{1} \mathrm{M}_{1}$ & 4,0 & 14 & 94 & 5,2 & 14 & 5 & 24,2 \\
$\mathrm{~S}_{1} \mathrm{M}_{2}$ & 4,0 & 16 & 74 & 5,6 & 13 & 6 & 24,6 \\
$\mathrm{~S}_{2} \mathrm{M}_{1}$ & 4,0 & 14 & 105 & 6,4 & 13 & 5 & 24,4 \\
$\mathrm{~S}_{2} \mathrm{M}_{2}$ & 4,0 & 10 & 90 & 5,3 & 10 & 5 & 20,3 \\
$\mathrm{~S}_{3} \mathrm{M}_{1}$ & 3,8 & 13 & 133 & 6,3 & 14 & 6 & 26,3 \\
$\mathrm{~S}_{3} \mathrm{M}_{2}$ & 3,9 & 12 & 168 & 6,6 & 19 & 6 & 31,6 \\
$\mathrm{~S}_{4} \mathrm{M}_{1}$ & 3,8 & 12 & 150 & 6,2 & 15 & 6 & 27,2 \\
$\mathrm{~S}_{4} \mathrm{M}_{2}$ & 3,9 & 13 & 234 & 7,2 & 21 & 10 & 38,2 \\
$\mathrm{~S}_{5} \mathrm{M}_{1}$ & 3,8 & 12 & 161 & 6,1 & 15 & 7 & 28,1 \\
$\mathrm{~S}_{5} \mathrm{M}_{2}$ & 3,8 & 13 & 279 & 5,5 & 12 & 5 & 22,5 \\
$\mathrm{~S}_{6} \mathrm{M}_{1}$ & 3,8 & 15 & 245 & 6,4 & 13 & 5 & 24,4 \\
$\mathrm{~S}_{6} \mathrm{M}_{2}$ & 4,0 & 12 & 182 & 6,8 & 14 & 6 & 26,8 \\
\hline
\end{tabular}


APÊNDICE 11 - Lâmina média diária e acumulada de água aplicada, por época de aplicação para os diferentes níveis de salinidade e manejo da fertirrigação durante o primeiro ciclo

\begin{tabular}{|c|c|c|c|c|c|c|c|c|}
\hline \multirow{3}{*}{ 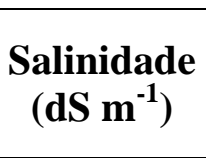 } & \multicolumn{8}{|c|}{ Intervalo de dias após o transplantio } \\
\hline & \multicolumn{2}{|c|}{ 1-30 } & \multicolumn{2}{|c|}{$31-60$} & \multicolumn{2}{|c|}{ 61-90 } & \multicolumn{2}{|c|}{ 91-117 } \\
\hline & Diária & Acum & Diária & Acum & Diária & Acum & Diária & Acum \\
\hline & \multicolumn{8}{|c|}{ Manejo Tradicional - $\mathrm{M}_{1}$} \\
\hline 1 & 4,20 & 32,49 & 3,38 & 101,24 & 4,59 & 202,25 & 5,69 & 321,78 \\
\hline 2 & 4,20 & 32,49 & 3,61 & 103,68 & 4,42 & 207,68 & 5,04 & 312,79 \\
\hline 3 & 4,20 & 32,49 & 3,98 & 106,96 & 4,52 & 221,19 & 5,28 & 326,47 \\
\hline 4 & 4,20 & 32,49 & 3,69 & 104,46 & 4,53 & 211,42 & 5,51 & 323,20 \\
\hline 5 & 4,20 & 32,49 & 3,49 & 101,27 & 4,44 & 211,43 & 5,04 & 311,33 \\
\hline \multirow[t]{2}{*}{6} & 4,20 & 32,49 & 3,71 & 104,17 & 4,81 & 219,24 & 4,86 & 323,87 \\
\hline & \multicolumn{8}{|c|}{ Manejo Controlado - $\mathrm{M}_{2}$} \\
\hline 1 & 4,20 & 32,49 & 3,64 & 104,28 & 5,17 & 220,57 & 5,97 & 344,80 \\
\hline 2 & 4,20 & 32,49 & 4,21 & 110,57 & 5,31 & 237,60 & 6,15 & 364,66 \\
\hline 3 & 4,20 & 32,49 & 4,33 & 112,56 & 5,13 & 238,27 & 5,46 & 352,19 \\
\hline 4 & 4,20 & 32,49 & 4,61 & 114,78 & 5,31 & 248,17 & 5,88 & 370,47 \\
\hline 5 & 4,20 & 32,49 & 3,99 & 107,58 & 4,76 & 225,14 & 4,86 & 329,31 \\
\hline 6 & 4,20 & 32,49 & 3,75 & 105,53 & 4,18 & 209,65 & 5,04 & 311,12 \\
\hline
\end{tabular}

APÊNDICE 12 - Lâmina média diária e acumulada de água aplicada, por época de aplicação, para os diferentes níveis de salinidade e manejo da fertirrigação durante o segundo ciclo

\begin{tabular}{|c|c|c|c|c|c|c|c|c|}
\hline \multirow{3}{*}{$\begin{array}{c}\text { Salinidade } \\
\left(\mathbf{d S} \mathrm{m}^{-1}\right)\end{array}$} & \multicolumn{8}{|c|}{ Intervalo de dias após o transplantio } \\
\hline & \multicolumn{2}{|c|}{$1-22$} & \multicolumn{2}{|c|}{$23-45$} & \multicolumn{2}{|c|}{ 46-68 } & \multicolumn{2}{|c|}{ 69-93 } \\
\hline & Diária & Acum & Diária & Acum & Diária & Acum & Diária & Acum \\
\hline & \multicolumn{8}{|c|}{ Manejo Tradicional $-\mathrm{M}_{1}$} \\
\hline 1 & 3,29 & 28,40 & 3,61 & 92,04 & 3,64 & 156,28 & 3,08 & 206,47 \\
\hline 2 & 3,50 & 29,55 & 3,84 & 94,44 & 4,01 & 166,98 & 4,50 & 229,43 \\
\hline 3 & 3,08 & 26,42 & 4,58 & 100,83 & 3,47 & 164,76 & 4,26 & 222,64 \\
\hline 4 & 3,25 & 28,15 & 5,28 & 110,28 & 3,68 & 181,47 & 3,89 & 238,69 \\
\hline 5 & 3,21 & 27,33 & 4,30 & 102,59 & 3,39 & 161,30 & 3,33 & 211,90 \\
\hline \multirow[t]{2}{*}{6} & 3,37 & 28,48 & 4,90 & 108,43 & 3,64 & 176,86 & 3,33 & 229,19 \\
\hline & \multicolumn{8}{|c|}{ Manejo Controlado - $\mathrm{M}_{2}$} \\
\hline 1 & 3,62 & 30,70 & 4,35 & 106,48 & 4,42 & 184,26 & 4,63 & 250,17 \\
\hline 2 & 3,50 & 29,55 & 6,48 & 124,81 & 5,03 & 223,28 & 4,63 & 292,89 \\
\hline 3 & 3,25 & 27,57 & 5,83 & 114,91 & 3,88 & 195,62 & 3,38 & 246,10 \\
\hline 4 & 3,50 & 29,63 & 6,06 & 119,07 & 3,68 & 199,82 & 4,69 & 261,41 \\
\hline 5 & 2,80 & 23,87 & 3,42 & 82,87 & 3,59 & 142,86 & 3,15 & 191,41 \\
\hline 6 & 3,29 & 27,49 & 3,98 & 96,94 & 3,31 & 156,94 & 3,21 & 205,36 \\
\hline
\end{tabular}

